\title{
INVESTIGATION OF LOW-TEMPERATURE GEOTHERMAL RESOURCES IN THE SONOMA VALLEY AREA, CALIFORNIA
}

\author{
1983
}

\section{CALIFORNIA DEPARTMENT OF CONSERVATION DIVISION OF MINES AND GEOLOGY}

This work was performed under Grant No. DE-FG03-81SF10855 for the U.S. Department of Energy, Division of Geothermal Energy, by the California Department of Conservation, Division of Mines and Geology.

OPEN FILE REPORT 83-13 SAC

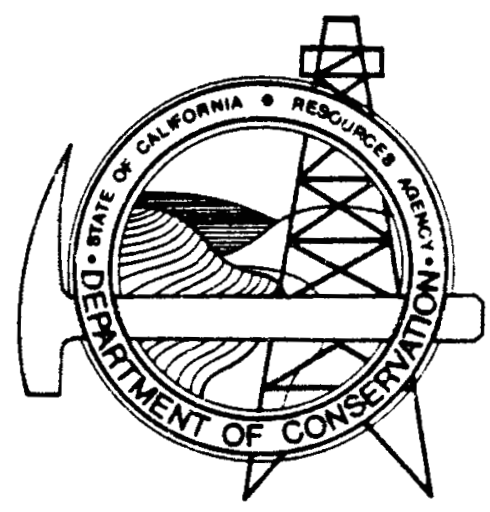




\section{DISCLAIMER}

This report was prepared as an account of work sponsored by an agency of the United States Government. Neither the United States Government nor any agency Thereof, nor any of their employees, makes any warranty, express or implied, or assumes any legal liability or responsibility for the accuracy, completeness, or usefulness of any information, apparatus, product, or process disclosed, or represents that its use would not infringe privately owned rights. Reference herein to any specific commercial product, process, or service by trade name, trademark, manufacturer, or otherwise does not necessarily constitute or imply its endorsement, recommendation, or favoring by the United States Government or any agency thereof. The views and opinions of authors expressed herein do not necessarily state or reflect those of the United States Government or any agency thereof. 


\section{DISCLAIMER}

Portions of this document may be illegible in electronic image products. Images are produced from the best available original document. 

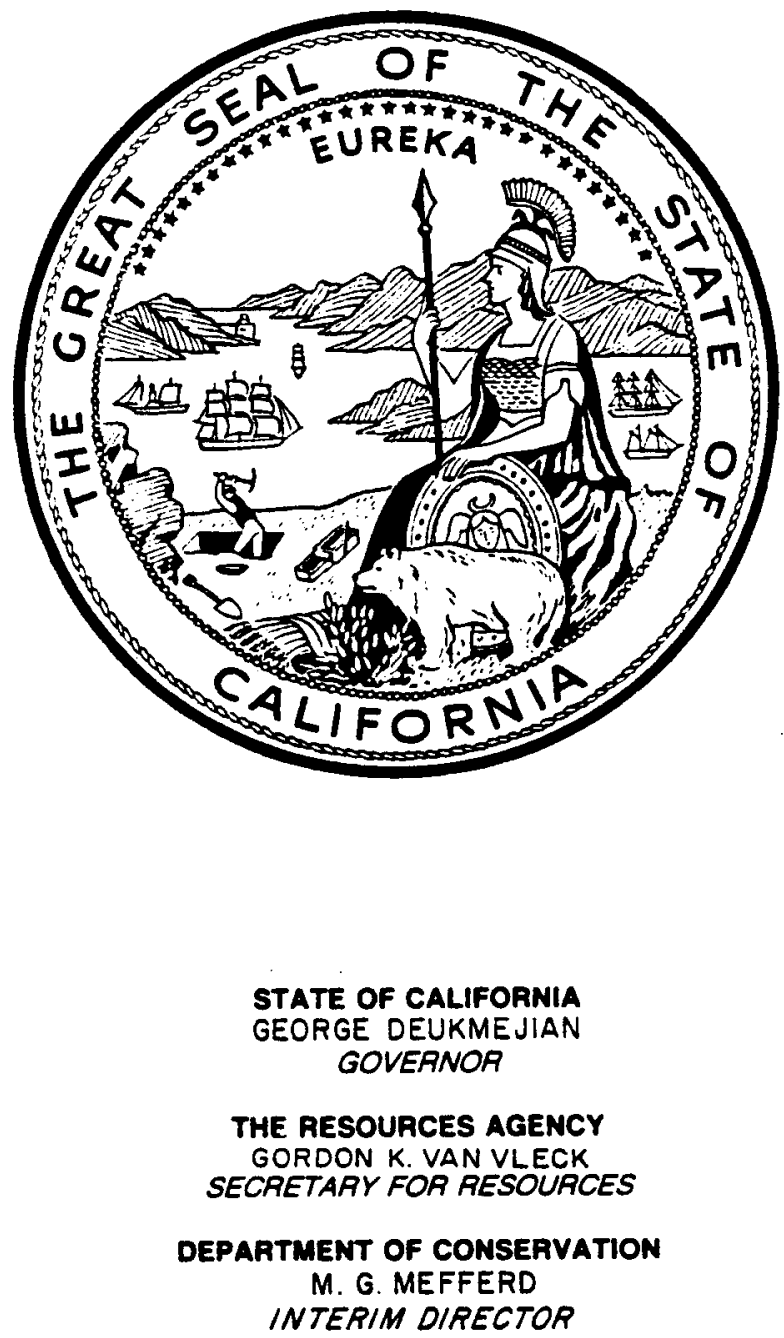

DIVISION OF MINES AND GEOLOGY JAMES F. DAVIS STATE GEOLOGIST 


\title{
INVESTIGATION OF LOW-TEMPERATURE
}

\author{
GEOTHERMAL RESOURCES IN THE
}

SONOMA VALLEY AREA, CALIFORNIA

Part of the Fourth Year Report, 1981-82, for the U.5. Department of Energy - California State-Coupled Program

$$
\text { for }
$$

Reservoir Assessment and Confirmation

by

Les! ie G. Youngs $\frac{1}{1}$

Rodger H. Chapman $\frac{2}{2}$

Gordon W. Chase $\underline{2} /$

Stephen P. Bezore 3 /

Hasu H. Ma jmundar 4

This work was performed under Grant No. DE-FG03-81SF10855 for the U.S. Department of Energy, Division of Geothermal Energy, by the California Department of Conservation. Division of Mines and Geology.

Geologist/Geophysicist, California Division of Mines and Geology

2/ Geophysicist, California Division of Mines and Geology

4/ Geochemist, California Division of Mines and Geology 


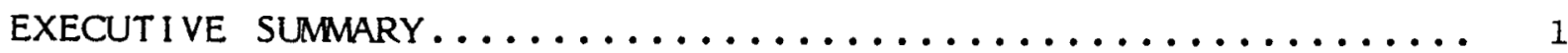

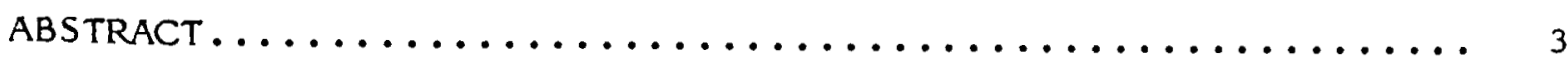

INTRODUCT ION. .............................. 5

HISTORICAL DEVELOPMENT OF THE GEOTHERMAL RESOURCES

IN THE SONOMA VAlley AREA, CALIFORNIA.............. 7

Background...........................

Development of the Hot Springs............... 7

Morton's Warm Springs (Los Guilicos

Warm Springs).......................... 7

The McEwan Ranch Warm Spring............... 8

The Sonoma State Hospital Warm Spring

(State Home at Elridge).................. 8

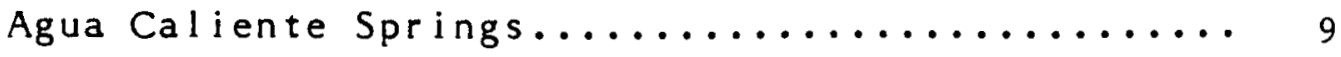

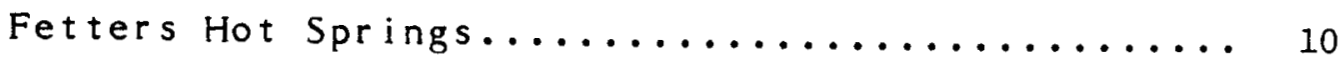

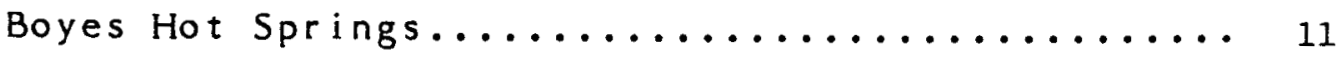

Other Possible Historic Geothermal Locales

in the Sonoma Valley Area.................... 14

Development of Geothermal Wells............... 15

Conclusions.............................. 16

GEOLOGIC SETTING.......................... 17

Introduction............................ 17

Stratigraphy.......................... 17

Petaluma Formation........................ 17

Sonoma volcanics........................ 17

Lower Undifferentiated Sonoma Volcanics...... 19

St. Helen Rhyolite...................... 19 
Page

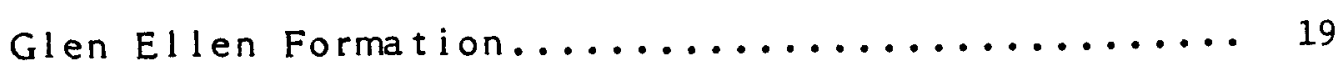

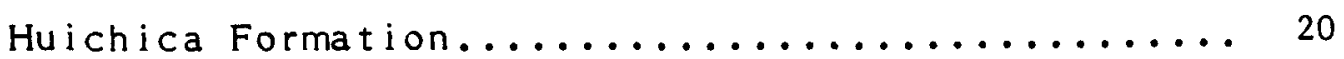

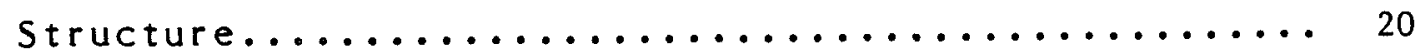

GROUND WATER HYDROLOGY ......................... 21

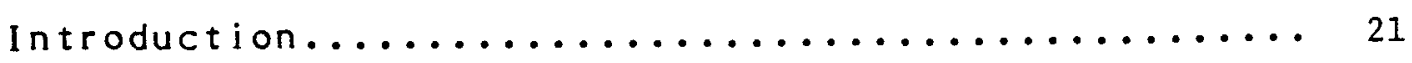

Hydrologic Properties..................... 21

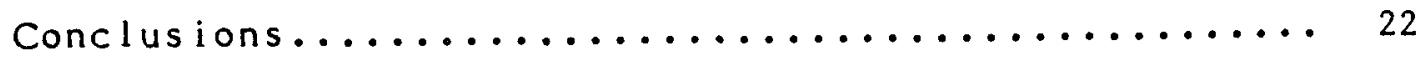

GEOPHYSICAL INVESTIGATIONS ..................... 23

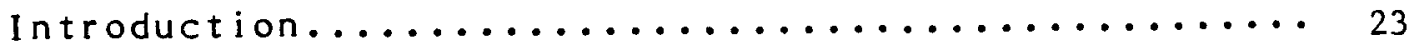

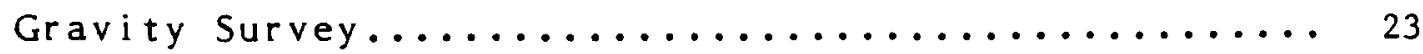

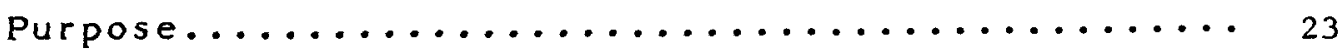

Equipment and Field Procedure............... 23

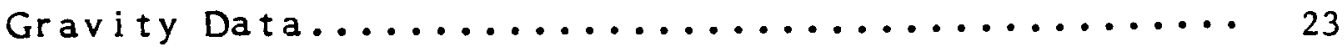

Interpretation of Gravity Data............. 42

Magnetic Surveys........................... 44

Purpose................................. 44

Aeromagnetic Data............................ 44

Equipment and Field Procedures for

Ground Survey........................... 44

Interpretation of Ground Magnetic Data........ 45

Seismic Refraction Surveys.................... 45

Purpose.............................. 45

Equipment and Field Procedure............... 49

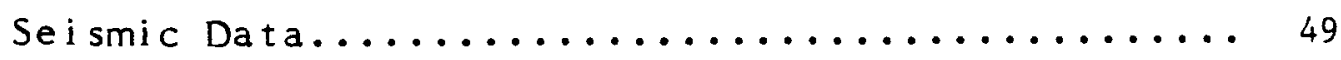

Electrical Resistivity Surveys.................. 51

Purpose............................... 51 
Equipment and Field Procedure............. 51

Interpretation of Resistivity Data........... 52

Dipole-Dipole Profiles.................. 52

Vertical Electrical Soundings (VES)........ 53

Conclusions and Recommendations............... 57

REGIONAL SEISMICITY OF THE SONOMA VALLEY AREA.......... 59

Introduction........................... 59

Methodology ........................... 59

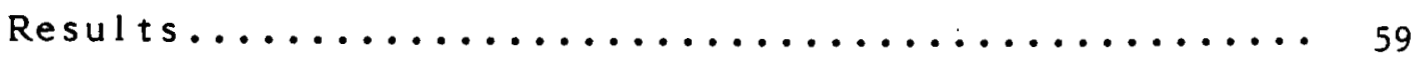

Conclusions........................... 63

GEOCHEMI STRY ............................... 65

Introduction.............................. 65

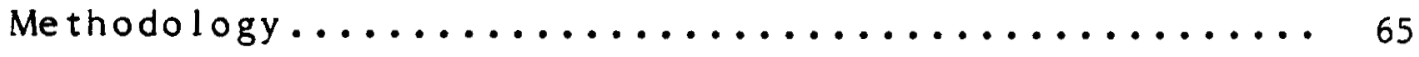

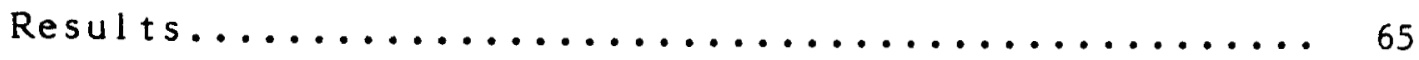

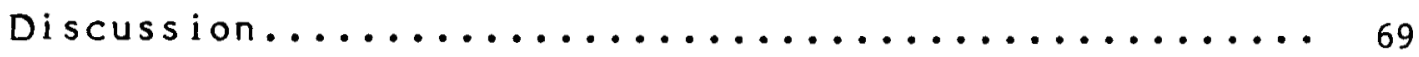

GEOTHERMOMETRY ........................... 71

Introduction........................... 71

Me thodology .......................... 71

Results................................ 73

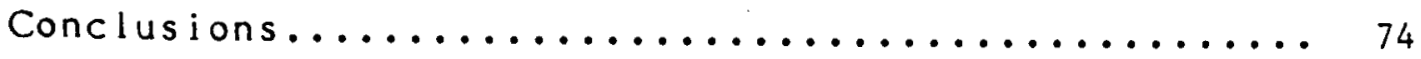

DIRECT TEMPERATURE MEASUREMENTS OF THE SONOMA VALLEY

GEOTHERMAL AREA......................... 75

Introduction........................... 75

Me thodology ........................... 75

Results.................................. 75

Conclusions............................. 83 
CONCLUSIONS AND ASSESSMENT OF THE GEOTHERMAL

RESOURCE ................................ 85

Introduction................................ 85

Areal Distribution.......................... 85

Depth of Resource........................ 86

Volume of Geothermal Resources................ 87

Temperature of Geothermal Resources............. 87

Reservoir Model........................ 88

Conclusions and Recommendations................ 90

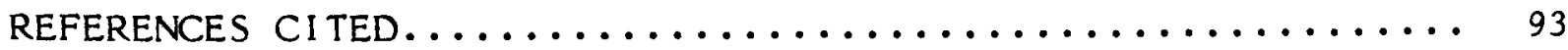

SELECTED REFERENCES FOR THE SONOMA VALLEY

LOW-TEMPERATURE GEOTHERMAL RESOURCE AREA,

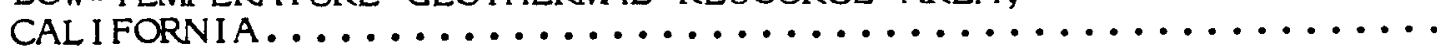

CALI FORNIA DIVISION OF MINES AND GEOLOGY

GEOTHERMAL PUBLICATIONS..................... 101 


\section{LIST OF TABLES}

Page

TABLE 1. Tabulated data of the earthquakes that have occurred within the Sonoma Valley

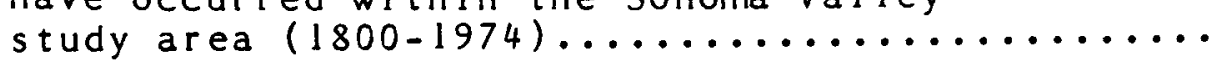

TABLE 2. Geochemical analyses of 41 wells and springs sampled in the Sonoma Valley area........ 66

TABLE 3. Mole ratios of major and minor constituents in well waters of the Sonoma Valley area,

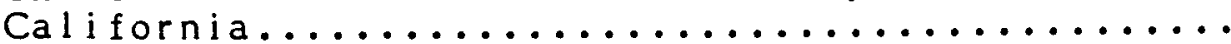

TABLE 4. Geothermometry temperature values $\left({ }^{\circ} \mathrm{C}\right)$

for selected water wells and springs in

the Sonoma Valley area, Sonoma County,

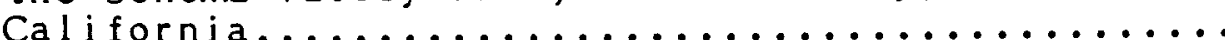

TABLE 5. Direct temperature measurements of selected geothermal wells and springs (temperature $>20^{\circ} \mathrm{C}$ ) in the Sonoma Valley area, Sonoma and Napa Counties,

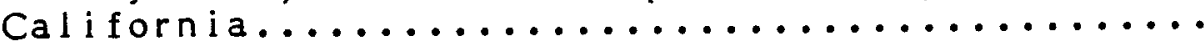




\section{LIST OF FIGURES}

Pag $\underline{\text { e }}$

FIGURE 1. Location map of the Sonoma Valley

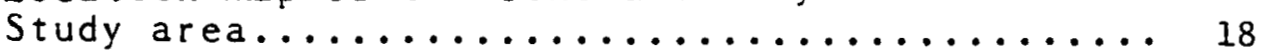

FIGURE 2. Gravity profile F-F', Sonoma area........... 24

FIGURE 3. Line G-G', showing gravity and

magnetic profiles, Sonoma area............ 25

FIGURE 4. Gravity profiles $H_{-} H^{\prime}$ and $K-K^{\prime}$, and magnetic profile $K_{-K^{\prime}}$, Sonoma area........ 26

FIGURE 5. Residual gravity profile $\mathrm{H}_{-} \mathrm{H}^{\prime}$ and interpretation, Sonoma area.............. 27

FIGURE 6. Line $I^{-I} I^{\prime}$, showing gravity and magnetic profiles and resistivity pseudo section, Sonoma area.............. 28

FIGURE 7. Gravity profile, J-J', Sonoma area.......... 29

FIGURE 8. Gravity profile L-L', Sonoma area.......... 30

FIGURE 9. Gravity profile M-M', Sonoma area.......... 31

FIGURE 10. Gravity profile $N-N^{\prime}$, Sonoma area........... 32

FIGURE 11. Gravity profile O-O', Sonoma area........... 33

FIGURE 12. Gravity profile P-P', Sonoma area.......... 34

FIGURE 13. Gravity profile Q-Q', Sonoma area.......... 35

FIGURE 14. Line S-S', showing gravity and magnetic profiles and dipole-dipole resistivity pseudo section, Sonoma

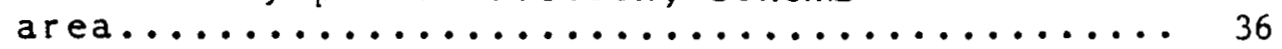

FIGURE 15. Line T-T', showing gravity and magnetic profiles, Sonoma area............ 37

FIGURE 16. Line U-U', showing gravity and magnetic profiles, Sonoma area............ 38

FIGURE 17. Line V-V', showing gravity profile and seismic refraction section,

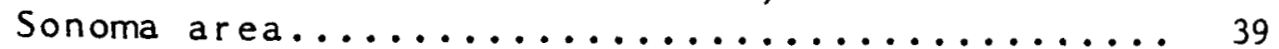

FIGURE 18. Line W-W', showing gravity and magnetic profiles, Sonoma area............ 40 
FIGURE 19. Line $Y-Y^{\prime}$, showing gravity and

magnetic profiles, Sonoma area........... 41

FIGURE 20. Magnetic profile MA-MA', Sonoma

area........................... 46

FIGURE 21. Magnetic profile MB-MB', Sonoma

area.......................... 47

FIGURE 22. Magnetic profile MC-MC', Sonoma

area........................... 48

FIGURE 23. Line I-I', showing seismic

refraction section, Sonoma area.......... 50

FIGURE 24. Schlumberger sounding 1 and

interpretation, Sonoma area............. 54

FIGURE 25. Schlumberger sounding 2 and

interpretation, Sonoma area............. 55

FIGURE 26. Schlumberger sounding 3 and

interpretation, Sonoma area............ 56

FIGURE 27. Temperature log - Morton's Hot

Spring warm well.................... 78

FIGURE 28. Temperature log - Sonoma State

Hospital warm well.................. 79

FIGURE 29. Temperature log - Agua Caliente

Villa warm well.................... 80

FIGURE 30. Temperature log - Boyes Hot Spring we 11 no. 2 (?).......................... 81

FIGURE 31. Temperature log - Salt Ranch warm we $11 \ldots \ldots \ldots \ldots \ldots \ldots \ldots \ldots \ldots \ldots \ldots \ldots . \ldots \ldots$

FIGURE 32. Diagramatic cross section of

the low-temperature geothermal reservoir in the Sonoma Valley

area, California........................ 89

FIGURE 33. Temperature ranges of some possible geothermal direct uses................. 91 


\section{LIST OF PLATES}

PLATE 1. Location of selected geothermal wells and springs, Sonoma Valley area, Sonoma and Napa Counties, California.

PLATE 2. Geology of the Sonoma Valley area, Sonoma County, California.

PLATE 3. Bouguer gravity map, Sonoma Valley area, Sonoma County, California.

PLATE 4. Residual gravity map, Sonoma Valley area, Sonoma County, California.

PLATE 5. Aeromagnetic map, Sonoma Valley area, Sonoma and Napa Counties, California.

PLATE 6. Seismicity of the Sonoma Valley area, Sonoma and Napa Counties California (1800-1974).

PLATE 7. Geochemistry sample locations, Sonoma Valley area, Sonoma County area, California.

PLATE 8. Na-K-Ca $(B=4 / 3)$ geothermometry map, Sonoma Valley area, Sonoma County, California.

PLATE 9. Na-K-Ca $(B=1 / 3)(\mathrm{Mg}$ corrected) geothermometry map, Sonoma Valley area, Sonoma County, California. 


\section{EXECUTIVE SUMMARY}

This report presents the results of the California Division of Mines and Geology's (CDMG) geothermal resource investigation of the Sonoma Valley area, California. The study was undertaken to learn more about the known low-temperature $\left(20^{\circ}-90^{\circ} \mathrm{C}\right)$ geothermal resource in this area and to assess the potential of the resource for development and use by the local community. The project was conducted in compliance with the terms of the fourth-year contract (1981-82) with the U.S. Department of Energy (DOE) under the state-coupled program and performed under CDMG's Phase II site-specific geothermal resources studies program.

This study has delineated a widely distributed, moderately shallow, low-temperature geothermal resource in the Sonoma Valley area. Utilization of this resource appears to be potentially feasible for a variety of direct-heat uses, and development of the resource is recommended. Some specific characteristics of the geothermal resource are presented below:

- The geothermal fluids underlying portions of the Sonoma Valley are primarily found in permeable units of the Sonoma Volcanics. The area labeled the "Most Likely Geothermal Production Zone" (Plate 1) is the most favorable area for developing these resources from moderately deep wells (over 100 meters/330 feet deep).

- The "Most Likely Geothermal Production Zone" contains 15 of the 29 low-temperature geothermal wells or springs found during the course of this investigation. The zone is bounded on the west by the "east side" fault and is approximately $10 \mathrm{~km}$ (6.2 miles) long and comprises an area of 5.4 square kilometers (2.1 miles 2 ).

- The highest recorded temperature of geothermal fluids found in the Sonoma Valley area is $62.7^{\circ} \mathrm{C}\left(145^{\circ} \mathrm{F}\right)$ at 137.2 meters $(450 \mathrm{feet})$ in a well at Boyes Hot Springs. The indicated temperature of the geothermal reservoir may be in the range of $52^{\circ}-77^{\circ} \mathrm{C}$ $\left(126^{\circ}-171^{\circ} \mathrm{F}\right)$ based on the average values of several algorithms of $\mathrm{Na}-\mathrm{K}-\mathrm{Ca}$ geothermometer. These data are questionable, however.

- All evidence suggests the low-temperature geothermal resources in the Sonoma Valley are characteristic of liquid-dominated hydrothermal convection systems. Deep circulating fluids are warmed from the earth's natural heat gradient and then ascend fracture zones into permeable aquifers underlying the Sonoma Valley.

- Of several possible faults that have been identified in the Sonoma Valley by geophysical investigations, the fault that has been designated the "east side" fault in this report is the most important with respect to geothermal resources. In the reservoir model the "east side" fault acts as a conduit for upward migration of geothermal fluids and simultaneously as a barrier to westward migration of the fluids. Therefore, warm waters enter permeable aquifers to the east of the "east side" fault.

Recommended further work includes the following:

- Assessment of actual production capability of the reservoir by drilling, developing, and monitoring wells for hydrologic parameters of discharge, temperature, drawdown, specific yield, etc. A deep explotation well drilling program would be of great value in assessing the reservoir characteristics and is strongly recommended. 
- A shallow-hole temperature probe survey may greatly refine our understanding of the distribution of heated fluids in the "Most Likely Geothermal Production Zone" on the east side of the Sonoma Valley, and is recommended for any additional study.

- Future geothermal studies of the Sonoma Valley should include geophysical surveys, geochemical sampling, downhole temperature measurements, and geologic mapping to delineate structures north and northwest of the study area to determine their relationship to the geothermal resources of the valley. The geoscientific surveys performed during this investigation were predominantly done in the central and southern portions of the Sonoma Valley. Preliminary information indicates several patterns, trends, and anomalies extending north and northwest of the study area. 


\begin{abstract}
Investigation of the Low-Temperature Geothermal

Resources in the Sonoma Valley Area, California
\end{abstract}

The Sonoma Valley area contains low-temperature geothermal resources $\left(20^{\circ} \mathrm{C} \leq \mathrm{T}<\right.$ $90^{\circ} \mathrm{C}$ ) having the potential for useful development. Sonoma Valley residents, local governments and institutions, private developers, and manufacturers may be able to utilize the geothermal resources as an alternate energy source.

Historically, there have been at least six geothermal spring areas developed in the Sonoma Valley. Four of these (Boyes Hot Springs, Fetter's Hot Springs, Agua Caliente Springs, and the Sonoma State Hospital warm spring) lie on a linear trend extending northwestward from the City of Sonoma. Detailed geophysical surveys delineated a major fault trace along the east side of the Sonoma Valley in association with the historic geothermal areas. Other fault traces were also delineated revealing a general northwest-trending structural faulting fabric underlying the valley.

Water wells located near the "east side" fault have realtively high boron concentrations. Geochemical evidence may suggest the "east side" fault presents a barrier to lateral fluid migration but is a conduit for ascending fluids. Fifteen of the twenty-nine geothermal wells or springs located from literature research or field surveys are located along or east of this major fault in a $10 \mathrm{~km}(6.2$ miles) long, narrow zone.

The highest recorded water temperature in the valley appears to be $62.7^{\circ} \mathrm{C}\left(145^{\circ} \mathrm{F}\right)$ at 137.2 meters (450 feet) in a well at Boyes Hot Springs. This is consistent with the geothermal reservoir temperature range of $52^{\circ}-77^{\circ} \mathrm{C}\left(126^{\circ}-171^{\circ} \mathrm{F}\right)$ indicated by geothermometry calculations performed on data from wells in the area.

Interpretation of data indicates a low-temperature geothermal fluid up-welling or "plume", along the "east side" fault with subsequent migration into permeable aquifers predominantly within volcanic strata. It is quite likely other geothermal fluid "plumes" in association with faulting are present within the Sonoma Valley area. A $5.8 \mathrm{~km}^{2}$ geothermal zone, that parallels the fault trace, is delineated and is perhaps the most favorable area for further investigation and possible geothermal production. 
b

8

.

7

8

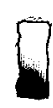

8

.

D

$\nabla$

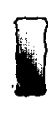

.

.

8

8

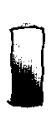




\section{INTRODUCTION}

The California Division of Mines and Geology (CDMG), under grant contract with the U.S. Department of Energy, investigated the low-temperature $\left(20^{\circ}-90^{\circ} \mathrm{C}\right)$ geothermal resources of the Sonoma Valley area, California, to determine the areal extent, depth, maximum temperature, volume, water quality and other properties of these resources that must be ascertained before effective and economical development is undertaken. This report presents a summary of historical development of the resources and the results of geological investigations, detailed geophysical surveys, a study of the regional seismicity, geothermometric calculations, geochemical analyses of water samples, and direct temperature measuring, as well as conclusions drawn from these results. At the end of the report is a list of selected references of geoscience information concerning the Sonoma Valley area.

In recent years, there has been an awakening interest in alternate energy sources. As a result, the potential of low- to moderate-temperature geothermal resources is coming under scrutiny throughout California. This report presents the basic geoscientific aspects of the geothermal resources of the Sonoma Valley area and should be used as a "springboard" for all those with an interest in those resources. Data provided in this report should be helpful for local residents, local governments, private developers, and manufacturers in the Sonoma Valley to ascertain if they are located in a favorable area for geothermal development. This report may then be used as a bases for a more detailed or localized exploration. program. The report can be used in support of financial requests to state and federal government geothermal development aid programs. The data and conclusions presented in this report may affect the kinds of uses to which the geothermal resources of Sonoma Valley may be applied, the type of equipment necessary to utilize the resources, and the total cost-effectiveness of potential utilization of the resources.

This report presents much new material as well as a compilation of previously performed studies singularly assembled for the purpose of investigating the geothermal resources of the Sonoma Valley area. Although this report is a comprehensive geothermal study of the area, it is not meant to be the definitive or final study of the geothermal resources of Sonoma Valley. Concepts and conclusions presented in this report should be continuously revised, modified, upgraded, and may, in some cases, be rejected as new data from subsequent studies are developed for the geothermal resources of the Sonoma Valley area.

This report is a product of the cumulative effort of several CDMG staff scientists. Rodger H. Chapman and Gordon W. Chase performed the detailed geophysical field investigations, processed and interpreted the data, and prepared the geophysical presentation in this report. Stephen $\mathrm{P}$. Bezore performed the geologic field investigations and prepared the geologic presentation. He also researched and prepared the selected reference list at the end of the report. Hasu $H$. Majmundar was responsible for the geochemical water well sampling program conducted in the Sonoma Valley. He collected samples, directed the sample analyses that were performed at CDMG's San Francisco laboratory, and tablulated the results. Leslie G. Youngs was the principal field investigator for the project and wrote the remaining sections of the report. He was responsible for report continuity and overall geothermal resource assessment interpretations. 
$\square$

8

.

.

.

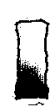

$B$

D

8

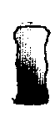

.

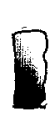

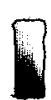

8

.

.

8

.

D 


\section{HISTORICAL DEVELOPMENT OF THE GEOTHERMAL RESOURCES IN THE SONOMA VALLEY AREA, CALIFORNIA}

\section{Background}

One of the data gathering techniques used in the investigation of a geothermal resource area should be the researching and compiling of the historic development of that resource. Information such as the number and locations of warm wells and springs, flow rates, temperatures, geothermal surface features, depth of geothermal aquifers, historical depletion of the resource, surface extent of the resource, and past uses made of the resource can often be gleaned from the historical record (California Division of Oil and Gas, 1981). This often has proven to be an especially valuable technique in low- and moderate-temperature geothermal resource areas of California where many warm or hot springs were originally developed as resort spas or health sanitariums. Much literature has survived from that era advertising and extolling the chemical and physical properties of various hot springs. The historic record of "hot springs" in the Sonoma Valley area is somewhat sparse, but there is some very useful information available.

\section{Development of the Hot Springs}

There are six historic geothermal springs areas most of ten mentioned in literature in the Sonoma Valley area. They are from north to south: Morton's warm springs (formerly Los Guilicos Warm Springs), the McEwan Ranch warm spring, the Sonoma State Hospital warm spring (formerly State Home at Eldridge), Agua Caliente Springs, Fetter's Hot Springs, and Boyes Hot Springs (Plate 1).

\section{Morton's Warm Springs (Los Guilicos Warm Springs)}

The Morton's Warm Springs recreational site is located approximately $2.4 \mathrm{~km}(1.5$ miles) south of the City of Kenwood on the east bank of Sonoma Creek and adjacent to Warm Springs Road. (Plate 1, Location No. C-4).

It is interesting to note that "... in the early 1800 's, the land (the northern Sonoma Valley) was swampy and covered with heavy growths of Willows, alders, bay and oak; the site of Kenwood being entirely under water." (Cook, 197?, p. 46). In 1887, the land was drained, and the town, later to be named Kenwood, was laid out. The next year, a plot of land was set aside at the natural warm springs, previously a favorite camping ground of the Wappo Indians of the northern Sonoma Valley. The marshy, tidewater lands of the southern Sonoma Valley were originally occupied by the Coast Miwok Indians (Beard, 1979).

Waring (1915) writes of two springs at Los Guilicos Warm Springs site which yielded about 2 and $3 \mathrm{gpm}$, respectively, at water temperatures of $25.6^{\circ} \mathrm{C}\left(78^{\circ} \mathrm{F}\right)$ and $27.8^{\circ} \mathrm{C}\left(82^{\circ} \mathrm{F}\right)$ :

"In 1909 there was a small bathing pool and an old hall or pavilion at the spring near the eastern bank of the creek; at the other spring, on the opposite bank, there was a small pool enclosed by an old bathhouse. The place was used as a camping resort, and several cottages had been erected among the trees near by."

Berkstresser (1968) lists three geothermal features at the Morton's Warm Springs site; the first two listed, probably are wells, the third is listed as a shelter-covered spring. The temperatures, respectively, are $30.6^{\circ} \mathrm{C}\left(87^{\circ} \mathrm{F}\right)$ measured on November $1,1956,28.9^{\circ} \mathrm{C}$ $\left(84^{\circ} \mathrm{F}\right)$ measured on November 1,1956 , and $30.6^{\circ} \mathrm{C}\left(87^{\circ} \mathrm{F}\right)$ measured on October $1,1966$. 
Currently at the site, a well about 55 meters (180 feet) deep and $31.8 \mathrm{~cm}$ (12.5 inches) in diameter supplies warm water for filling two swimming pools, irrigating the picnic grounds, space-heating the structure on the premises, and supplying the domestic water supply to 20 nearby residences under the auspices of the Los Guilicos Water Works. The well, despite this heavy load, flows artesian during the winter months. The surface discharge water temperature measured on February 24,1982 was $30^{\circ} \mathrm{C}\left(89^{\circ} \mathrm{F}\right)$. Natural warm water seepage is still sometimes evident in the bottom of the Sonoma Creek behind the swimming and picnicing facilities.

The McEwan Ranch Warm Spring

According to Waring (1915), the McEwan Ranch Warm Spring was located about 2.4 $\mathrm{km}$ (1.5 miles) west of Los Guilicos Warm Springs. Waring claims the spring was partly used for irrigation, but that the spring had not been efficiently developed or improved.

It is assumed that an undeveloped warm spring on the property currently known as the Kiezer Ranch on Bennett Valley Road is the same spring in Waring's 1915 account. (Plate 1, Location No. C-5.) The spring surfaces very near the ranch house at a temperature of $23.3^{\circ} \mathrm{C}\left(74^{\circ} \mathrm{F}\right)$ and flows through a narrow ditch to the Yulupa Creek. The temperature reportedly remains constant year round. The spring was discharging at approximately $25 \mathrm{gpm}$ on February 23, 1982. It appears that this spring was never commercially developed. A well of unknown depth has been driven about one meter or so away from the spring. This well supplies the entire water requirements of the residents at the ranch.

The Sonoma State Hospital Warm Spring (State Home at Eldridge)

The Sonoma State Hospital grounds are along Arnold Drive and Sonoma Creek approximately $8 \mathrm{~km}$ ( 5 miles) north-northwest of the City of Sonoma. The location of the warm spring on these grounds, as described in the literature, is confusing, but interpretation suggests it is the site labeled as "Sonoma State Hospital Warm Well" on Plate 1 which is on the hospital's farm.

Waring (1915) writes:

"At the vegetable and dairy farm of the State Home at Eldridge water $\left(22^{\circ} \mathrm{C}\right) 72^{\circ}(\mathrm{F})$ in temperature is obtained from a spring that yields about 10 gallons a minute of water that is used in the dairy and for irrigation. The water broke forth at this spring at the time of the earthquake of April 18, 1906, and a flowing well 50 yards northward ceased to flow. A light colored tuffaceous rock is exposed a few yards from the spring."

Berkstresser (1968) writes of an October 10, 1966 observation of the spring:

"Spring is developed on bank of creek and covered by concrete shelter. Water drains through pipe into creek. Unused."

He measured the water temperature at $21^{\circ} \mathrm{C}\left(70^{\circ} \mathrm{F}\right)$ and reported a $10 \mathrm{gpm}$ discharge.

During the CDMG field work of February 22, 1982, a 3-meter (10 feet) diameter, 7 meters ( 23 feet) deep concrete cistern was investigated on the farm of the Sonoma State Hospital. This is the site labeled "Sonoma State Hospital Warm Well" on Plate 1. The cistern is covered with a hemispherical concrete lid. The temperature of the water at the bottom of the cistern was $20.3^{\circ} \mathrm{C}\left(68.5^{\circ} \mathrm{F}\right)$. The well or cistern is unused and was not discharging. It is assumed that this cistern is the site of the warm spring mentioned in 
the literature above. The site labeled "S-22" on Plate 1 is probably located incorrectly and is, in fact, the cistern described above.

Currently, there is no use made of the low-temperature geothermal resource possibly available at the Sonoma State Hospital, but a proposal by a private contractor has been approved by the California State Lands Commission to drill a deep exploration well on the grounds to develop geothermal resources. Drilling began in July 1982.

\section{Agua Caliente Springs}

The Agua Caliente Springs resort is a day-use swimming and picnicking facility 4.3 $\mathrm{km}$ (2.7 miles) northwest of the center of the City of Sonoma along and west of Highway 12. (Plate 1, Location No. C-40.)

Agua Caliente Springs has operated commercially since 1887 (Leivas and others, 1981). Finley (1937) says the springs were originally developed in the early " 80 's". Before that ". . . the hot spring here was merely a mud hole used for many years by the Indians" (Bradley, 1915).

A well that flows artesian was dug at the nearby Agua Rica Hot Springs (now Boyes Hot Springs) in 1895. This phenomena drew much publicity so the owner of Agua Caliente Springs Hotel decided to try to dig an artesian well on his property with the following results as reported by Lynch (date unknown):
"Dr. Nordin, then the new owner of the Agua Claiente Springs Hotel and grounds, employed workers to dig an artesian well with the same hopes in mind. In May, 1895, an excellent flow of hot mineral water was found. The stream shot up to several feet above the surface of the ground and carried an average tempeature of 100 degrees $\left(37.8^{\circ} \mathrm{C}\right)$. Dr. Nordin and his crew immediately began making plans to build swimming baths and like facilities. Improvements were also made on the nearby buildings and interiors were refurbished."

Apparently the resort thrived as many people rode the Northwestern Pacific Railroad up the Sonoma Valley from the Bay Area to "take the waters". Agua Caliente was a small train station on that rail line. There was a convenient horse and buggy service from the depot to the local resorts.

In 1915. Waring wrote this account of Agua Caliente Springs:

"A hotel and cottages here provide for about 300 people. A large swimming plunge and tub baths are supplied by five flowing wells one-third of a mile southward. The wells are drilled about 300 feet $(9 \mathrm{Im})$ deep and the reported temperatures of the waters range from $97^{\circ}\left(36^{\circ} \mathrm{C}\right)$ to $108^{\circ}\left(42^{\circ} \mathrm{C}\right)$. In 1909 Agua Caliente water was bottled and marketed both carbonated and natural for table use."

The following account, a few years later (Bradley, 1915), indicates an additional well at the site, to a total of six, and perhaps a reduction in artesian flow to seasonal:

"The present owner has drilled six wells and put in a large swimming tank, a bathhouse, and a bottling works. The water is pumped, though it is stated that in the winter the wells have a small artesian flow. 
"The water pumped to the swimming tank shows a temperature of $102^{\circ} \mathrm{F}\left(39^{\circ} \mathrm{C}\right)$ at the pump ( 2 wells combined, 1 of which is said to be warmer than $\left.102^{\circ} \mathrm{F}\left[39^{\circ} \mathrm{C}\right]\right)$. The well from which water is bottled shows a temperature of $95^{\circ} \mathrm{F}\left(35^{\circ} \mathrm{C}\right)$ at the pump, and is discharged into a tank to cool before bottling. Electric power is used, and there is an auxiliary gasoline mechanical labeler. There are accommodations for 300 guests in the hotel and cottages."

Leivas and others, 1981, report that in 1950, the resort was purchased by the present owner. The grounds were cleaned, trees planted, and the mud baths removed. Currently, the owners operate a day-use area with swimming pool, which is filled from three wells, two on the Agua Claiente property. Warm water from the adjacent Fetter's Hot Springs property, now owned by the same people who own Agua Caliente Springs, is also used in filling the pool.

In 1981, a temperature of $35^{\circ} \mathrm{C}\left(95^{\circ} \mathrm{F}\right)$ was recorded in the discharge of a well approximately $91.4 \mathrm{~m}$ (300 feet) deep at Agua Caliente Springs.

\section{Fetters Hot Springs}

The Fetters Hot Springs site is adjacent to and south of the above Agua Caliente Springs resort along Highway 12 northwest of the City of Sonoma. (Plate 1, Location No. C-41.)

Originally, the site was known as Eleda Hot Springs when commercial development began in 1908 with the drilling of a warm water well.

"During the summer of 1909 a bathing establishment (Eleda Hot Springs) which is supplied by four drilled wells was erected about 200 yards east of the Agua Caliente baths", reported Waring (1915).

In 1910, a hotel was built on the grounds. By 1915, the resort was called Fetters Hot Springs.

Bradley (1915) writes of the resort:

"This resort at the post office of the same name (Fetters Hot Springs) is between Boyes and Agua Caliente springs in the warm water belt, extending northwesterly from Sonoma... There are 3 wells, stated to be artesian in winter, the first one of which was drilled in 1908. The warm water was struck at a depth of 300 feet $(91.4 \mathrm{~m})$. It is pumped, using electric power, to a tank, for swimming and bathing. A small amount is bottled, carbonated, for use at the hotel. The temperatures of the two principal wells are said to be $114^{\circ} \mathrm{F}\left(46^{\circ} \mathrm{C}\right)$ and $90^{\circ} \mathrm{F}\left(32^{\circ} \mathrm{C}\right)$ respectively."

Currently, the Fetters Hot Springs site is closed. The facilities are gone except for one building apparently used as a small, single-story, low-rent apartment complex and a warm water well. The property is now owned by the owners of the adjacent Agua Caliente Springs resort.

The well is sometimes used to help fill the pool at the Agua Caliente Springs facilities. Leivas and others (1981) report the well to be $50.3 \mathrm{~m}$ (165 feet) deep with a surface discharge temperature of $29^{\circ} \mathrm{C}\left(84^{\circ} \mathrm{F}\right)$. Compare this to the nearby Agua Caliente Springs well measured by Leivas and others (1981) at approximately $91.4 \mathrm{~m}$ (300 feet) and discharging at $35^{\circ} \mathrm{C}\left(95^{\circ} \mathrm{F}\right)$. The comparison may indicate an increase in geothermal fluid temperature with an increase in depth in this immediate area. 
The Boyes Hot Springs site is approximately $3.2 \mathrm{~km}(2$ miles) northwest of the City of Sonoma on the east bank of Sonoma Creek. (Labeled "Boyes Hot Springs" on Plate 1.)

The Boyes Hot Springs were the oldest developed geothermal springs in the Sonoma Valley, probably first commercialized on a small scale in the late 1840's or early 1850 's, by Dr. T.M. Leavenworth. But before that there are several reports that local Indians utilized the site.

Gregory (1911):

"In the Sonoma region are the Boyes Hot Springs on the old Leavenworth rancho in the northern part of the valley. This well known and very popular health resort could date the beginning of its popularity before dates were used in the markings of time-flights. The Indians found the spring boiling and bubbling in its own hot vapors from the ground... So their sweathouse stood near the spring. . . for generations. .. Dr. Leavenworth constructed a small bathhouse and a tank at the spring (circa 1850?) and made it the pioneer health resort of the county. The doctor was peculiar and eccentric to the explosive point--which point one day he reached during a violet discussion with his wife over the cashierhsip of the institution. In his rage he burned the bathhouse and filled the tank with earth and stones and went out of business."

In those early days, the site was known as the Agua Rica Springs. Captain and Mrs. H.E. Boyes acquired the property in the late 1880's as the following account by Gregory (1911) relates:

\footnotetext{
"Making this their home (Sonoma Valley), they soon became interested in stories told them by the late General Vallejo of the old hot mineral springs used by the Indians and upon inestigation. . .Mr. Boyes after long probing in the swampy soil found the old tank in its excavation. .. the captain digging into the earth and Mrs. Boyes hoisting the bucket. . . cleaned out the long choked fountain (and) set (it) boiling again... Accordingly they purchased seventy-five acres of land and began developing the springs. Sinking two deep wells each two hundred feet in depth [this was in 1888] they put in one tub to start with and then increased and built and rebuilt until now it is the finest hot mineral spring resort in California."
}

The following is a chronological listing of historical statements about the geothermal resource and facilities at Boyes Hot Springs (originally Agua Rica Springs):

Watts (1892):

"Inflammable gas (methane?) bubbles up from the bed of Sonoma Creek on the Captain Boyes ranch, about 2 miles north of Sonoma. About 100 feet from the creek is a thermal spring... The temperature of this spring has been estimated at $100^{\circ} \mathrm{F}\left(38^{\circ} \mathrm{C}\right)$ and the water is kept in a state of ebullition by the inflammable gas (methane?) which arises from it. Captain Boyes states that he has 
estimated the amount of gas yielded by the spring at 9,000 feet in twenty-four hours. ...

"A few yards to the east of the spring, and 120 feet from the creek, a boring was made by Captain Boyes to a depth of 37 feet.

"At this depth the well yielded inflamable gas and water of about the same temperature as the spring already mentioned. The flow of water from this spring has been estimated at a quarter of a million gallons in twenty-four hours. A 6-inch hose siphoned water into the creek continuously for twenty-four hours without lowering the water in the spring."

Crawford (1894):

"Agua Rica Springs - They are near Verano, on the Donahue Railroad. There are five principal spririgs."

Lynch (date unknown):

"Workers drilling on the property of Captain and Mrs. H.E. Boyes, March 18, 1895, made a discovery that would soon lead to the development of one of Sonoma Valley's biggest attractions - natural hot springs.

"On that landmark day of 1895, workers struck the flowing well of hot water after drilling a depth of 70 feet. Temperature of the water was $112^{\circ} \mathrm{F}\left(44^{\circ} \mathrm{C}\right)$, almost hot enough to boil an egg. Accompanying the water was an immense volume of natural gas which, it was said, was enough to supply the entire City of Sonoma with light.

"For two years, Captain Boyes had been conducting a search for the hot mineral, artesian water and natural gas. After the initial discovery in March, 1895, an additional underground stream of hot mineral water was struck which, according to Index-Tribune account, 'burst up to the surface through a 7 inch pipe to a height of several feet above the ground, amid a vapor of steam that caused the eyes of astonished well laborers to bulge out like doorknobs'. The flow estimated at 100,000 gallons per day, the temperature $112^{\circ} \mathrm{F}\left(44^{\circ} \mathrm{C}\right)$.

"Professors and other geological and mining authorities flocked to Sonoma Valley to study the new found springs. The Agua Rica Hot Springs, formed to promote the hot springs' recreational and medicinal values, was soon incorporated."

Crawford (1896):

"Agua Rica Hot Sulphur. They are 2 miles N. of Sonoma, and on the line of S.F. \& N.P.R.R. They are sixteen in number, varying in temperature from the cool iron and soda water to the hot saline-sulphurous springs, registering $111.5^{\circ} \mathrm{F}\left(44^{\circ} \mathrm{C}\right)$. On the property also there are mud [bath] springs, whose merits are highly extolled. 
Apparently the name change to Boyes Hot Springs became official in 1902 when the Boyes' Hot Mineral Springs Company was formed by Captain Boyes. He retired from the management in 1904. So that by the publication of the following account by Waring (1915), there were new owners at the springs:

"Here a hotel and several cottages and tent houses are situated in a grove of oaks, and a quarter of a mile northwest of the hotel a large swimming plunge and tub baths are supplied by water pumped from two wells. These are said to be 200 feet deep, and the temperature of the water is reported to De $114^{\circ} \mathrm{F}\left(46^{\circ} \mathrm{C}\right)$ and $118^{\circ} \mathrm{F}\left(48^{\circ} \mathrm{C}\right)$. The wells, the first of which was drilled about 1890 , flowed until a short time after the earthquake of April 18, 1906, but the water usually stands a few feet below the surface. A third, unused well 300 to 400 yards to the east was flowing about 3 gallons a minute in December, 1909. The water is bottled for table use...."

Bradley (1915):

"Boyes Hot Springs (at one time called Agua Rica), Boyes Hot Springs Company, owners; Henry Trevor, San Francisco, president; Thos. P. Boyd, Santa Rosa, secretary; R.G. Lichtenberg and Dr. E.L. Parramore, managers. The post office and railroad station are both named Boyes Springs... The property was formerly owned by Captain Boyes, and has been operated by the present company for seven years.

"Water is obtained from both springs and wells. It is pumped to tanks to give pressure for the bathhouse use, and also pumped to the bottling works, where it is cooled before bottling. Electric power is used. The bottling is done under lease from the company by John W. Kelly. Most of the production is carbonated, but a few cases per month, 'still.'

"There is a fine large swimming pool and a well-appointed bathhouse. The temperature of the water of the principal spring was $112^{\circ} \mathrm{F}\left(44^{\circ} \mathrm{C}\right)$, taken at the pump. There are accommodations for 300 guests in the hotel, cottages and tents."

Laizure (1926):

"Boyes Hot Springs. Owned by Sonoma Properties Company. Fred F. Partridge and R.G. Lichtenberg, managers.

"Water is obtained from both springs and wells. It is pumped to tanks to give pressure for the bathhouse use, and also pumped to the bottling works, where it is cooled before bottling. Electric power is used. The bottling is done under lease from the company. All of the production is carbonated. There is a fine large swimming pool with water at $80^{\circ} \mathrm{F}\left(27^{\circ} \mathrm{C}\right)$ and a hot plunge, both in a well-appointed bathhouse. The old hotel burned down in 1923. The Sonoma Properties Company, which has recently taken over the Boyes Springs property, expect to have a new 100-room hotel completed in 1927. A cafe seating 300 , open to the public, and an 18-hole golf course are included in their plans." 
Berkstresser (1968):

Reported from an October 1, 1966 observation that the water temperature at Boyes Hot Springs was $112^{\circ} \mathrm{F}\left(44^{\circ} \mathrm{C}\right)$.

Sylvester Associates (1982):

Reported a bottom hole temperature of $145^{\circ} \mathrm{F}\left(62.8^{\circ} \mathrm{C}\right)$ in a 450 -foot $(137 \mathrm{~m})$ well drilled at an unknown time at Boyes Hot Spring site.

In the early part of 1982, the swimming pool facilities, and grounds at the abandoned Boyes Hot Springs site were completely bulldozed in preparation for the proposed construction of a multiple dwelling residential complex to be geothermally heated if proved feasible. All that remained at the springs site in the spring of 1982 were rubble and three visible abandoned water well heads.

\section{Other Possible Historic Geothermal Locales in the Sonoma Valley Area}

Some older literature describes two other "springs" in the Sonoma Valley area, but does not indicate a water temperature. It is not known if these sites are or were warm enough to be classified as geothermal, but they are listed below so that no clue to understanding the nature of the geothermal resources in Sonoma Valley is overlooked. These old sites have not yet been located by CDMG.

Waring (1915):

Ohms Spring - "About one-half mile southeast of Boyes Hot Springs is another drilled well whose water was used to some extent in 1909 for bathing. The property was open to the public under the name of Ohms Spring, and accommodations were provided for about 20 guests."

O'Donnell' Springs - "Two sulphur springs of relatively small flow that issues in a ravine on the west side of Sonoma Valley have been used for drinking for a number of years, and of late a small sanitarium has been established at the place. The water is not strongly mineralized, however, and the occurrence of the springs is not of unusual interest."

Bradley (1915):

O'Donnell's Sulphur Spring - "is near Glen Ellen."

Ohms Springs - "a drilled well 1/2 mile southeast of Boyes Springs. A small resort. Mrs. F. Shirley, Sonoma, owner."

Anonymous (1897):

O'Donnell's Mineral Springs - "Dr. C.C. O'Donnell's Mineral Springs, Glen Ellen, (are) the largest and most picturesque pleasure and health resort in California.

... owned by Dr. C.C. O'Donnell at 1206 Market Street, San Francisco, who acquired it seven years ago... At Glen Ellen are five mineral springs which have proved by analysis to be the 
greatest remedy for liver, stomach, and bladder complaints, rheumatism, catarrh and lung troubles...."

Development of Geothermal Wells

Since the late 1880 's, some wells have deliberately been driven into geothermal springs areas of Sonoma Valley to gain control over the discharge and increase production for resort use. Many wells were artesian as described above. Some, such as the early wells at the Boyes Hot Springs site, encountered methane(?) gas.

Other wells were drilled in the valley over the years to augment domestic and municipal water supplies. Occasionally these wells intersected warm water aquifers; some became artesian, also.

Plate $\perp$ shows the location of selected geothermal wells in the Sonoma Valley area. Some are artesian, but most of the older wells, such as at Boyes Hot Springs and Agua Caliente Springs, no longer naturally flow.

There are probably many more warm water wells in the Sonoma Valley area than have been located on Plate 1.

\section{Conclusions}

The maximum surficial geothermal resource temperature reported in historic literature for the Sonoma Valley area was at Boyes Hot Springs. Waring's 1915 account above reported $48^{\circ} \mathrm{C}\left(118^{\circ} \mathrm{F}\right)$ at Boyes Hot Springs. Most other historic accounts, however, set the maximum temperature of surface discharge from wells at Boyes Hot Springs at $44^{\circ} \mathrm{C}\left(112^{\circ} \mathrm{F}\right)$. The second "warmest" well was at Fetters Hot Springs with Bradley (1915) reporting $46^{\circ} \mathrm{C}\left(114^{\circ} \mathrm{F}\right)$ in the discharge.

Both of these areas along with Agua Caliente Springs are located in a "warm water belt" long known to exist in the area extending northwestward from the City of Sonoma. Comparing the older accounts above with data from Plate 1 , it appears that some surface water well temperatures have somewhat decreased over the years in this area. This is probably because warm water tables have "dropped" over the years as evidenced by the fact that old wells at these areas no longer are artesian and by the fact that the original springs at Boyes Hot Springs have "dried up" since Laizure's (1926) account above.

Interestingly, there are some newer wells that currently flow artesian (Plate 1 , Locations No. C-17 and C-29) in the southeastward extension of this "warm water belt" into the City of Sonoma.

The warmest down hole temperature previously reported in the literature was again at Boyes Hot Springs. Sylvester Associates (1982) show a $62.8^{\circ} \mathrm{C}\left(145^{\circ} \mathrm{F}\right)$ water

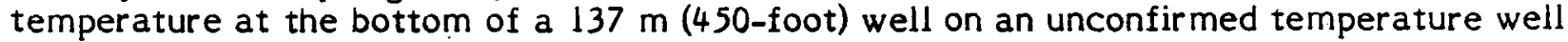
$\log$.

Comparison of water temperature from the historic literature indicates that the Boyes Hot Springs area contains the warmest geothermal resource so far found in Sonoma Valley. However, deeper well drilling elsewhere in the valley may someday encounter geothermal aquifers of higher temperatures. 
The water temperature of Morton's Warm Springs (Plate 1, Location No. C-4) may have increased a few degrees over the years since the early 1900's as the accounts above indicate. However, the apparent temperature increase may be the result of inaccuracies in thermometers, inconsistent measurement techniques, or time of year of measurement. At any rate, the flow of the geothermal resource at Morton's Hot Springs has certainly increased since the early 1900's with the drilling of wells at the site.

The geothermal resources underlying the Sonoma Valley may show some history of susceptibility to seismic activity. Waring (1915) reported above that the warm spring at the Sonoma State Hospital "broke forth. . at the time of the earthquake of April 18, 1906. . .". He also reported that some wells flowing since the 1890's at Boyes Hot Springs ceased flowing a short time after the April 18, 1906 earthquake. The "Regional Seismicity" section elsewhere in this report, lists three other accounts that may indicate that radical changes sometimes occur to the goethermal wells and springs after earthquake shocks are felt in the valley. 


\section{GEOLOGIC SETTING}

Introduction

The Sonoma Valley lies in the Northern Coast Range geomorphic province which is characterized by northwest-trending ranges and valleys. The Mayacmas Mountains on the east side of the valley separate the Sonoma Valley from the Napa Valley. The Sonoma Mountains lie between the Sonoma Valley and the Petaluma Valley and the Santa Rosa Plain to the west (Figure 1). The ranges in the Coast Range province are generally uplifted along faults.

The basement rocks in this area are composed of the Late Jurassic and Cretaceous Franciscan Complex and the contemporaneous Great Valley sequence. The Franciscan Complex of graywacke sandstones, shales, pillow basalts, radiolarian cherts, and glaucophane schists is considered to be oceanic and trench deposits which were subducted beneath the Great Valley Sequence, a fore-arc assemblage of graywacke sandstone and mudstone deposited upon ophiolitic volcanics, basic intrusives and serpentinite. The basement rocks are not exposed in Sonoma Valley.

\section{Stratigraphy}

\section{Petaluma Formation}

The oldest rocks exposed in Sonoma Valley are of the Piocene Petaluma Formation (Plate 2). The Petaluma Formation consists of light brown clays, siltstones, sandstones, clays, pebbly conglomerates, and minor nodular limestone. Brackish and fresh water fossils indicate a continental and estuarine depositional environment.

The Petaluma Formation is exposed along the west side of the Sonoma Valley along the base of the Sonoma Mountains and along Agua Caliente Creek in Sec. 30, T6N, R5W. In a road cut on O'Brian Road and along Agua Caliente Creek, the clay and siltstone is interbedded with diatomite.

Sonoma Volcanics

Osmont (1904), first applied the term Sonoma tuff to a section of tuffs and interbedded lava flows northeast of Santa Rosa. These tuffs overlie andesite flows which Osmont called the Mark West andesite. Above the tuff is a rhyolite unit which Osmont termed the St. Helena rhyolite. Dickerson (1922), applied the name Sonoma Group to all three units. Weaver (1949) grouped the Mark West andesite and Sonoma tuff into the "Sonoma Volcanics". He mapped the St. Helena rhyolite as a separate unit, although he considered it to be a member of the Sonoma Volcanics.

In the Napa area, Kunkel and Upson (1960) divided the Sonoma Volcanics into three members: (1) a lower undifferentiated member comprising andesite and basalt flows and andesite tuffs and breccias; (2) a middle diatomaceous member of water-laid tuffs, sandstones, conglomerates, and diatomaceous mudstones and siltstones; and (3) an upper member of welded tuffs and flows of rhyolite. Sickles (1974) used the three member division of the Sonoma Volcanics in mapping the area east of Kenwood and Glen Ellen.

In this report the Sonoma Volcanics is divided into two members, the lower undifferentiated Sonoma Volcanics member and the upper St. Helena rhyolite member (Plate 2). No middle diatomaceous member was identified in the study area. 
STUDY AREA

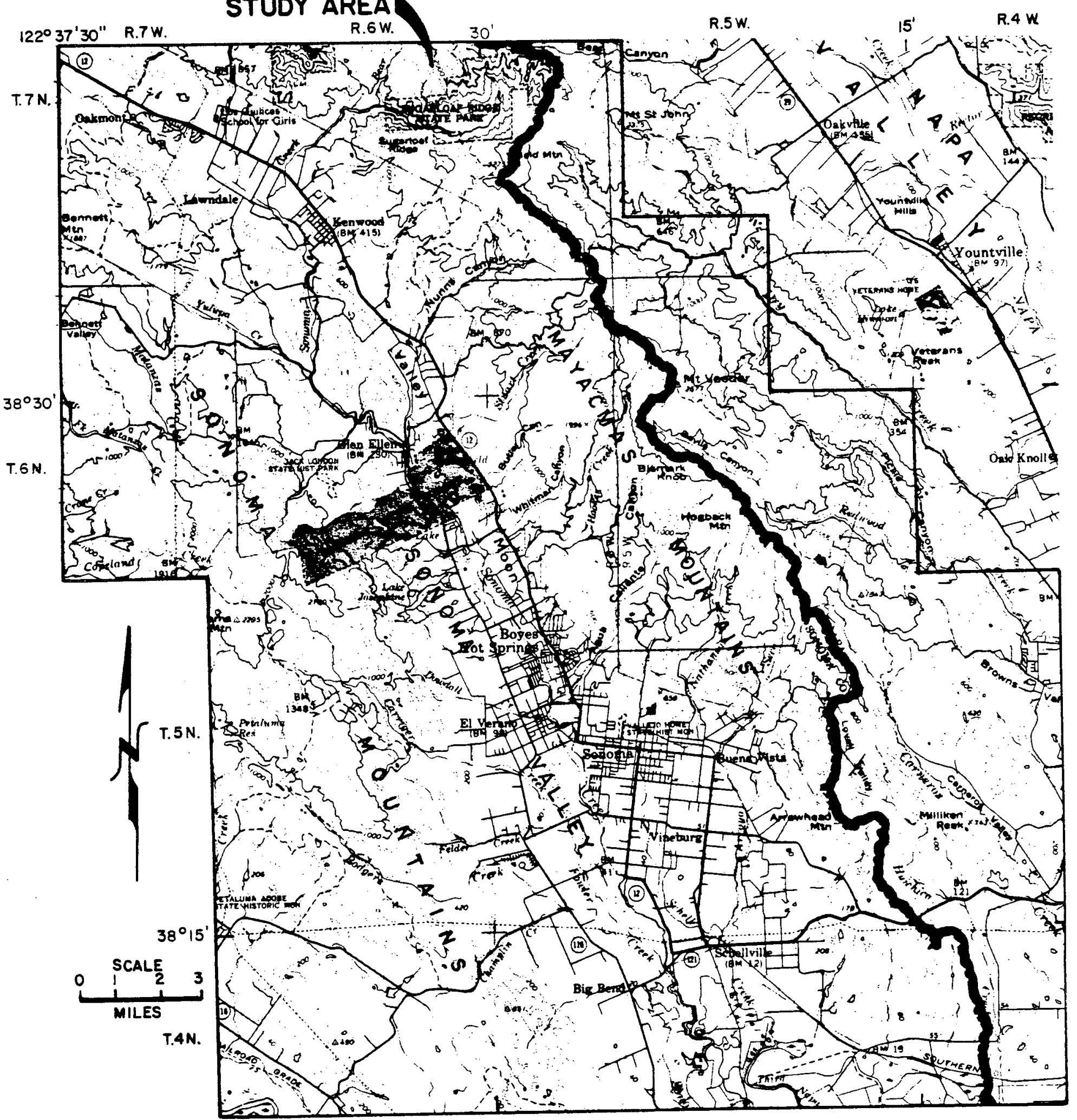

Figure 1. Location map of the Somona Valley study area. 
The Sonoma Volcanics are assigned an age of late Pliocene. The volcanics overlie the Pliocene Petaluma Formation and is overlain by the Huichica and Glen Ellen Formations of Pleistocene age (Kunkel and Upson, 1960). In the Napa area, the middle diatomaceous member has yielded floral assemblages of early late Pliocene (Axelrod, 1950; Kunkel and Upson, 1960). Potassium-argon age dates on the Sonoma Volcanics range from 5.3 m.y. to 2.9 to m.y. (Evernden and James, 1964; Mankinen, 1972).

Lower Undifferentiated Sonoma Volcanics. The base of the Sonoma Volcanics in this area is a heterolithic volcanic agglomerate. In the Agua Caliente Creek area, the basal agglomerate is interbedded with diatomite of the underlying Petaluma Formation.

The agglomerate is a water deposited volcanic breccia of angular clasts and coarse sand. A dark gray andesite typically forms clasts up to one meter across that are distinctively large than the other clasts. Cross bedding in the agglomerate is common and graded bedding occurs in some outcrops.

Overlying the agglomerate are flows of dark-gray to black andesite. The andesite typically forms massive, blocky outcrops but in some localities a platy jointing is developed parallel to the flow lamination. Euhedral phenocrysts of augite and plagioclase are common in the andesite. Rounded phenocrysts of olivine partially or completely altered to serpentine are less common. The ground-mass is predominently plagioclase microlites with augite and magnetite in a glassy matrix. These two units, the andesite and the underlying agglomerate, underlie most of the area mapped as Sonoma Volcanics.

Above the andesite is a deposit of red scoriaceous ash and breccia in which ribbon and spindle shaped volcanic bombs are common. This rock type is best exposed along Highway 12 south of Fetters Hot Springs. A similar red scoriaceous breccia is exposed at the Mountain Cemetery north of Sonoma and along Norrbom Road.

Interbedded pumiceous tuffs, andesite mudflow breccias, basalt flows and andesite flows overlie the red scoria. These rocks are best exposed north of Sonoma on Shocken Hill and along the ridge west of Norrbom Road and south of Mission Highlands. Also, they are exposed in Fetters Hot Springs and Agua Caliente beneath the St. Helena rhyolite.

St. Helena Rhyolite. The St. Helena rhyolite is composed mostly of welded rhyolitic ash flow tuffs. A common type is a porphyritic gray and pink laminar rock with phenocrysts of quartz and sanadine. Near the base of the unit is commly found a gray perlitic pitcnstone. The rock is porphyritic with phenocrysts of quartz and feldspar. Weathered joint surfaces typically show the laminar texture resulting from collapsed pumice fragments which bend around phenocrysts and lithic fragments.

The St. Helena rhyolite is exposed along the east side of Sonoma Valley where it has been down-faulted by a series of northwest-trending faults. It also crops out along the top of the Mayacma Mountains to the east of the area mapped. No exposures are found in the Sonoma Mountains on the west side of Sonoma Valley.

\section{Glen Ellen Formation}

The Glen Ellen Formation comprises poorly sorted alluvial clays, silts, sands and gravels in lenticular beds. Containing abundant clasts of andesite and obsidian, the formation was derived from erosion of the Sonoma Volcanics. No fossils have been found in the Glen Ellen Formation. Weaver (1949), considered the Glen Ellen to unconformably 
overlie the Sonoma Volcanics and hence, to be Pleistocene in age. Kunkel and Upson (1960) state that the Glen Ellen Formation interfingers with the uppermost beds of the Sonoma Volcanics and is late Pliocene to Pleistocene in age. Exposures of Glen Ellen Formation occur in the northern and western Sonoma Valley and along Sonoma Creek north of Sonoma.

\section{Huichica Formation}

The Huichica Formation is composed of alluvial beds derived from the erosion of Sonoma Volcanics. Comprising gravels, sands, clays, and reworked tuffs, the deposits rest unconformably upon the Sonoma Volcanics. Exposures of Huichica Formation occur in southeastern Sonoma Valley. Based on its stratigraphic position and similar lithology, it is probably Pleistocene in age and equivalent to at least the upper part of the Glen Ellen Formation.

\section{Structure}

The structure of the area is dominated by northwest-trending folds and faults. The Sonoma Valley is a graben-like structure bounded by northwest-trending, normal faults. The St. Helena rhyolite, which is exposed along the crest of the Mayacmas Mountains, is dropped by a series of normal faults to the valley floor on the east side of Sonoma Valley. On the west side of the valley, the Petaluma Formation and Sonoma Volcanics are uplifted to form the Sonoma Mountains.

A major fault, which runs the length of Sonoma Valley, was located by geophysical techniques. For the most part, the fault is buried by alluvium. Near Lake Suttonfield, on the Sonoma State Hospital grounds, the fault is exposed between Glen Ellen Formation on the west side and Sonoma Volcanics on the east. The sense of motion, west-side-down, is consistent with subsurface geophysical interpretation. Similarly, in the vicinity of Boyes Hot Spring and Fetters Hot Springs, Glen Ellen Formation is exposed in Sonoma Creek on the west side of the fault and Sonoma Volcanic rocks are found beneath the alluvium on the east side.

The importance of this fault to geothermal occurrence is emphasized by the fact that there is an alignment of thermal wells and springs located along the fault, mainly on the east side. Plate 1 shows the relationships of the thermal occurrences to the fault. The fault may be a conduit for the warm water and/or a ground water barrier for the warm water aquifer. 


\section{GROUND WATER HYDROLOGY}

Introduction

Ground water occupies and percolates (if not confined) through the pore spaces in water-bearing formations from zones of recharge toward zones of discharge. When geothermal fluids enter a ground water hydrological system either by ascending from depth along faults and fractures or from a lateral source, their movement is controlled by the same aquifer characteristics that govern fresh ground water movement. The knowledge of the behavior and characteristics of ground water in an area known to contain geothermal springs and near surface warm water aquifers may provide some insight into such geothermal reservoir characteristics as areal distribution, volume, depth to geothermal fluids, direction of fluids movement, and water quality. In the Sonoma Valley area the complex geologic structure and stratigraphy result in discontinuous, lenticular aquifers intercalated with nonwater-yielding units.

The major ground water studies of the Sonoma Valley area are Clark (1919), Kunkel and Upson (1960), Ford (1975), and Herbst (1982).

\section{Hydrologic Properties}

The oldest geologic unit in the Sonoma Valley area is the Franciscan Complex of Jurassic and Cretaceous age. This consolidated rock complex contains water only in fractures. Aquifer continuity in the Franciscan Complex depends on the extent that the fractures are interconnected. In essence, this unit has almost no specific yield, but Herbst (1982), assigns a specific yield of less than three percent and states that the water quality when developed from this formation is of poor quality in thermal areas.

The Petaluma, Glen Ellen, and Huichica Formations (described in the previous geologic setting section) have generally low but varying specific yields. All are assigned specific yields of three to seven percent by Herbst (1982). Water is often confined (artesian) in these formations. The water quality is generally good, but not as good as water developed from the alluvium and alluvial fan deposits of the valley.

The Pleistocene and Holocene alluvial fan deposits and alluvium deposits of the central and upper Sonoma Valley are the best aquifers. Their specific yields are variable, but range from moderate to high. Herbst (1982), assigned a specific yield of 3-15 percent for alluvium deposits and 8-17 percent for the alluvial fan deposits. Althought these are generally thin deposits, these units are the principal sources of fresh water in Sonoma Valley. The ground water is unconfined moving inward from the sides of Sonoma Valley and southward down the valley. Excess ground water discharges into Sonoma Creek and into the tidal sloughs tributary to San Pablo Bay.

The geologic unit that appears to have a direct bearing on the hydrology of geothermal fluids in Sonoma Valley is the Pliocene Sonoma Volcanics. This unit is a thick interbedded sequence of discontinuous andesite and basalt flows, tuff, welded tuff, breccia, pumice, scoria, and volcanic sediments with minor intrusive igneous rocks. The volcanic flow rocks are essentially nonwater-yielding with water contained only in fractures. Wells that penetrate the unwelded tuffs, scoria, and volcanic sediments are often good water producers, yielding moderate-to-large quanities of water often as much as several hundred gallons per minute (Kunkel and Upson, 1960). Therefore, a specific yield collectively assigned to the formation must be highly variable. Herbst (1982) reports the specific yield is $0-15$ percent. Ground water in the Sonoma Volcanics is frequently confined or semi-confined. The temperature of water from some wells known to be drilled in the Sonoma Volcanics in the valley ranges from $18^{\circ} \mathrm{C}\left(65^{\circ} \mathrm{F}\right)$ to more than $43^{\circ} \mathrm{C}$ 
$\left(110^{\circ} \mathrm{F}\right.$ ) (Kunkel and Upson, 1960). Although no drilling logs of the warm wells in the Sonoma area are readily available, it is likely that most, if not all, of the warm water wells are in units of the Sonoma Volcanics (Chapman and Chase, 1982).

Kunkel and Upson (1960) state the source of water in the Sonoma Volcanics "... is precipitation on the outcrop area, infiltration of water from streams that flow over the outcrop area, and probably, in some places where the head is low and confinement is not complete, downward seepage of water from the overlying formations." It seems also likely that some water probably enters the upper permeable units by upward movement of deeper confined geothermal fluids along faults and fractures.

Herbst (1982) declared that it was not possible to determine the extent of aquifer continuity nor to determine a volume of water storage in units of the Sonoma Volcanics because of the variable geology. However, in discussing the hydrological system as a whole, Herbst (1982) says that the volume of ground water stored in the Sonoma Valley has not changed much over time.

\section{Conclusions}

Geothermal fluids in the Sonoma Valley appear to be predominantly produced from permeable units of the Sonoma Volcanics. The predominate source of warm water is probably deep circulation of precipitation and runoff in the outcrop areas of the Mayacmas Mountains east of the Sonoma Valley and the Sonoma Mountains west of Sonoma Valley. Artesian flow of geothermal wells is due to penetration of confined and semi-confined permeable aquifers usually in the Sonoma Volcanics. When geothermal waters enter the near surface hydrological system of Sonoma Valley, their movement is the same as for fresh water; inward toward the center of the valley and southward down the valley. This general movement trend is locally perturbed by subsurface structural water barriers such as faults. It is impossible with the current data to estimate the volume of water within the units of the Sonoma Volcanics and therefore the volume of geothermal resources available in Sonoma Valley is uncalculatable. 


\section{GEOPHYSICAL INVESTIGATIONS}

Introduction

Geophysical surveys were undertaken by the California Division of Mines and Geology (CDMG) as a part of the Sonoma Valley geothermal investigation in order to provide additional information concerning the geothermal resources in the area. A regional gravity map (Chapman and Bishop, 1974), aeromagnetic maps (U.S. Geological Survey, 1974a; 1974b), and a geophysical study consisting of detailed ground magnetic, gravity, and electrical resistivity surveys (Chapman and Chase, 1982) were already available for all or parts of the area. Therefore, CDMG's geophysical work consisted for the most part of additional relatively detailed ground magnetic, gravity, and seismic refraction surveys. A discussion of each of these surveys and their interpretations follows.

\section{Gravity Survey}

\section{Purpose}

Gravity measurements provide information both on the regional geology and on local geologic features that might be related to the geothermal resources in the Sonoma Valley area. Both Franciscan rocks and some units of the Sonoma Volcanics might have relatively high densities in comparison with alluvium and other sediments and sedimentary rocks in this area (Chapman and Bishop, 1974, p. 3). Thus, these rock units might be mapped by gravity methods. Additional gravity measurements were made during this investigation to supplement those available from earlier studies and to provide both better regional coverage and more detail in the area.

\section{Equipment and Field Procedure}

Gravity measurements were made in the Sonoma Valley area using La Coste and Romberg geodetic meter G129. Elevations were obtained on detailed lines by surveying. Regional stations were read at spot elevations on U.S. Geological Survey 7-1/2 minute topographic maps. All gravity stations were referenced to a gravity base established at a bench mark near Sonoma State Hospital, which was referenced, in turn, to stations of the California Division of Mines and Geology gravity base station network (Chapman, 1966). Eleven lines of gravity traverses totaling about $24 \mathrm{~km}$ ( 15 miles) in length were obtained at a station spacing interval mostly of $122 \mathrm{~m}$ (400 feet) (Plate 3). In addition, 24 new stations were established at spot elevations in the area for regional coverage. Those gravity traverses and stations are in addition to eight traverses totaling $13.7 \mathrm{~km}(8.5$ miles) in length and 20 regional stations obtained during an earlier study (Chapman and Chase, 1982).

\section{Gravity Data}

All gravity data were reduced to complete Bouguer anomalies for a density of 2.67 $\mathrm{g} / \mathrm{cm}^{3}$ and referenced to the International-Ellipsoid of 1930. Terrain corrections were made manually out to a radius of $2.29 \mathrm{~km}$ from each station, and to a radius of $166.7 \mathrm{~km}$ (100 miles) by means of a U.S. Geological Survey computer program (Plouff, 1977). Plate 3 is the Bouguer gravity map of the area contoured at an interval of one milligal (mgal). This map includes all of the gravity data available in the area. Profiles of the detailed gravity traverses are shown in Figures 2-19.

Plate 3 and the regional gravity map by Chapman and Bishop (1974) show a broad, northwest-trending gravity low in the southern part of Sonoma Valley. This anomaly becomes narrower north of the City of Sonoma, but it continues to the vicinity of Agua 

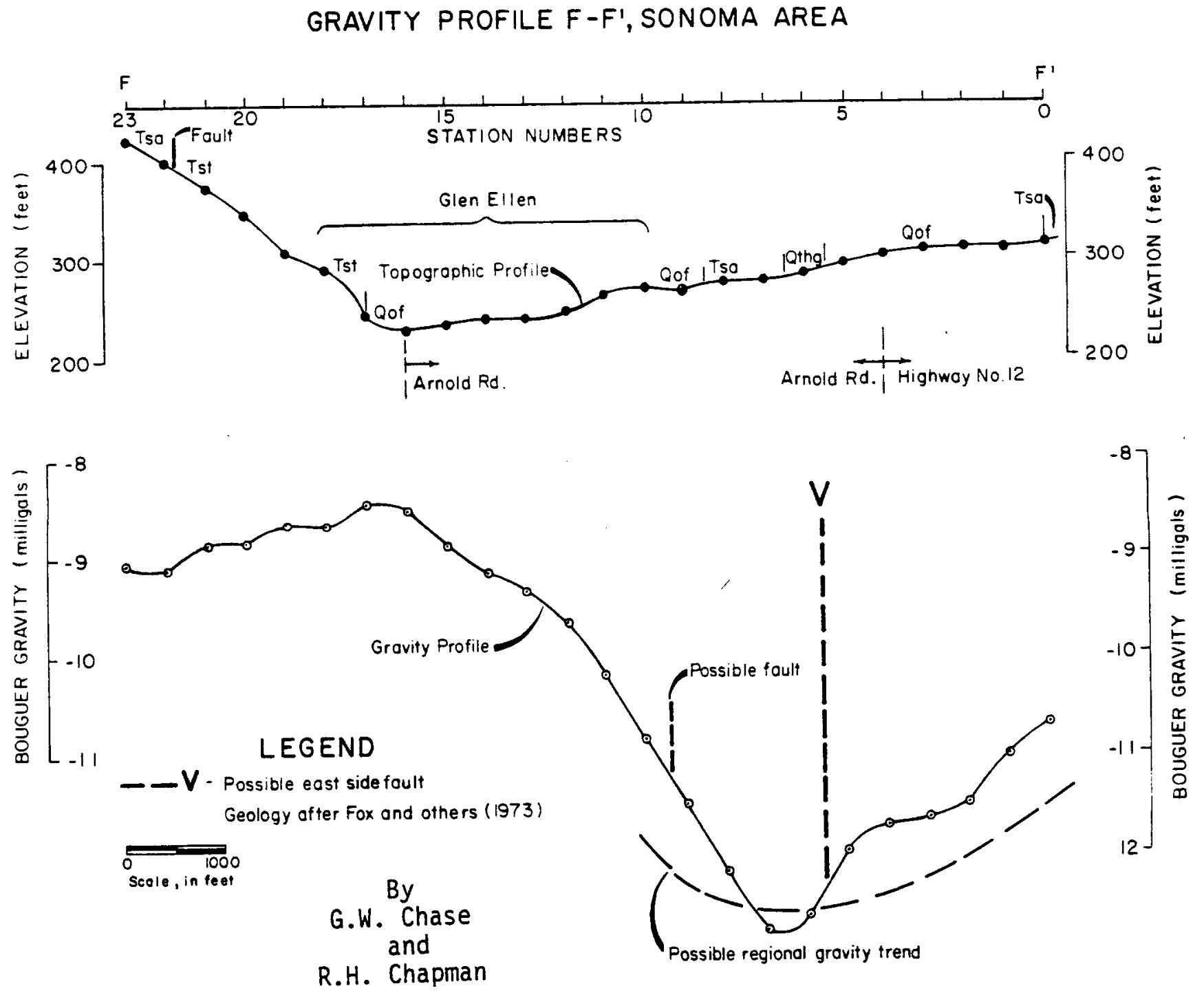

Figure 2. 
LINE G - G', SHOWING GRAVITY AND MAGNETIC PROFILES

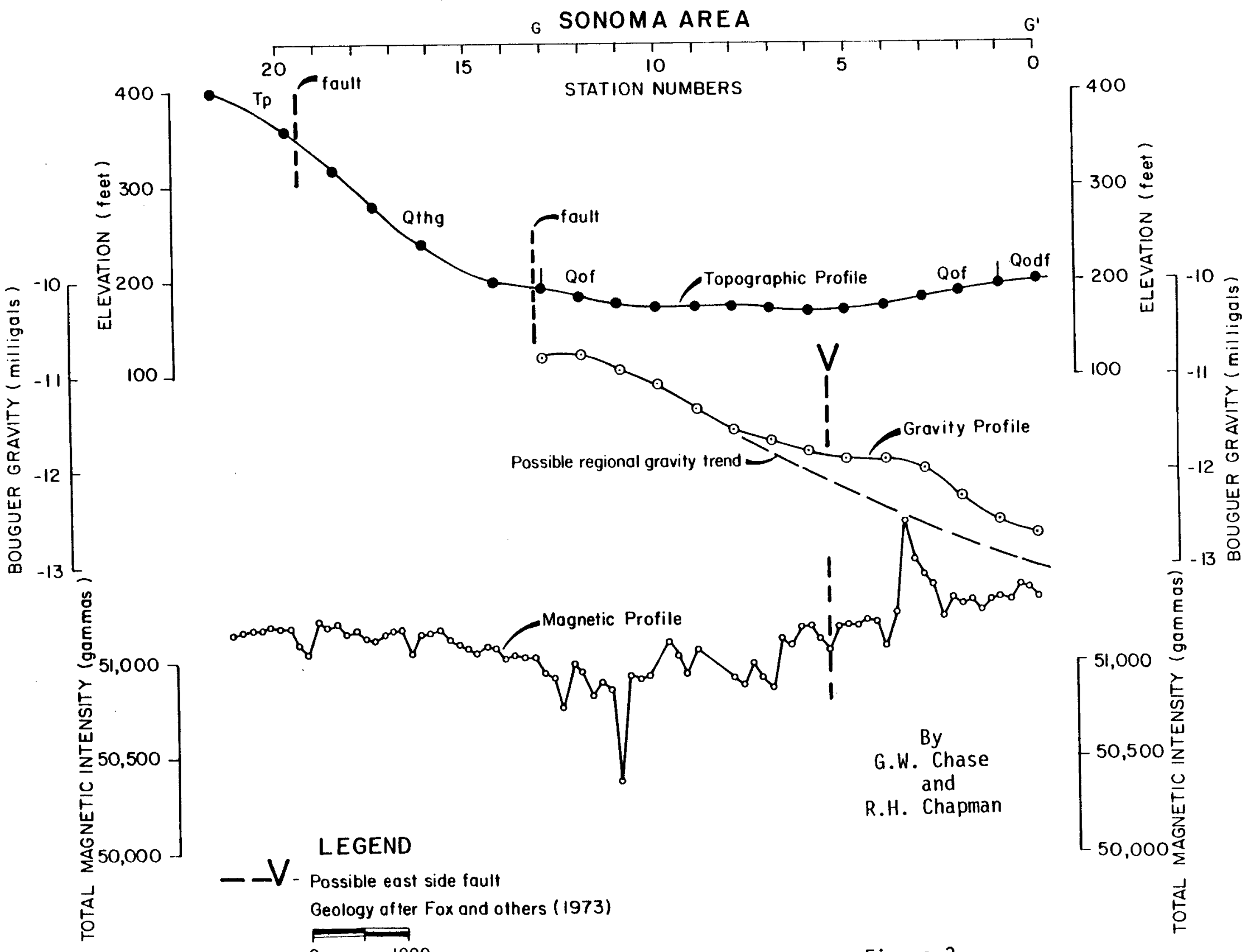

Figure 3. 


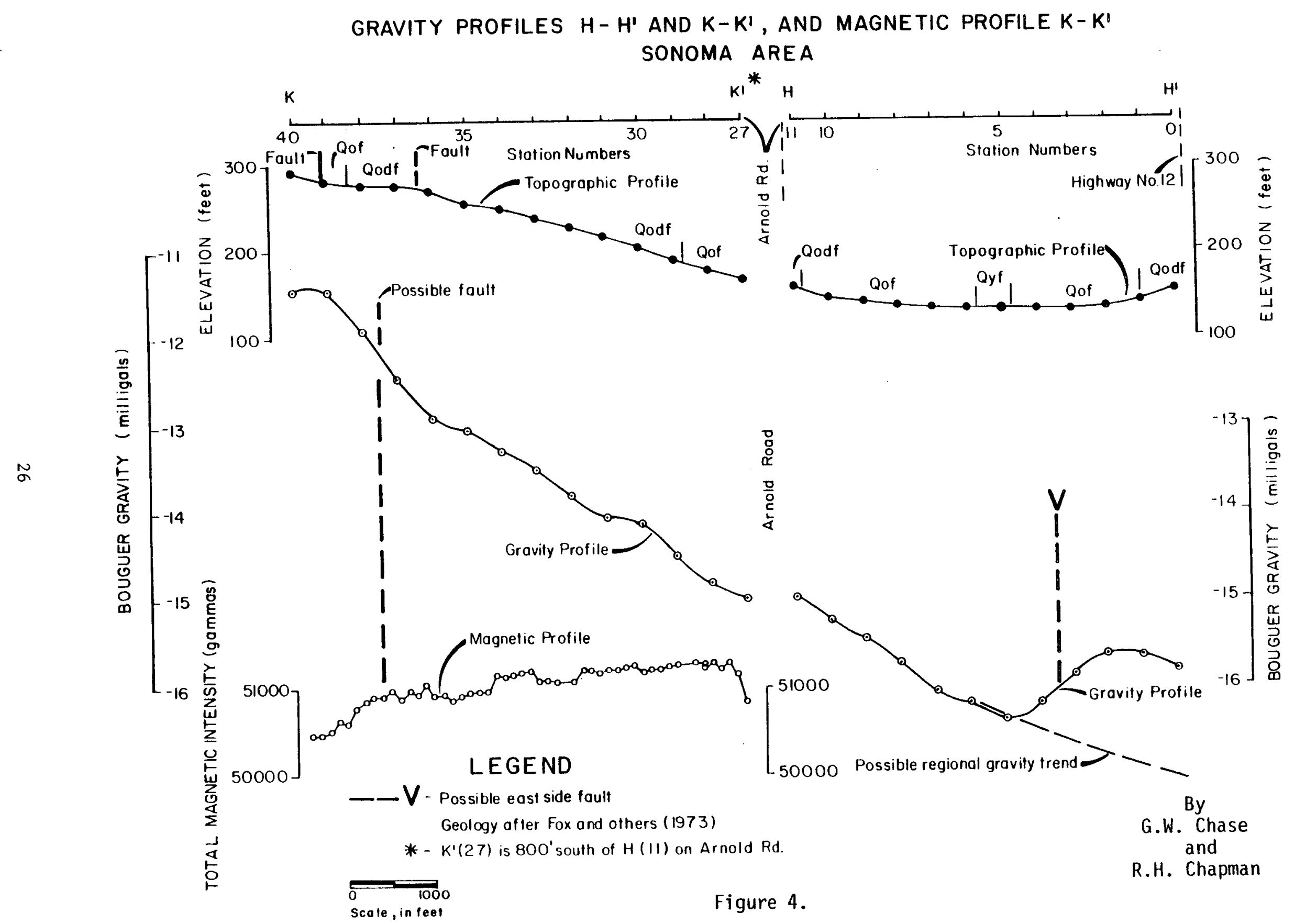




\section{RESIDUAL GRAVITY PROFILE H-H' AND INTERPRETATION SONOMA AREA

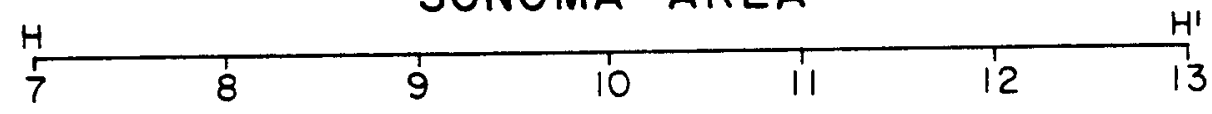

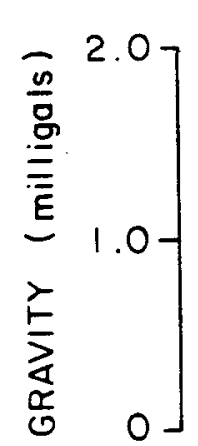
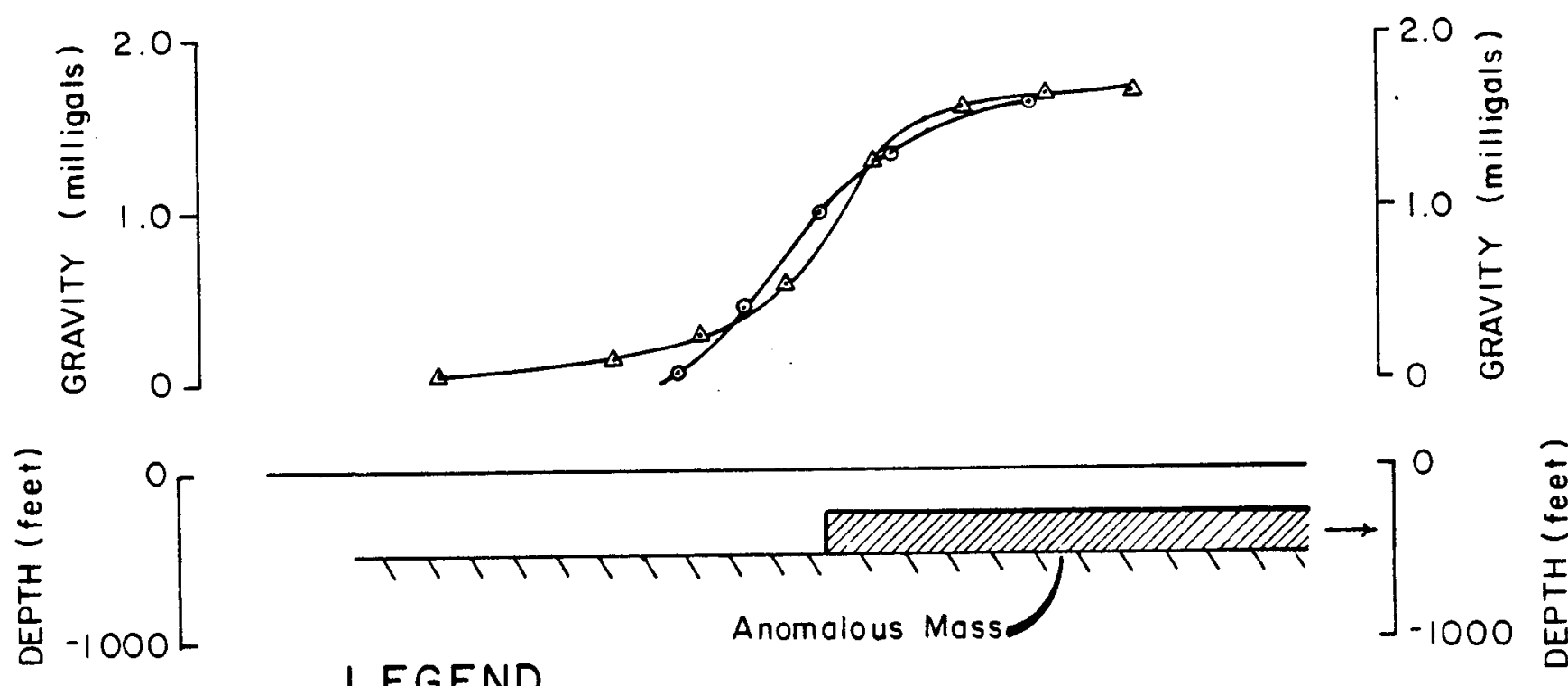

\section{LEGEND}

- Residual grovity profile

$\Delta$ Calculated gravity profile based on model with density contrast of $0.60 \mathrm{~g} / \mathrm{cm}^{3}$

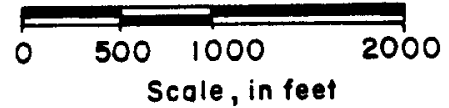
By
G.W. Chase and
R.H. Chapman

Figure 5. 
LINE $1-11$, SHOWING GRAVITY AND MAGNETIC PROFILES

\section{AND RESISTIVITY PSEUDO SECTION}
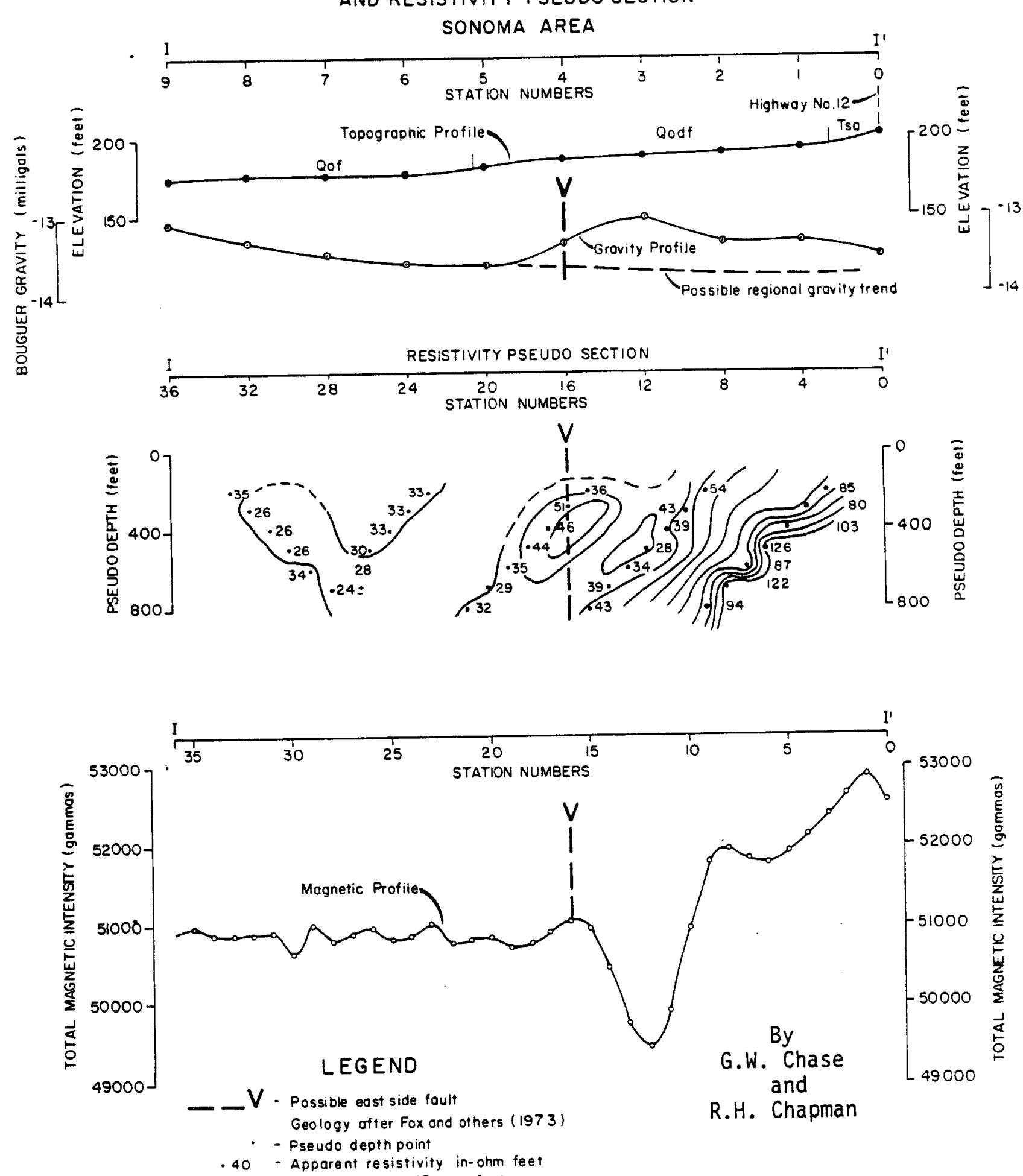

Figure 6 . 


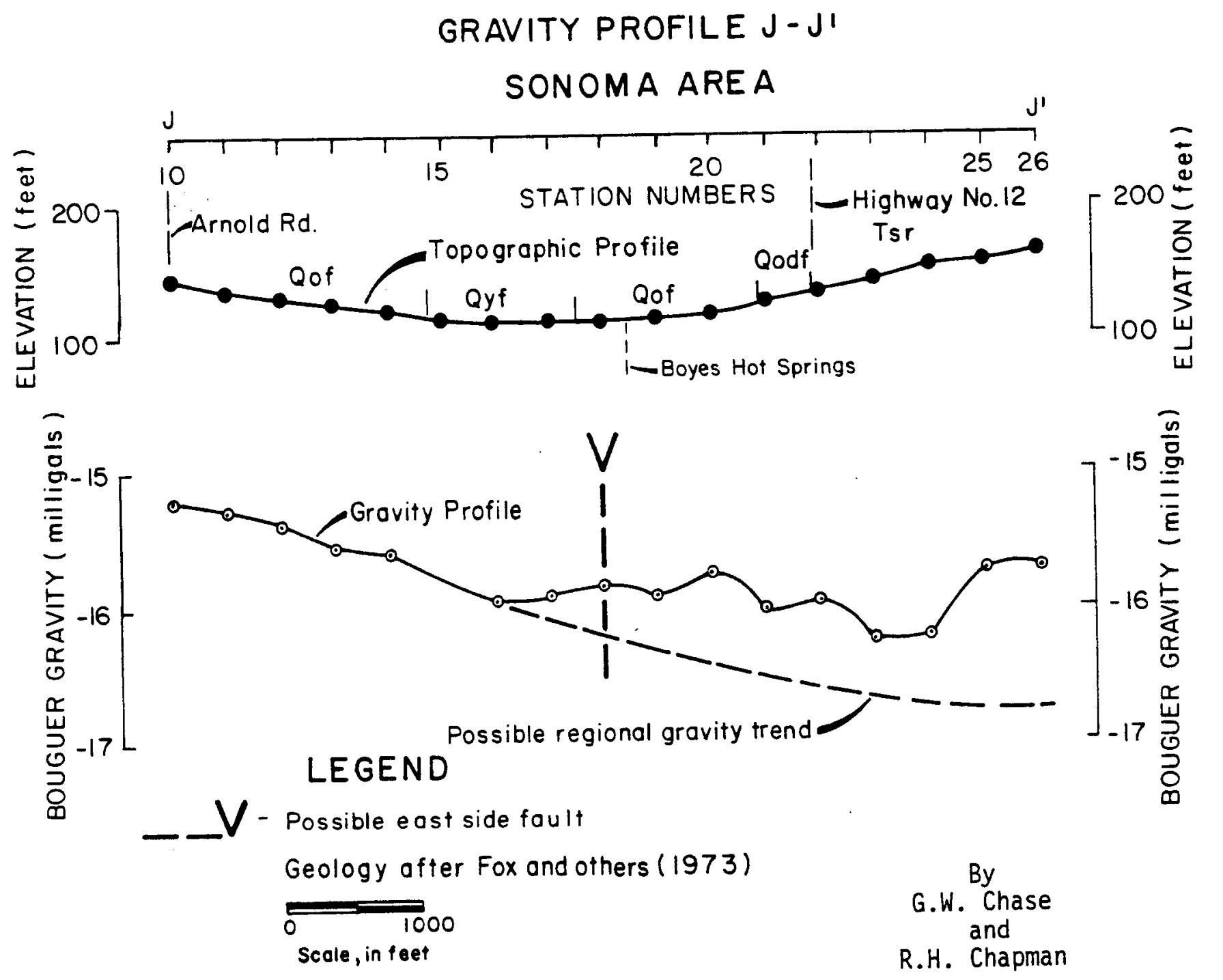

Figure 7. 
GRAVITY PROFILE L-L',SONOMA AREA

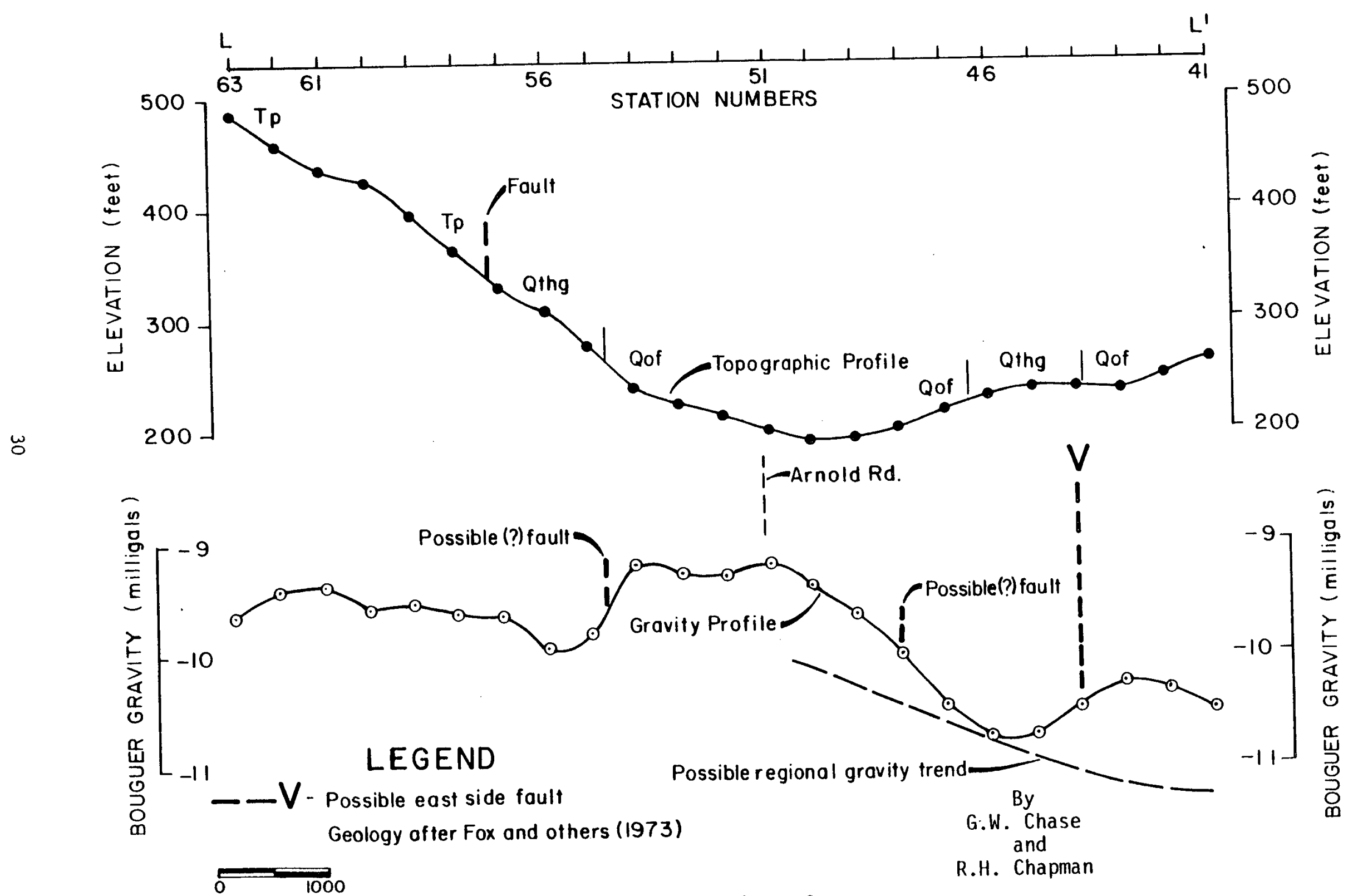

Figure 8. 


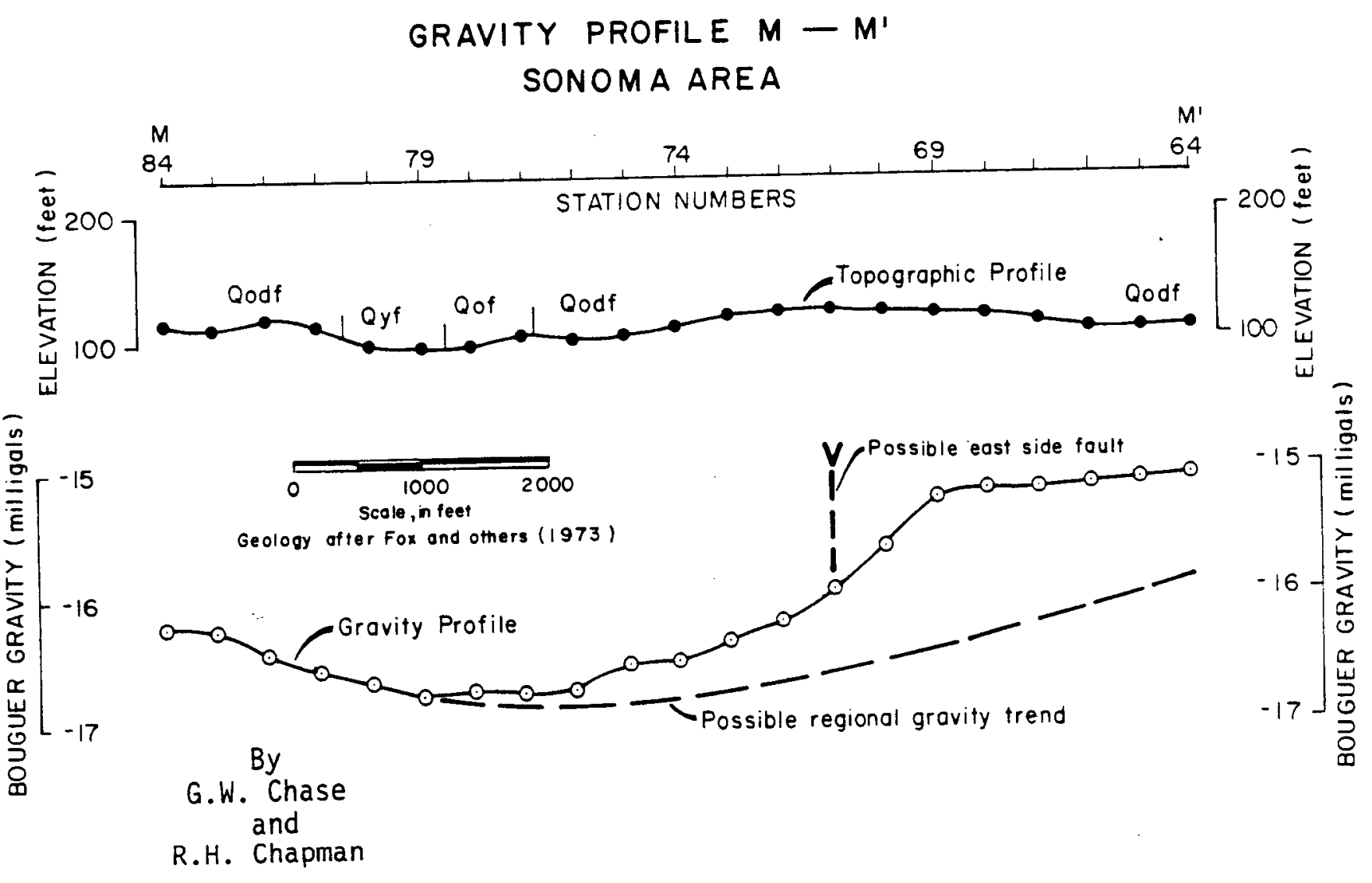

Figure 9. 


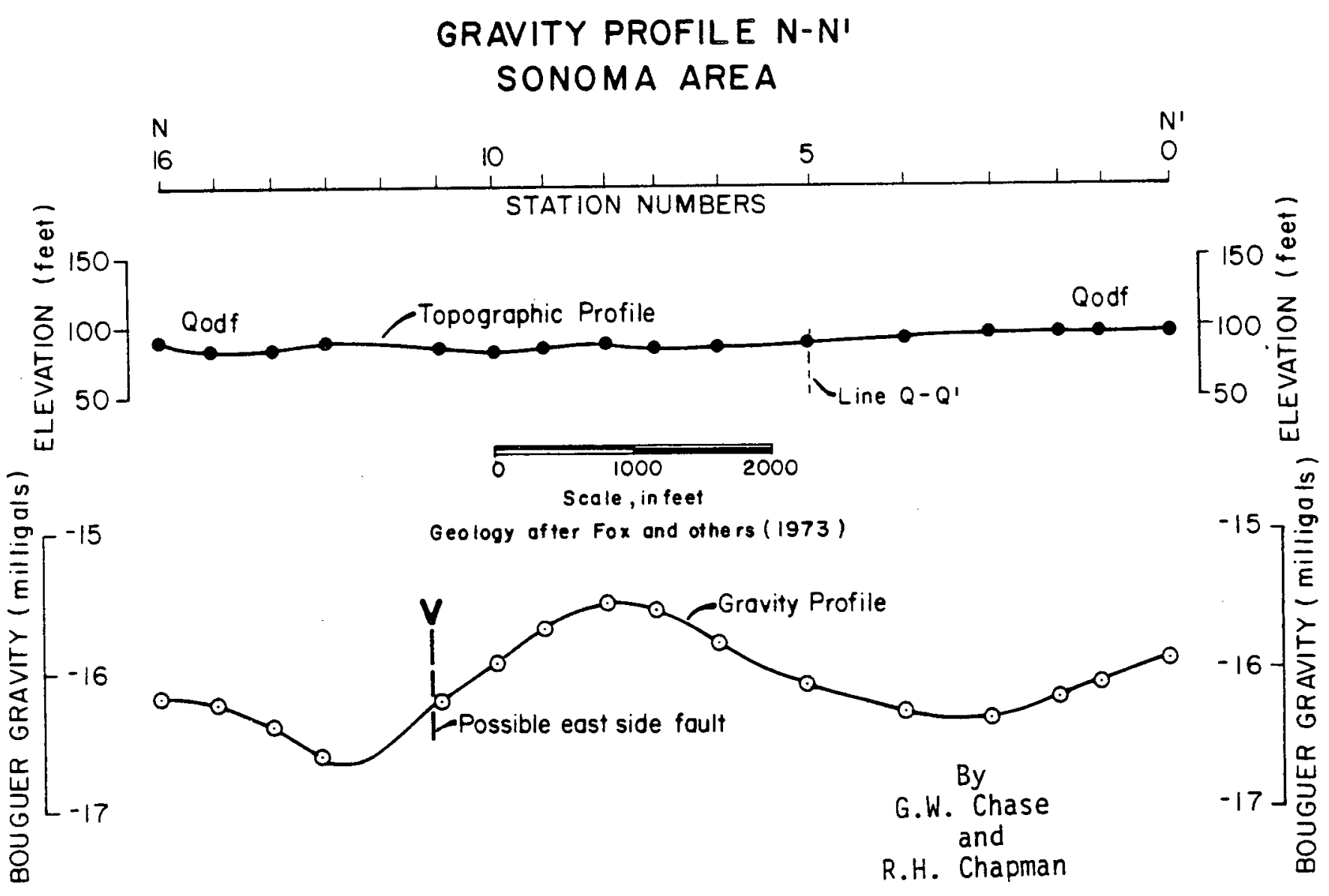

Figure 10. 


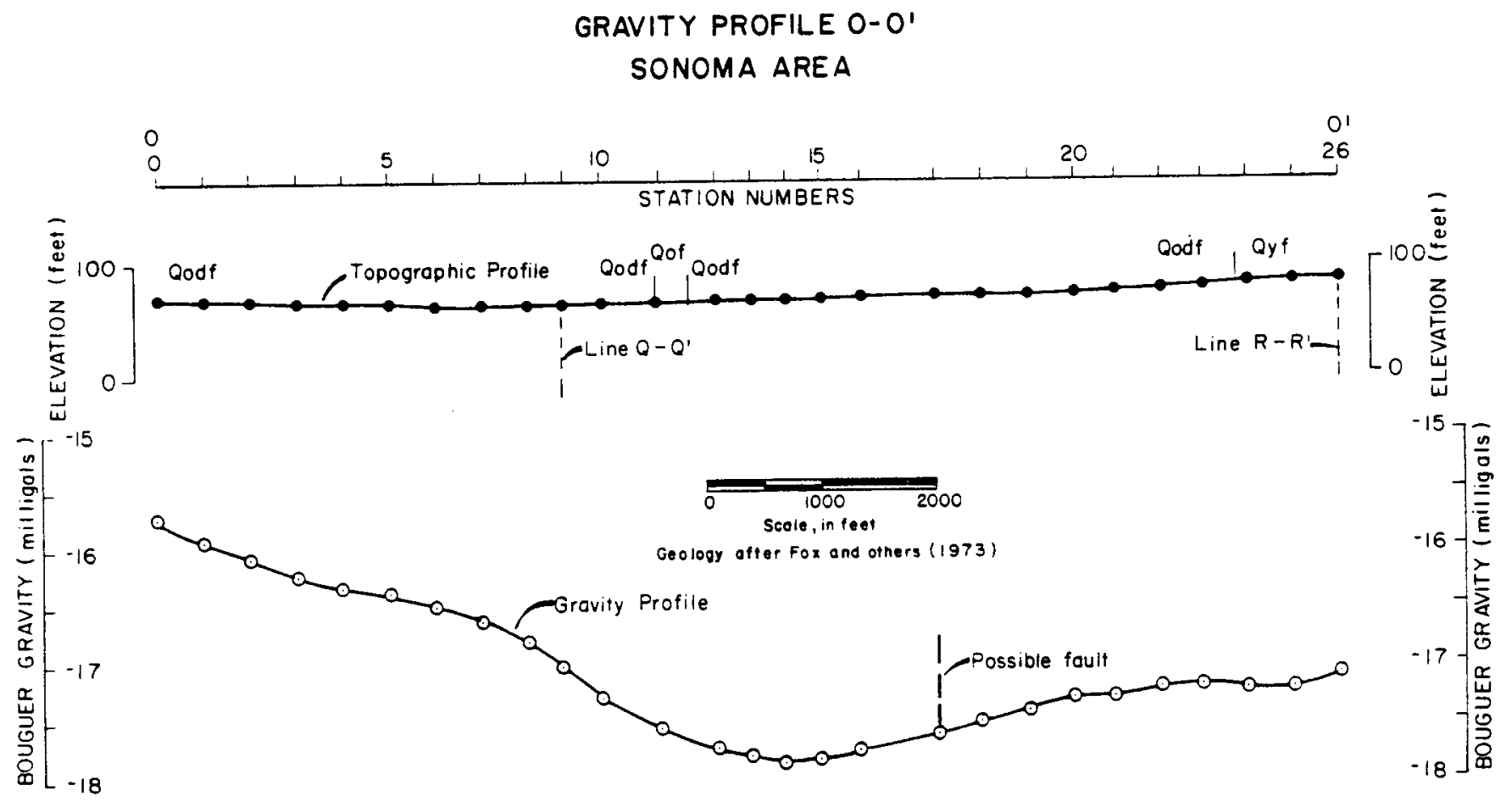

By

G.W. Chase and

R.H. Chapman

Figure 11. 


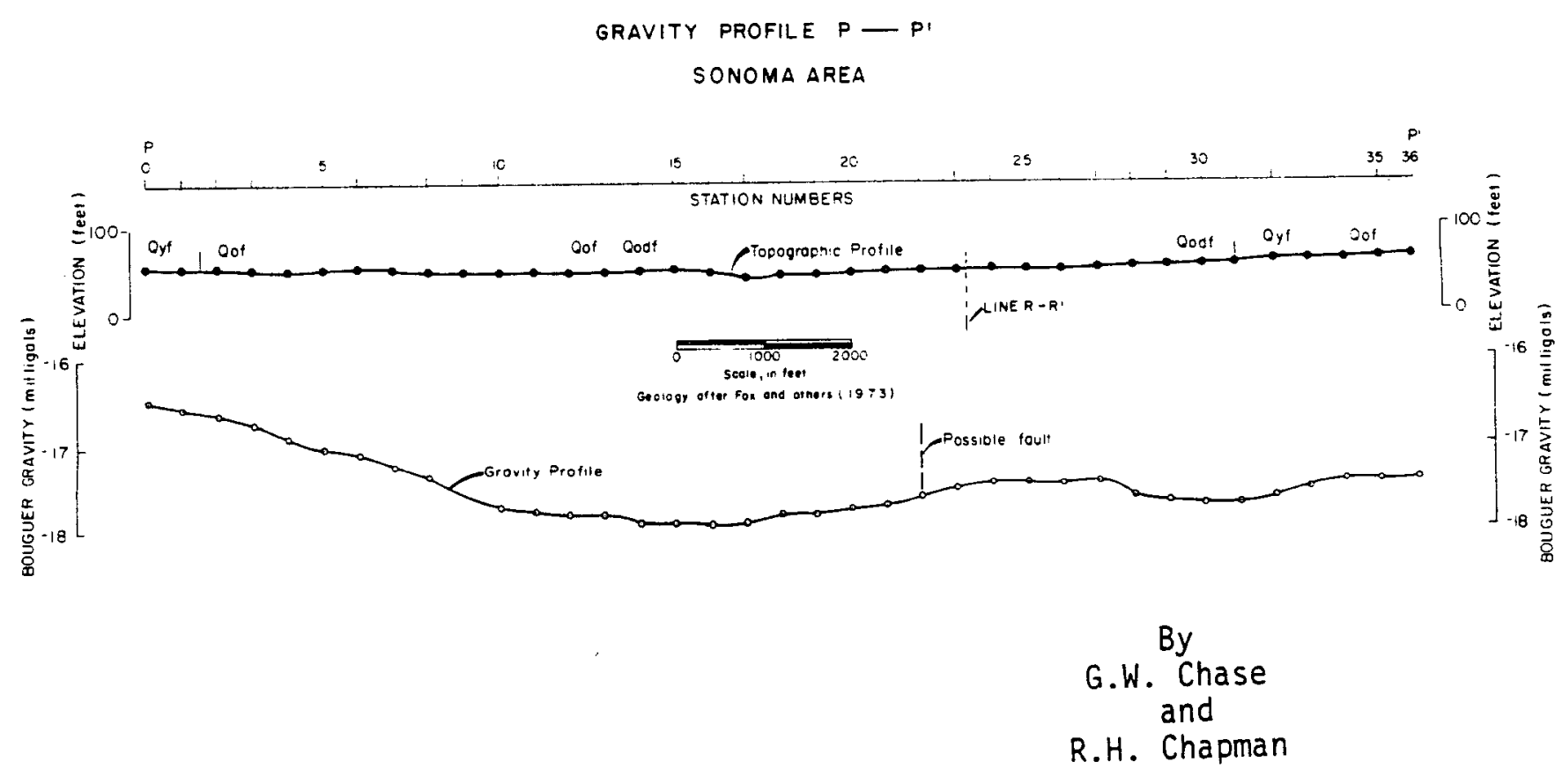

Figure 12. 

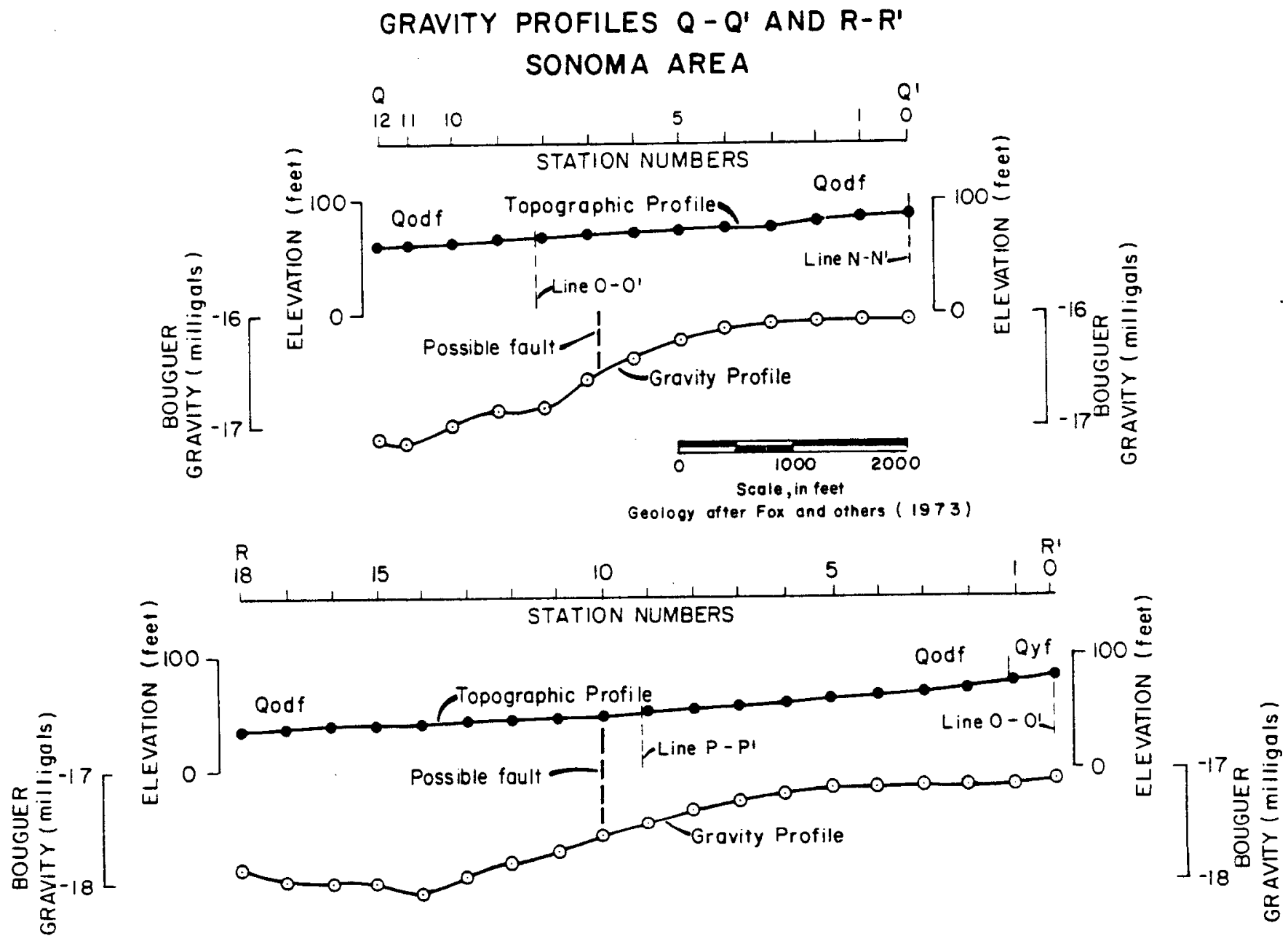

By

G.W. Chase

and

R.H. Chapman

Figure 13. 
LINE S-S', SHOWING GRAVITY AND MAGNETIC PROFILES

AND DIPOLE - DIPOLE RESISTIVITY PSEUDO SECTION

SONOMA AREA

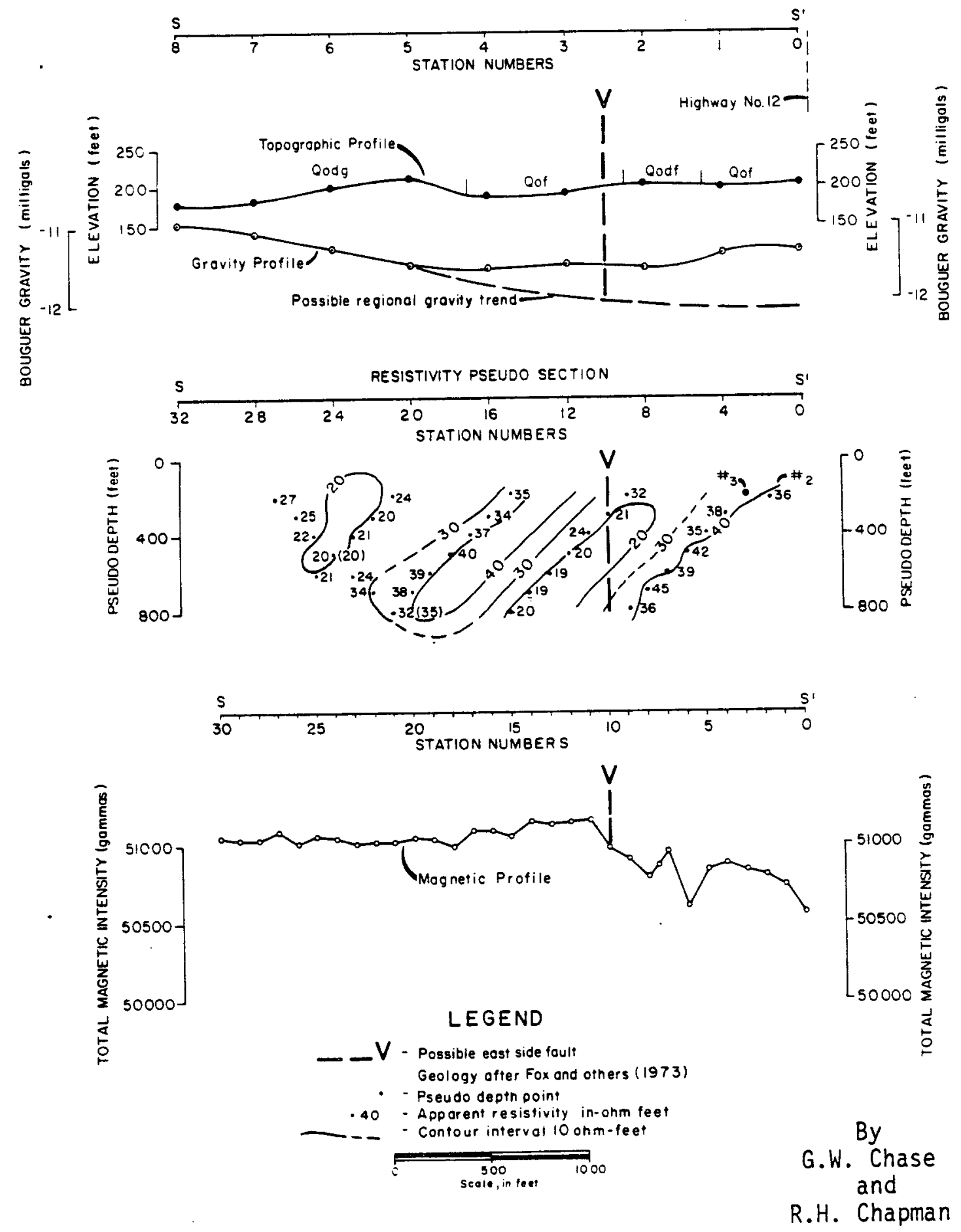

Figure 14. 


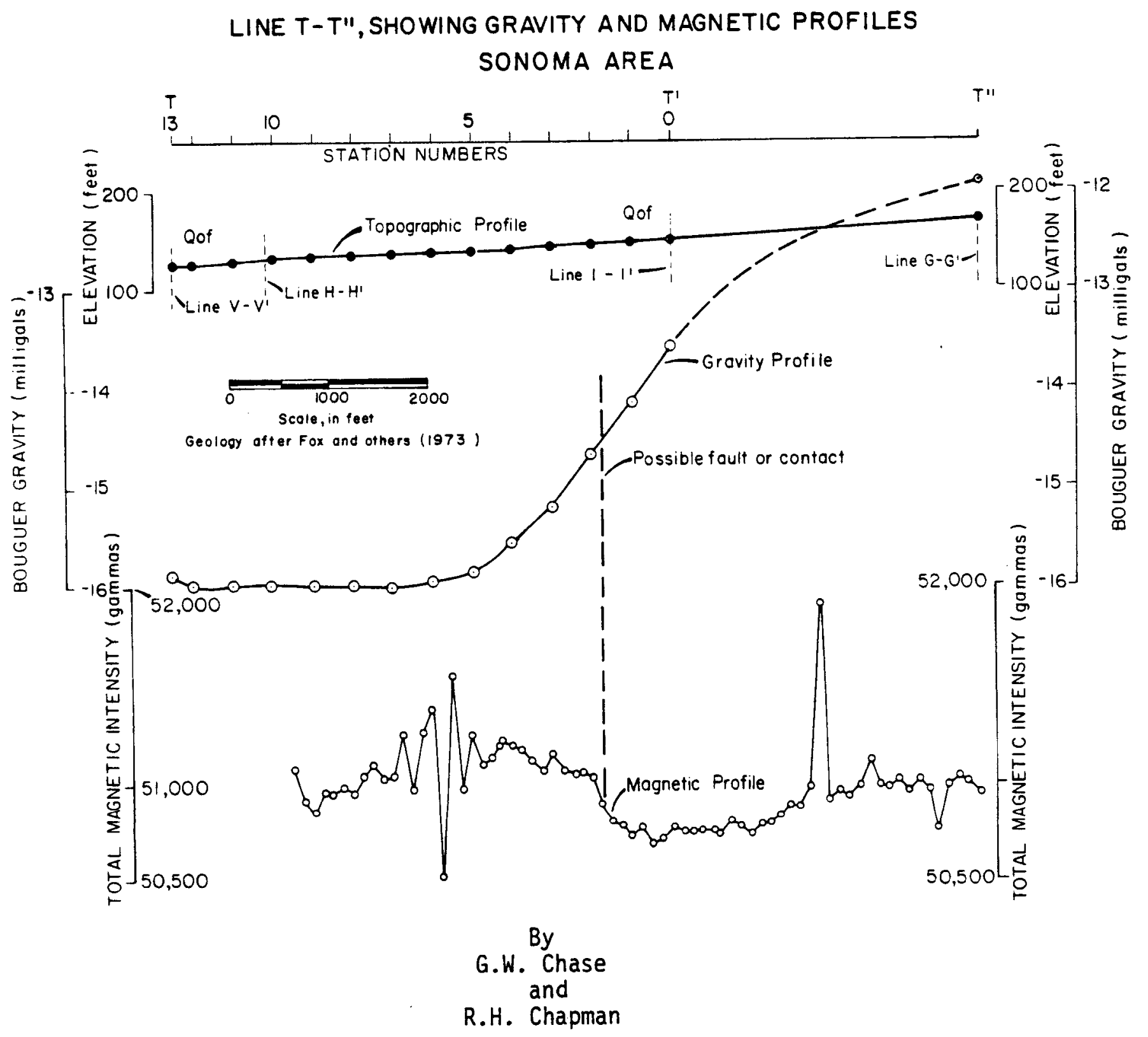

Figure 15. 
LINE U-U', SHOWING GRAVITY AND MAGNETIC PROFILES SONOMA AREA

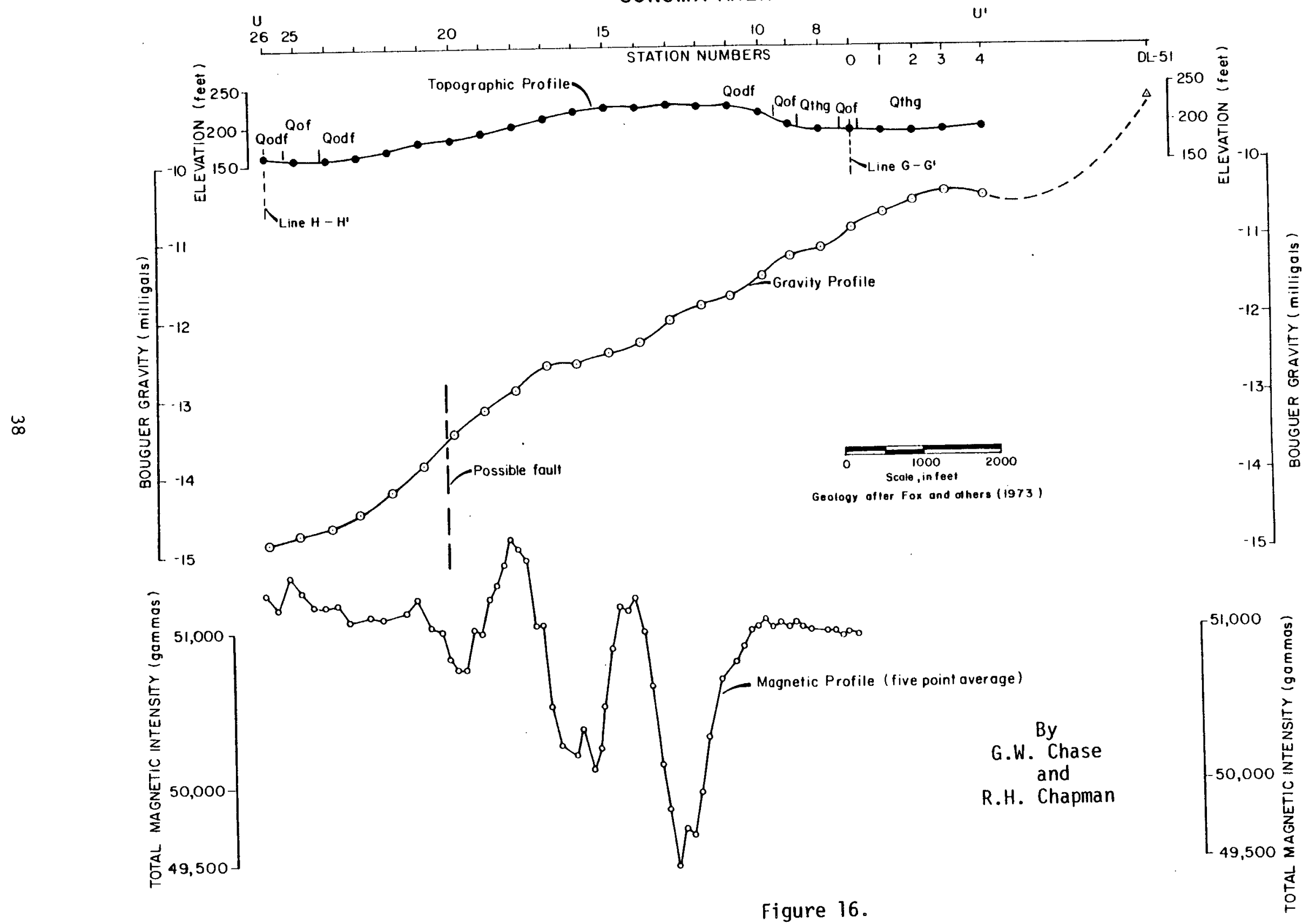




\section{LINE $V-V '$, SHOWING GRAVITY PROFILE AND SEISMIC REFRACTION SECTION}
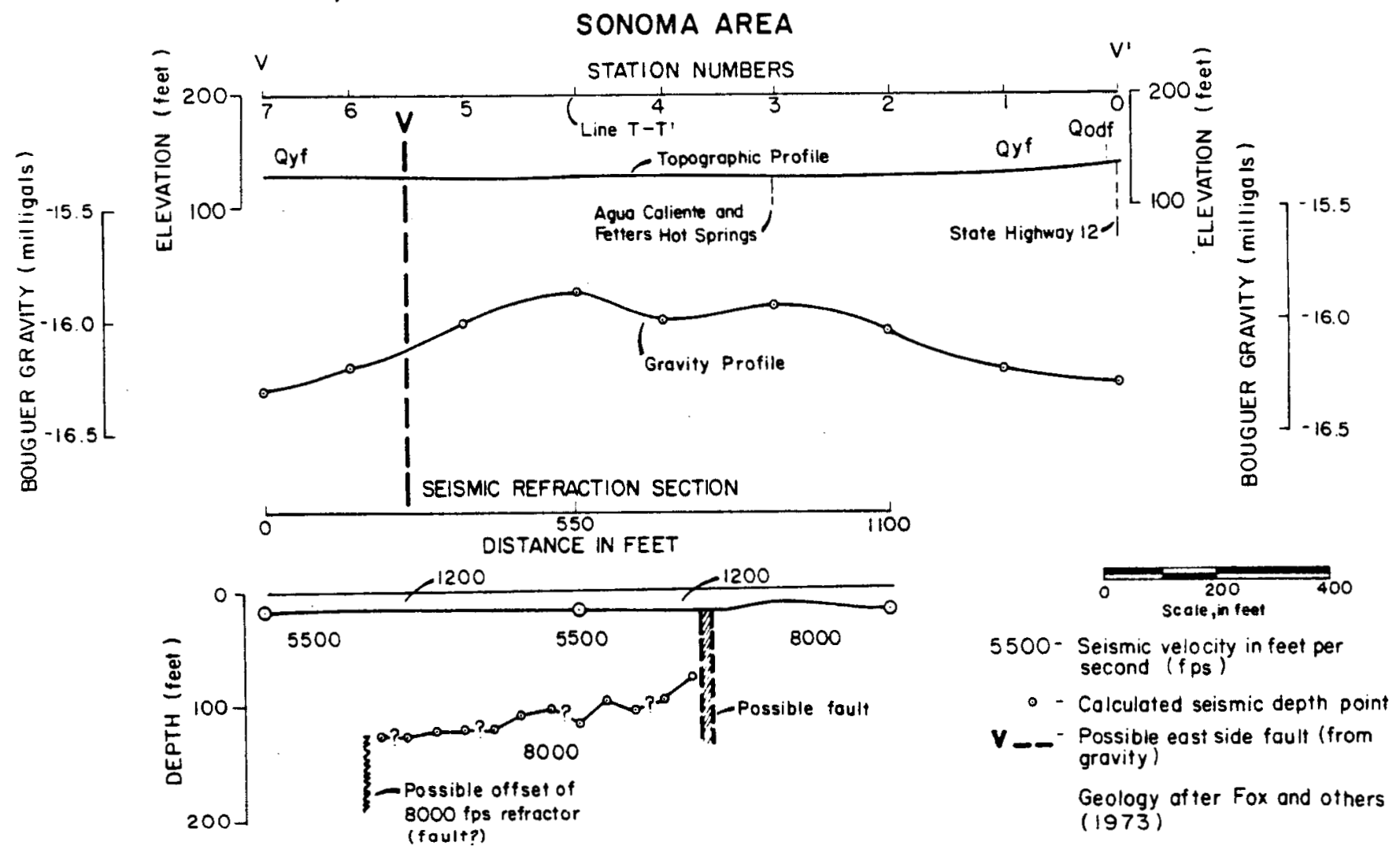

By

G.W. Chase

and

R.H. Chapman

Figure 17. 


\section{LINE W-W', SHOWING GRAVITY AND MAGNETIC PROFILES}

\section{SONOMA AREA}

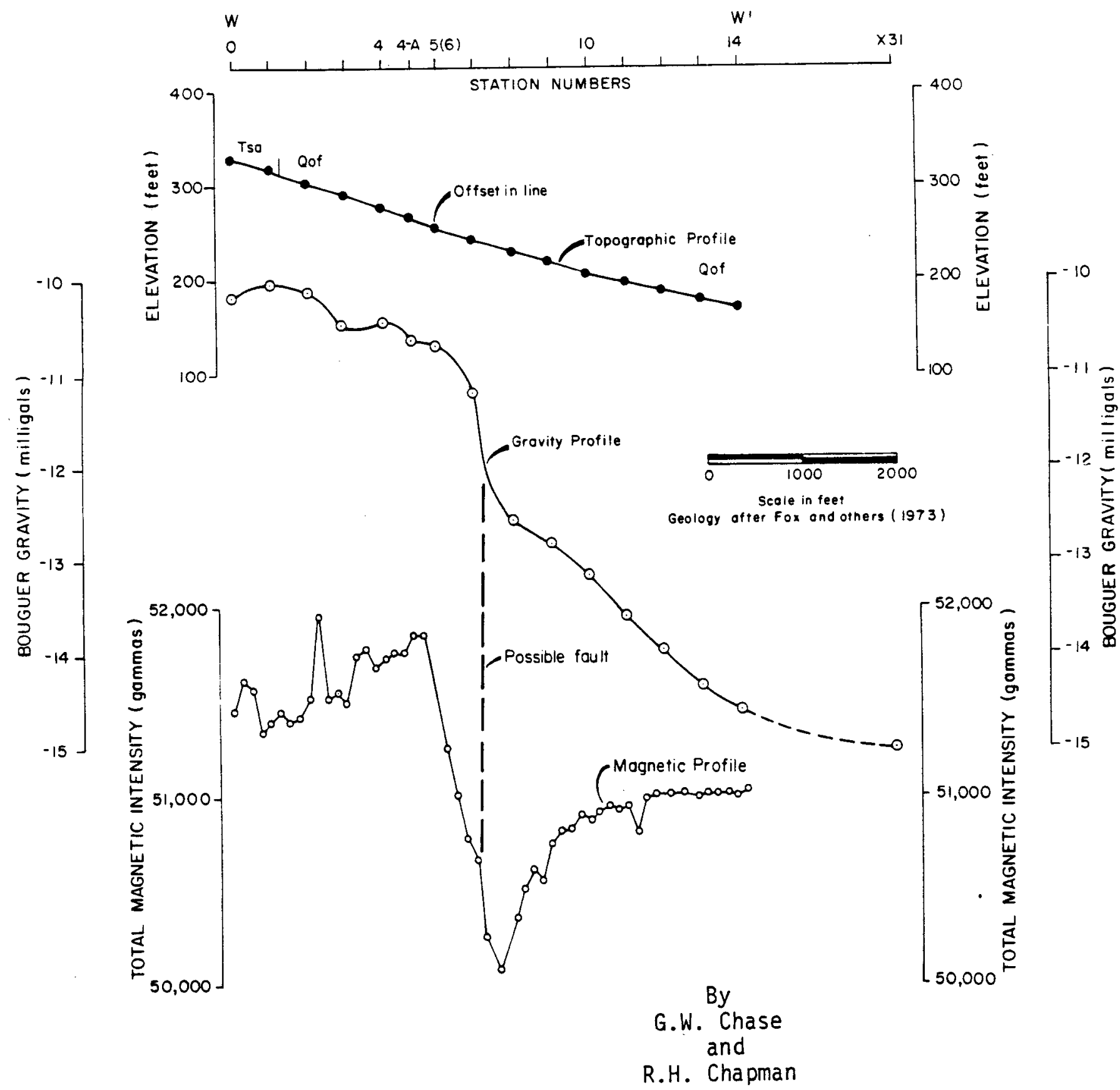

Figure 18. 
Caliente and Fetters Hot Springs. Based on scattered stations, from this point the gravity low trends northeastward into the hills on the northeast side of Sonoma Valley. A northeast-trending positive anomaly crosses the area near the town of Glen Ellen. This anomaly bounds the negative anomaly on the northwestern side. Northwest of Glen Ellen another nor thwest-trending negative anomaly marks Kenwood Valley (Plate 3).

Interpretation of Gravity Data

The prominent negative gravity anomalies associated with Sonoma and Kenwood Valleys on Plate 3 apparently represent structural basins that may be separated by a northeast-trending buried ridge near Glen Ellen. This possible ridge may be Franciscan basement rocks or possibly dense units of the Sonoma Volcanics. A positive aeromagnetic anomaly that corresponds approximately with the gravity anomaly in this area suggests that this ridge may consist at least in part of Sonoma volcanics (Plate 5).

Superimposed on the large scale gravity features are some relatively local anomalies that may correspond with geologic structure and, possibly, with geothermal resources. The detailed gravity profiles that define the local anomalies are located between Glen Ellen, on the north, and State Highway 121, on the south. These profiles cross parts of Sonoma Valley, mostly along east or northeast-trending lines. Most of the profiles that cross the eastern side of Sonoma Valley show a local anomaly that has the form of a small step (eastern side up) on the regional gravity gradient. This step ranges in amplitude up to about 0.75 mgal. The anomaly is especially apparent near station 44 on line L-L' (Figure 8), station 4 on line I-I' (Figure 6), station 3 on line H-H' (Figure 4) and station 10 on line $\mathrm{N}-\mathrm{N}^{\prime}$ (Figure 10 ). This anomaly can be interpreted as a fault where a relatively dense bed or layer is offset downward to the west, although there may be other possible interpretations. South of line $\mathrm{N}-\mathrm{N}^{\prime}$, this anomaly either terminates or it is shifted to the east approximately $610 \mathrm{~m}$ (2,000 feet) (Plate 3$)$. This apparent offset suggests a possible fault south of line $N-N^{\prime}$ with an east or northeast trend. The offset portion of the anomaly apparently continues toward the south at least as far as line P-P' and R-R' (Plate 3 and Figures 12-13), the southernmost gravity lines. A slightly curved dashed line marking the approximate location of the fault on the eastern side of Sonoma Valley (labelled "east side" fault) is shown on Plate 3.

In the vicinity of lines $\mathrm{H}-\mathrm{H}^{\prime}$ (Figure 4), J-J' (Figure 7), and $\mathrm{V}^{-\mathrm{V}^{\prime}}$ (Figure 17) the possible "east side" fault is close to the locations of the warm wells at Agua Caliente, Fetters Hot Springs, and Boyes Hot Springs. The fault is also close to a warm well on the Sonoma State Hospital property (Line L-L', Figure 8). All of these wells apparently are located within a distance of a few hundred feet east of the proposed fault.

A graphical residual anomaly was constructed for the gravity anomaly on line $\mathrm{H}-\mathrm{H}^{\prime}$ (Figure 5). Based on the residual anomaly, estimates were made for the depth to the center of the source and the thickness (offset), assuming a simple vertical fault, using the method of Nettleton (1976, p. 194-195). A density contract of $0.6 \mathrm{~g} / \mathrm{cm}^{3}$ was assumed for the difference between the Sonoma Volcanics and alluvium. The fault model obtained was then used to calculate a gravity anomaly by means of a two-dimensional gravity program (Haines and Campbell, 1979). The resulting calculated gravity anomaly is shown in Figure 5 for comparison with the residual gravity profile. The depth to the dense Sonoma Volcanics east of the fault was found to be about $76 \mathrm{~m}$ ( $250 \mathrm{feet}$ ), and the apparent vertical offset on the fault, also about $76 \mathrm{~m}$ (250 feet) (Figure 5). The figure on depth and offset are only approximate, and it may be that the depth of burial of units of the Sonoma Volcanics east of the fault is less than this if the density contrast is smaller. 
The gravity anomalies on some of the other lines such as L- $L^{\prime}$ (Figure 8) and $\mathrm{N}-\mathrm{N}^{\prime}$ (Figure 10) are similar in shape and amplitude to the anomaly on line $\mathrm{H}-\mathrm{H}^{\prime}$. Fault models for these anomalies probably would be very similar to that shown in Figure 5 . The anomalies on most of the remaining profiles are smaller in amplitude, however, and models for these probably would have smaller fault of fsets.

Profiles $W-W^{\prime}$ and $K-K^{\prime}$ (Plate 3 and Figures 4 and 18), on the west side of Sonoma Valley, each show a locally-steep gravity gradient that could represent a fault, possibly the same one. There is insufficient geophysical data to indicate whether or not this possible fault continues toward the north. The gradient on profile K-K' (between station 36 and 39), however, is close to two possible north-trending faults mapped by Fox and others (1973). Also, steep gradients on profile $U-U^{\prime}$ and $T-T^{\prime}$ (Plate 3 and Figures 15 and 16) could represent a northeast-trending branch of this or another fault. Profile $Y-Y^{\prime}$ (Plate 3 and Figure 19), located along State Highway 12, also has two steep gravity gradients that could represent faults that are shown on Plate 3.

Profile F-F' (Plate 3 and Figure 2) has a steep gravity gradient located approximately between stations 8 and 11 , just east of Calabazas Creek in Glen Ellen. This gradient may confirm the concealed north-trending fault shown in the area by Fox and others (1973). The narrow, northwest-trending, negative gravity anomaly shown in the vicinity of Glen Ellen on Plate 3 may represent a downfaulted block or graben between this possible fault and the "east side" fault on the eastern part of profile F-F'. The possible fault between Stations 8 and 11 on profile F-F' might project southward to a similar gradient near station 48 on profile L-L' (Figure 8), but it is difficult to trace beyond this line. It is possible, however, that this fault trends southward along the west side of the valley, and it could conceivably correlate with the possible fault shown on lines K-K' (Figure 4), and W-W' (Figure 18).

Profile L-L' (Figure 8), also shows a sharp, local gravity gradient near station 55 at the base of a hill on the west side of Sonoma State Hospital. This gradient could represent a fault, but the hill is composed of low-density rocks of the Glen Ellen Formation and the Petaluma Formation which might also cause this anomaly.

Most of the known geothermal resources in the Sonoma Valley area are found on the northeast side of the valley apparently east of the possible "east side" fault. Warm water having a temperature of about $52^{\circ} \mathrm{C}\left(125^{\circ} \mathrm{F}\right)$ has also recently been reported in volcanic rocks at a depth of about $442 \mathrm{~m}(1,450$ feet) in a drill hole at Sonoma State Hospital. Whether this latter occurrence of a possible geothermal resource is related to nearby faults or whether it characterizes the Sonoma Volcanics unit in this part of the area is not known. If geothermal resources are found in other parts of the valley, however, some of the possible structures mentioned above may aiso prove to be important.

Residual gravity values for a part of the Sonoma Valley area were obtained by subtracting a smoothed regional gravity map from a map of the Bouguer gravity values (Plate 3). Plate 4 is the resulting residual gravity map contoured at an interval of 0.2 mgal. Because the regional trends have been removed from the data of Plate 4 , the local anomalies are more apparent on this map. The approximate locations of possible faults in this part of Sonoma Valley, based on geophysical data, are also shown on Plate 4.

One of the most prominent features of the residual gravity map is the proposed "east side" fault, which generally marks the transition between positive residual anomalies, on the east, and negative residual anomalies, on the west. Another feature is the narrow 
northwest-trending negative anomaly east of Glen Ellen and Sonoma State Hospital that may represent a graben between the "east side" fault and another subparallel fault to the west.

\section{Magnetic Surveys}

\section{$\underline{\text { Purpose }}$}

Measurements of the earth's magnetic field are often useful in studies of the geology of areas that have relatively magnetic rock units. Units of the Sonoma Volcanics, some of which are known to be magnetic, are exposed in extensive areas around Sonoma Valley and probably underlie parts of the valley. Therefore, it is possible that some of these units can be mapped by magnetic geophysical methods.

Published aeromagnetic maps (U.S. Geological Survey, 1974a, 1974b) include the Sonoma Valley area. These maps provide an overall view of the magnetic anomalies in the vicinity. Ground magnetic data were also obtained during this study in order to provide more detailed information.

\section{Aeromagnetic Data}

The aeromagnetic maps (U.S. Geological Survey. 1974a, 1974b, and Plate 5) indicate that there are large magnetic anomalies in the Sonoma Valley area. Relatively local features include a north-trending positive anomaly mostly over exposures of Sonoma Volcanics east of the central part of Sonoma Valley, and an adjoining negative anomaly that includes part of the valley and some of the hills on the western side. The steep magnetic gradient that trends approximately north between the two anomalies may represent a contact on the eastern side of the valley. This contact may separate Sonoma Volcanics, on the east, from sediments or sedimentary rocks on the west, in at least part of the area. These anomalies extend southward with a smaller amplitude to a point about $1.6 \mathrm{~km}$ ( $1 \mathrm{mile}$ ) southwest of the City of Sonoma, so Sonoma Volcanics may be present within the valley here. There is also a local positive gravity anomaly in the same general area (Plate 3). Near Glen Ellen, a postive aeromagnetic anomaly crosses Sonoma Valley in a direction just south of east. This anomaly may correspond with the gravity anomaly that crosses the valley in the same general area, although there are some differences in the locations and trends of the two anomalies. These anomalies could be caused by buried, dense and magnetic volcanic rocks. The aeromagnetic data are not sufficiently detailed, however, to be of much use for a study of the geothermal resources of the area.

\section{Equipment and Field Procedures for Ground Survey}

Approximately $9.8 \mathrm{~km}(6.1$ miles) $(5$ profiles) of total-intensity ground magnetic traverses were obtained by CDMG in the Sonoma area during this survey. This is in addition to $8.6 \mathrm{~km}$ ( 5.4 miles) (6 profiles) of similar data obtained in the same general area during an earlier survey (Chapman and Chase, 1982). All of these data were obtained with a Geometrics model 816 proton-precession magnetometer, which has a reading sensitivity of one gamma. Stations along lines were spaced at intervals of $30 \mathrm{~m}$ (100 feet), usually estimated by pacing. On these profiles, it was necessary to avoid cultural features, such as pipes and all kinds of iron and steel objects that cause magnetic interference. Because of this problem, it was not possible to obtain usable data in much of the area, including the grounds of Sonoma State Hospital and the vicinity of the known geothermal resources at Boyes Hot Springs, Agua Caliente, and Fetters Hot Springs. 
Interpretation of Ground Magnetic Data

The ground magnetic data were plotted in profile form and the locations of the lines are shown on Plate 3. Most magnetometer lines follow northeast-trending roads and trails although a few follow roads that parallel the trend of the valley. The lines were run on both sides of the valley, in order to locate possible faults and other geologic structures that might be related to geothermal resources.

Magnetic profiles G-G' (Figure 3), K-K' (Figure 4), W-W' (Figure 18), U-U' (Figure 16), MA-MA' (Figure 20), MB-MB' (Figure 21), and MC-MC' (Figure 22) are located at least in part on the west side of Sonoma Valley (Plate 3). Some of these profiles, including G-G', $K-K^{\prime}$, and $M B-M B^{\prime}$ are relatively featureless, probably because volcanic rocks either are not present or are deeply buried in this part of the area. Magnetic values decrease near the western end of profile $K-K^{\prime}$ and show irregular anomalies near the western end of profile MA-MA', however, close to the location of units of the Sonoma Volcanics. Magnetic profile $W-W^{\prime}$ (Figure 18), in particular, and possibly profile MC-MC' (Figure 22), show evidence for the presence of a fault that offsets units of the Sonoma Volcanics on the west side of the valley (Plate 3 ).

Parts of magnetic profiles S-S', G-G', and $\mathrm{I}^{\prime} \mathrm{I}^{\prime}$ are located on the eastern side of Sonoma Valley. These lines each cross the possible east side fault indicated by the gravity data. Profile I-I' (Figure 6), shows anomalies indicating at least one major fault and possibly as many as two others. Profile S-S' (Figure 14) also shows a possible anomaly near the proposed fault, but the magnetic field east of the fault is lower rather than higher unlike profile $\left[-\mathrm{I}^{\prime}\right.$, which suggests a possible reversal in magnetic polarity. Profile G-G' (Figure 3) does not show a clear indication of a fault except for one small positive anomaly located a few hundred feet east of the proposed fault. The geologic map by Fox and others (1973) shows that the eastern end of profile I-I' is over andesite, which is of ten a strongly magnetic rock, but profiles G-G' and S-S' apparently are over rhyolite, which frequently is not a strongly magnetic rock. This may explain why the fault is much more apparent on profile I-I' than it is on the other two profiles. A striking feature of profiles $\mathrm{I}^{-\mathrm{I}^{\prime}}$ and $\mathrm{S}-\mathrm{S}^{\prime}$, however, is the change in character of the magnetic profile from irregular east of the possible fault, to essentially flat, west of the fault. This change in character suggests that west of the possible fault the volcanic rocks are either deeply buried or not present at all.

Profile $Y-Y^{\prime}$ (Figure 19 and Plate 3 ), which trends west of north along State Highway 12 , and profiles $T-T^{\prime}$ and $U-U^{\prime}$ (Figures 15 and 16 and Plate 3 ), which have similar trends but are located west of the proposed "east side" fault, show anomalies that correspond, in part, to gravity anomalies on the same lines. These anomalies tend to corroborate some of the faults or contacts suggested by the gravity data.

\section{Seismic Refraction Surveys}

\section{Purpose}

The seismic refraction method was used in the Sonoma Valley area primarily to determine whether or not the location of the proposed "east side" fault could be confirmed by a different geophysical method. Also, seismic velocities are useful for identifying the types of rock present in the subsurface. Therefore, these data were needed to help interpret the other geophysical data in the area, particularly near the known geothermal resources. 
MAGNETIC PROFILE MA-MA', SONOMA AREA

MA

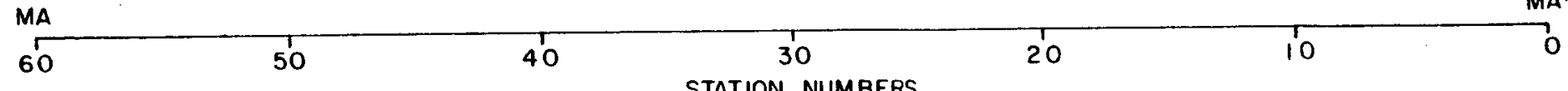

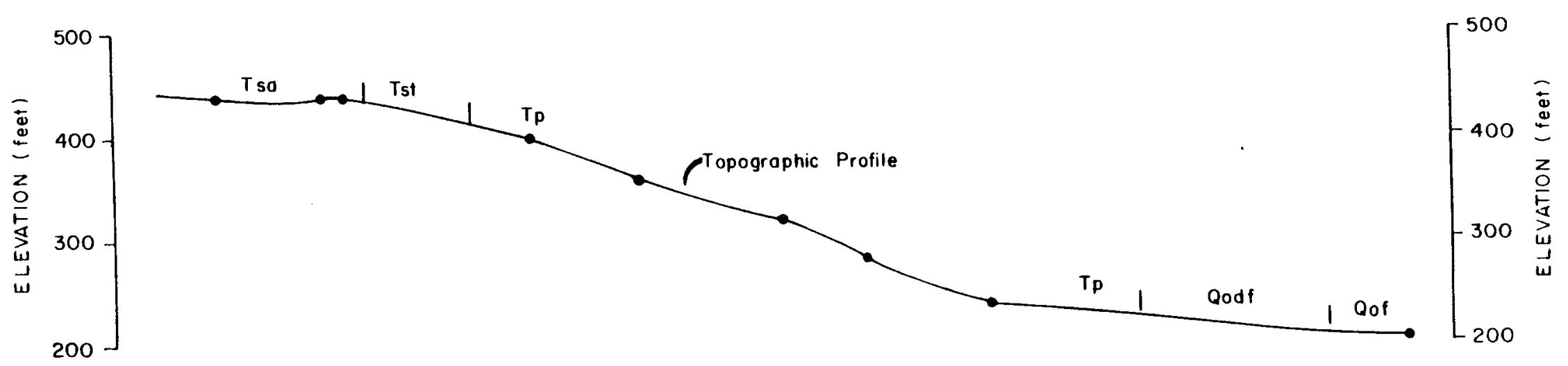

f

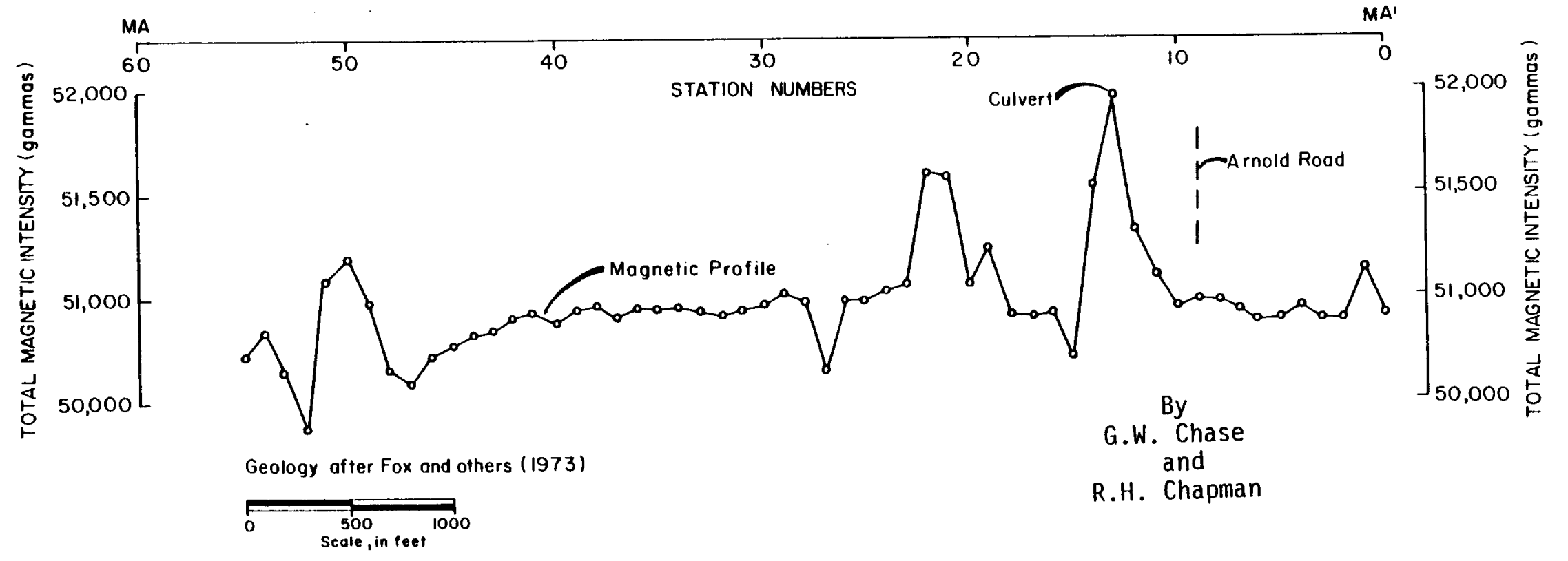

Figure 20. 
MAGNETIC PROFILE MB-MB', SONOMA AREA

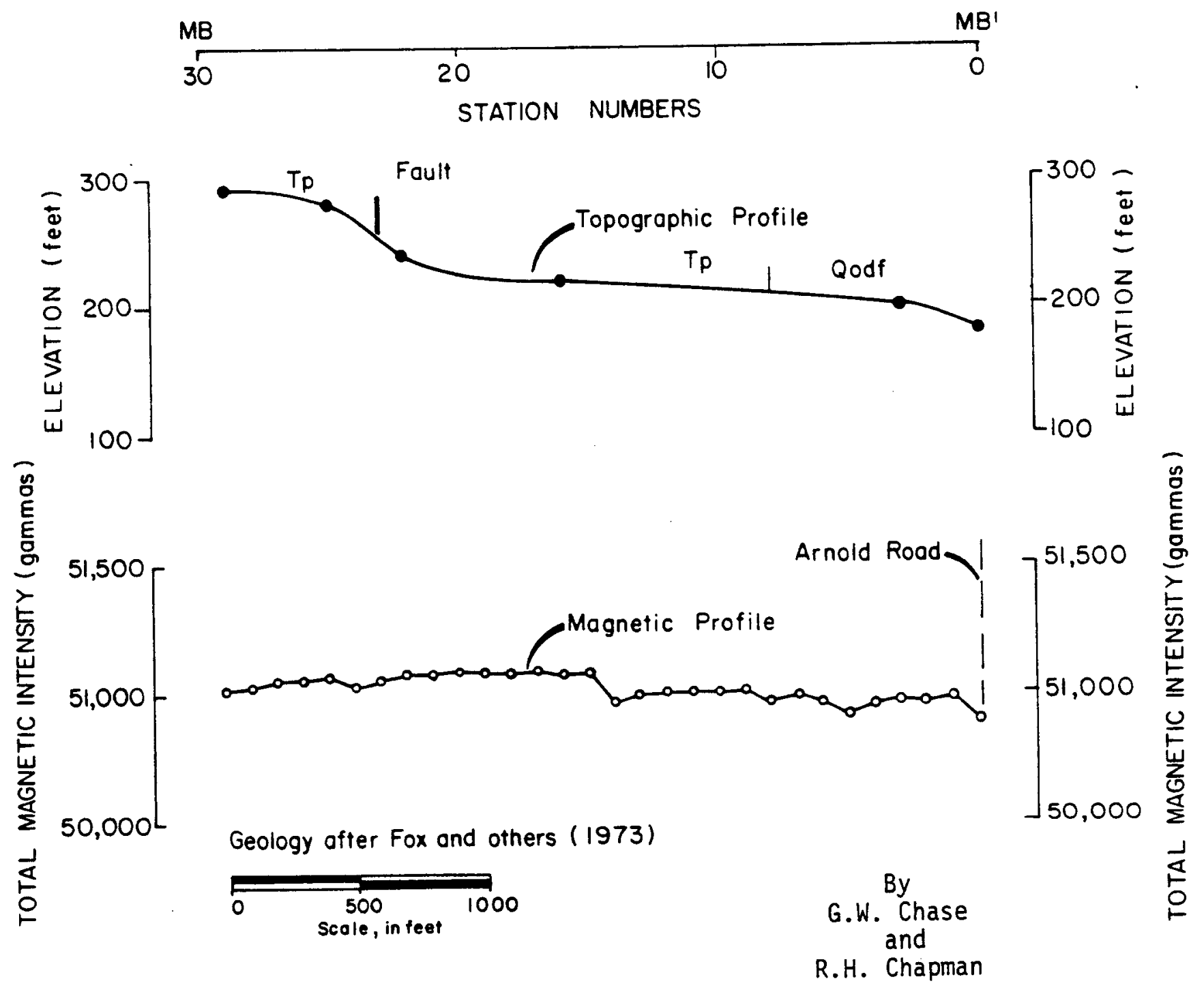

Figure 21. 
MAGNETIC PROFILE MC - MC'

SONOMA AREA
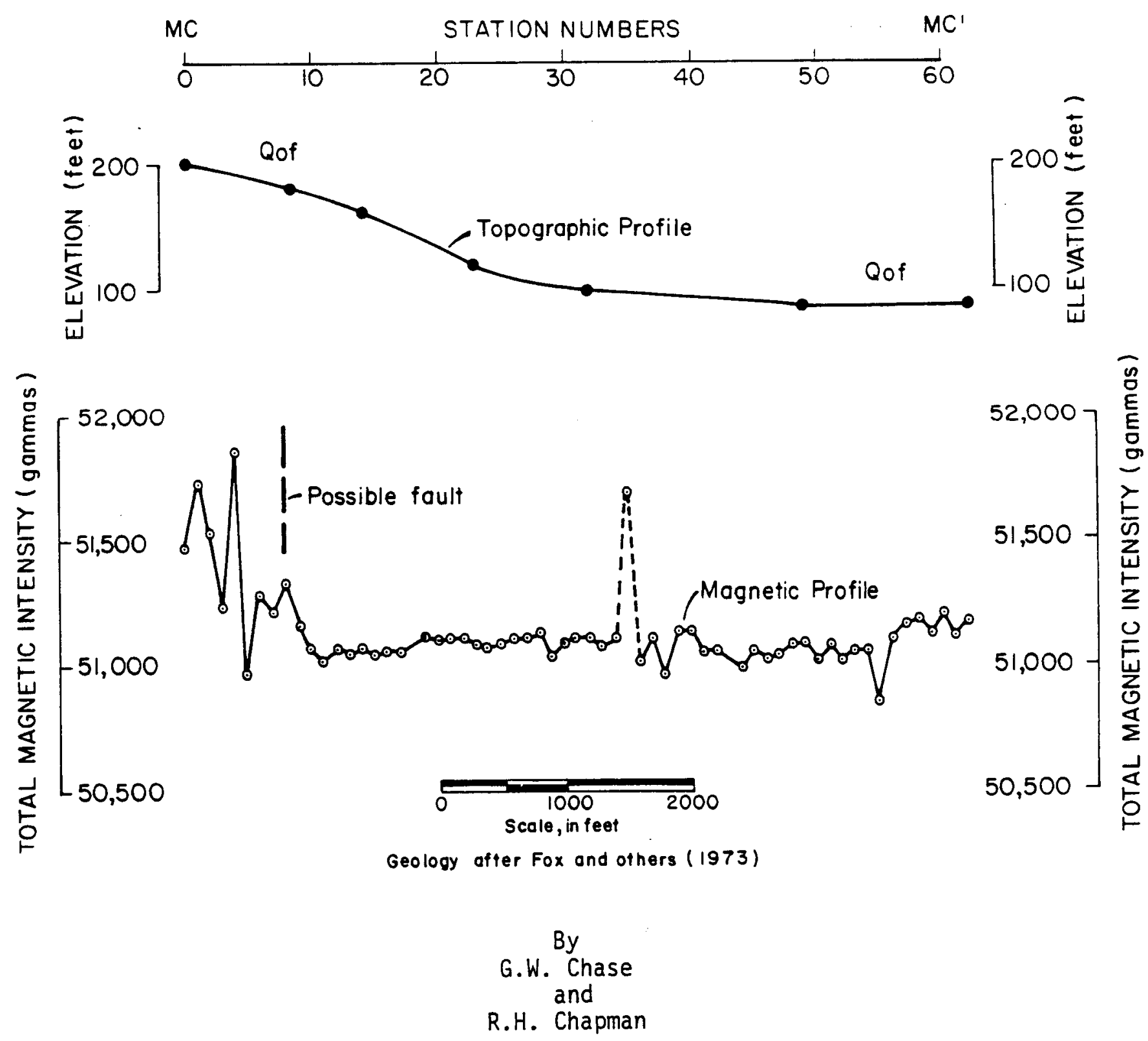

Figure 22. 
Equipment and Field Procedure

Seismic refraction measurements were made in the Sonoma Valley area by means of a Geometrics model ES-1210, 12 channel signal enhancement instrument. The energy source was a $163 \mathrm{kgm}$ ( 360 pound) weight which was allowed to fall about $1.1 \mathrm{~m} \mathrm{(3-1/2}$ feet) to a steel plate on the ground. A geophone cable $168 \mathrm{~m}$ (550 feet) long with $5.2 \mathrm{~m}$ (50-foot) geophone intervals was used. Multiple drops of the weight were necessary to provide sufficient energy to record reliable first arrival data at all geophones. The weight was dropped at each end of the geophone spread to provide a reversed seismic refraction record. After completing measurements at one geophone spread, the cable was moved along $168 \mathrm{~m}$ (550 feet) to provide a continuous line of data.

\section{Seismic Data}

Seismic refraction profiles were run along lines $I-I^{\prime}$ and $V^{\prime}-V^{\prime}$, on the east side of Sonoma Valley, near the location of the proposed "east side" fault (Plate 3). Line V-V' (Figure 17) is located just north of the warm wells at Agua Caliente and Fetters Hot Springs, and line I-I' (Figure 23), is located about one mile to the northwest. Both of these lines have associated gravity profiles, but only line I-I' also has a corresponding magnetic profile and a dipole-dipole resistivity section (Figure 6).

Seismic line I-I' (Figure 23) consists of 5 geophone spreads each $168 \mathrm{~m}$ (550 feet) long. a total length of $838 \mathrm{~m}(2,750 \mathrm{feet})$. The seismic refraction data in the figure indicate a thin, near-surface layer that ranges in seismic velocity from about $244 \mathrm{~m} / \mathrm{sec}$. ( 800 feet per second (fps)) to $366 \mathrm{~m} / \mathrm{sec}$. (1200 fps). Below the surface layer in some places are local layers of limited horizontal extent having seismic velocities of either $610 \mathrm{~m} / \mathrm{sec}$. (2000 fps) or $1067 \mathrm{~m} / \mathrm{sec}$. (3500 fps). The $610 \mathrm{~m} / \mathrm{sec}$. (2000 fps) layer, located at the western end of the line, is about $6.1 \mathrm{~m}$ (20 feet) thick and could represent dry fine-grained flocd plain deposits. The $1067 \mathrm{~m} / \mathrm{sec}$. (3500 fps) layer, located near the central part of the seismic section, has a maximum thickness of about $9.1 \mathrm{~m}$ (30 feet). This layer may consist of dry alluvium or gravel.

On the eastern side of seismic section I-I', east of the "east side" fault, the layer directly below the near-surface layer has a velocity of about $1524 \mathrm{~m} / \mathrm{sec}$. (5000 fps). This layer ranges in thickness from zero to about $21 \mathrm{~m}$ (70 feet), and it may represent water saturated sediments and/or volcanic rocks that probably consist largely of tuffs and breccias. West of the approximate location of the "east side" fault the equivalent layer has a seismic velocity close to $1829 \mathrm{~m} / \mathrm{sec}$. (6000 fps), so it is likely that these two layers consist of somewhat different material.

East of the fault, a layer with a seismic velocity of about $2438 \mathrm{~m} / \mathrm{sec}$. ( $8000 \mathrm{fps}$ ), was found below the $1524 \mathrm{~m} / \mathrm{sec}$. ( $5000 \mathrm{fps}$ ) layer. This is the deepest seismic refractor found, and it may represent relatively dense volcanic rocks, possibly including some flows. This layer was not found west of the "east side" fault, so it is either absent, or it has been offset downward below the depth where it could be detected.

Three areas of possible faulting are shown on seismic section I-I'. The most significant of these probably is the apparent offset of seismic refractors near station 4 (Figure 23). This location is within $23 \mathrm{~m}$ (75 feet) of the location shown for the "east side" fault, which was postulated from gravity data. Possible faults are also shown on the seismic section near station 1 and just west of station 2. Both of these possible faults are located east of the "east side" fault, and both offset the $2438 \mathrm{~m} / \mathrm{sec}$. (8000 fps) refractor. The associated gravity and magnetic profiles (Figure 5) also show anomalies that can be interpreted as faults in these locations. 


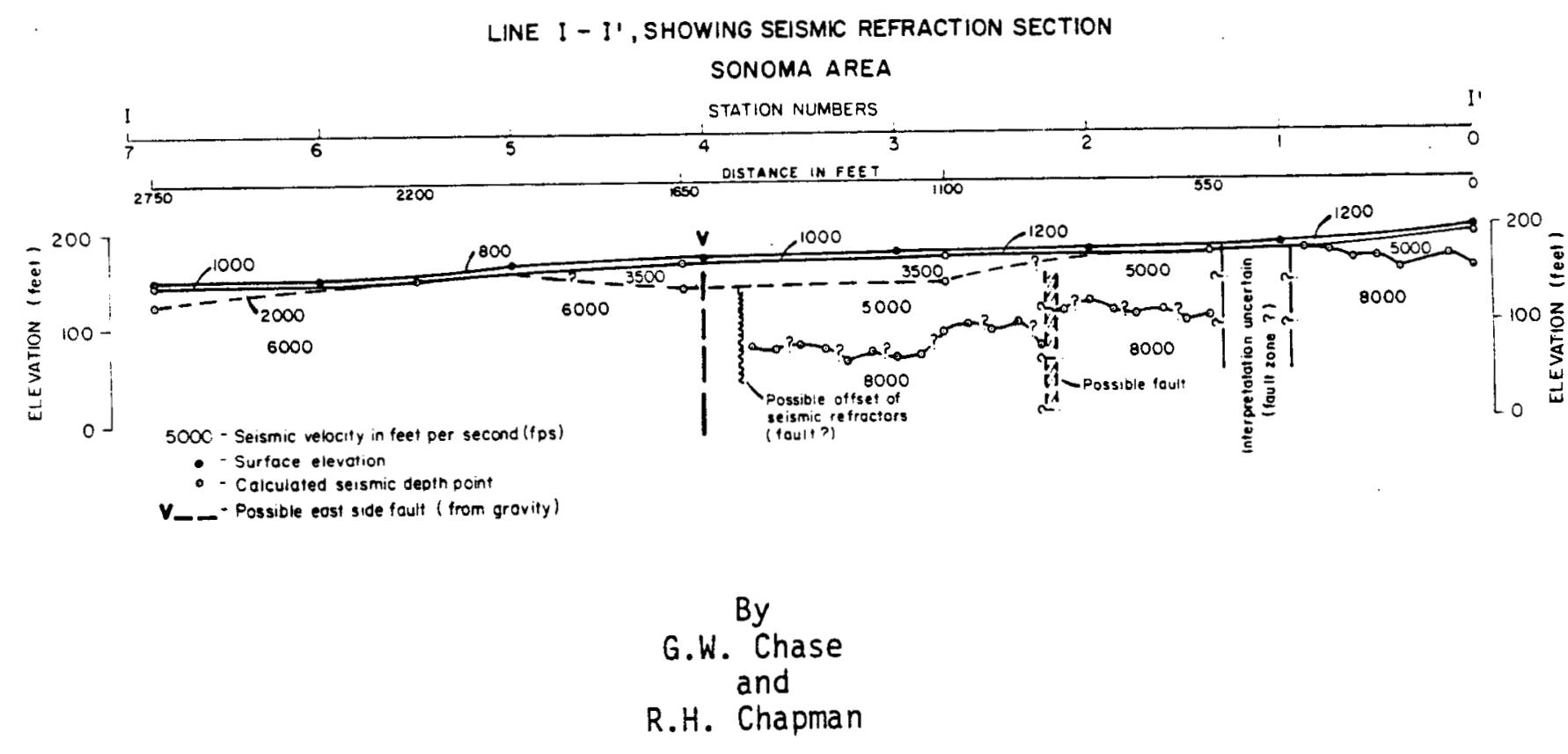

Figure 23. 
Seismic line $V-V^{\prime}$ (Figure 17) is located just north of the warm wells at Agua Caliente and Fetters Hot Springs. This line consists of two $168 \mathrm{~m}$ (550 feet) geophone spreads, a total length of $335 \mathrm{~m}$ (1,100 feet). The seismic data shown in Figure 17 indicate three layers including a thin, near-surface layer with a velocity of about $366 \mathrm{~m} / \mathrm{sec}$. (1200 fps), and underlying layers having seismic velocities of $1676 \mathrm{~m} / \mathrm{sec}$. $(5500 \mathrm{fps})$ and $2438 \mathrm{~m} / \mathrm{sec}$. (8000fps), respectively. These layers are similar to the principal seismic layers found on line $\mathrm{I}-\mathrm{I}$ '. No layers having seismic velocities intermediate between $366 \mathrm{~m} / \mathrm{sec}$. (1200 fps) and $1676 \mathrm{~m} / \mathrm{sec}$. (550 fps) were found on this line, however.

The seismic section for line $V-V^{\prime}$ (Figure 17) also shows two possible faults: one at station 6 near the west end of the section, and the other just east of station 4 . The fault near station 6 is within $23 \mathrm{~m}$ (75 feet) of the location of the postulated "east side" fault based on gravity data. As on line I-I', the $2438 \mathrm{~m} / \mathrm{sec}$. (8000 fps) refractor was not found in the section west of the possible "east side" fault. Therefore, this seismic layer either is not present, or it has been offset downward below the point where it could be identified by the seismic data.

The possible fault located just east by Station 4 on line $V-V^{\prime}$ apparently offsets the $2438 \mathrm{~m} / \mathrm{sec}(8000 \mathrm{fps}$ ) seismic refractor about $18 \mathrm{~m}$ (60 feet) downward to the west. Also, there is no $1676 \mathrm{~m} / \mathrm{sec}$ ( $5500 \mathrm{fps}$ ) layer in the section east of this fault. The gravity profile on line $V-V^{\prime}$ (Figure 17) shows anomalies that also can be interpreted as faults in the same areas as those indicated by the seismic data.

\section{Electrical Resistivity Surveys}

\section{Purpose}

The presence of hot geothermal waters and possible related rock alteration products frequently cause geothermal reservoirs to be characterized by low values of electrical resistivity. The known geothermal resource in the Sonoma area, however, may not have a temperature high enough to cause a distinct resistivity anomaly. Nevertheless, electrical resistivity data might be of help in delineating possible reservoirs in the Sonoma area either by locating the volcanic rocks that may be the reservoirs, or by locating possible alteration zones that may be associated with the reservoirs. Unfortunately, much of the area near the known geothermal resources at Boyes Hot Springs, Agua Caliente, and Fetters Hot Springs is highly developed. As a result, use of the electrical resistivity equipment close to those areas was limited.

\section{Equipment and Field Procedure}

The equipment used for the electrical resistivity survey consists of a Geotronics model FT-4 transmitter with an output rated at 4 amps and 800 volts $(3.2 \mathrm{KVA})$. The power supply, also furnished by Geotronics, is a model B-2 engine generator with an output of $5 \mathrm{KVA}$ at $400 \mathrm{~Hz}$. A Bison signal enhancement receiver was also used.

The resistivity survey in the Sonoma area consisted of two dipole-dipole resistivity lines and three Schlumberger soundings... In the sounding technique, an electrode configuration is expanded about a central point in order to measure progressively deeper values of electrical resistivity.. The results are plotted as a curve showing resistivity as a function of electrode spacing $(A B / 2)$ or depth. In the dipole-dipole survey, the dipole interval used was $61 \mathrm{~m}$ (200 feet), and the receiver was usually moved out from a transmitter dipole-receiver dipole distance $(N)$ of $N=1(61 \mathrm{~m} / 200$ feet $)$ to $N=7$. The transmitter dipole consisted of one or two electrodes at each end, which were thoroughly wet with salt water. After completion of one series of measurements along the line from 
$\mathrm{N}=1$ to $N=7$, the transmitter usually was moved along the line $183 \mathrm{~m}$ (600 feet) and a new series begun. The dipole-dipole resistivity values were plotted in the form of a pseudosection for interpretation. All resistivity measurements were made at a frequency of one $\mathrm{Hz}$.

\section{Interpretation of Resistivity Data}

Dipole-dipole profiles. Dipole-dipole resistivity profiles were run along two of the gravity and magnetic profiles, S-S' and I-I' (Plate 4). Both of these profiles cross the trace of the "east-side" fault suggested by other geophysical techniques. The resistivity pseudosections for profiles S-S' and $\mathrm{I}^{-\mathrm{I}^{\prime}}$ are shown in Figures 14 and 6 , respectively. Resistivity values on the pseudosections are contoured at an interval of $10 \mathrm{ohm}$-feet.

Dipole-dipole line I-I' (Figure 6) has a total length of $1097 \mathrm{~m}$ (3,600 feet). The pseudosection shows relatively high values of resistivity (approximately $100 \mathrm{ohm}-\mathrm{feet}$ ) on the eastern end, but most of the rest of the section is characterized by relatively low values. The high values of resistivity probably are caused by andesite (Sonoma Volcanics) that crops out near the eastern end of the line. The change in resistivity values in this area may correspond to a possible fault shown on the seismic section (Figure 23). Between the location of the possible "east side" fault (near station 18) and the high resistivity values at the eastern end of the line, the resistivity values average about 40 ohm-feet. West of station 18, however, resistivity values average about 30 ohm-feet. Thus, there is a small, but distinct, change in resistivity values near the proposed "east side" fault. The slightly higher values to the east of the "east side" fault may indicate the presence of volcanic rocks in the section, but these rocks must be either weathered, hyarothermally altered, or very porous to yield this low value for resistivity. There is no apparent increase of resistivity with depth in the pseudosection as might be expected if the low values of resistivity are related to weathering, so it is likely that the volcanic units consist, in large part, of somewhat altered water-bearing tuffs and breccias. The somewhat lower values of resistivity to the west may indicate sediments, perhaps containing a significant amount of clay. The fact that the contours of resistivity on the pseudosection (Figure 6) tend to parallel the lines of values taken at each transmitter location may indicate some minor interference from local, near-surface changes in resistivity.

Dipole-dipole line S-S' (Figure 14) has a total length of $975 \mathrm{~m}(3,200 \mathrm{feet})$. The values of apparent resistivity on this pseudosection are within a relatively small range (19-45 ohm-feet). The contours of apparent resistivity in Figure 14 clearly tend to follow the lines of resistivity data taken at each transmitter location. As mentioned in the discussion of pseudosection I-I', this characteristic probably means that there are local, near-surface changes in resistivity. The pseudosection for line S-S' (Figure 14) shows no clear demarcation between resistivity values on either side of the proposed fault. Evidently, there is little contrast in electrical resistivity between the volcanic units believed to be present at depth on the eastern part of this line, and a thick section of alluvium and sediments on the western part.

Neither of the two dipole-dipole lines show the extremely low resistivity values that might be associated with a high-temperature geothermal reservoir. The observed values are likely to represent either sediments containing a high proportion of clay or altered water-bearing volcanic units. 
Vertical Electrical Soundings (VES). The locations of the three Schlumberger soundings are shown on Plate 4. The current electrode spacings for these soundings were expanded to a total distance $(A B)$ of from 488 to $732 \mathrm{~m}(1,600$ to 2,400 feet). The resulting sounding curves (Figures 24-26) were first approximately interpreted by means of the master curves by Orellana and Mooney (1966) and Rijkswaterstaat (1969). The thickness and resistivity values obtained by this method were then used to calculate theoretical sounding curves by means of a hand calculator program (Haines and Campbell, 1980). The final interpreted values of thickness and resistivity shown in the figures are the result of changing some of the parameters to produce a better fit with the observed data.

The center of VES 1 is located about $762 \mathrm{~m}$ (2,500 feet) northwest of the warm wells at Agua Caliente and Fetters Hot Springs (Plate 4). This location is about $152 \mathrm{~m}$ (500 feet) west of the fault indicated by the gravity data in this area. The electrode configuration was expanded along a northwest-trending gravel road that is subparallel to the estimated fault trend. The maximum electrode spacing (AB) was $732 \mathrm{~m}(2,400 \mathrm{feet})$. The interpretation of this sounding curve (Figure 24) shows a layer with a thickness of over $213 \mathrm{~m}$ (700 feet), most of which has a relatively low value of resistivity (35-42 ohm-feet), that overlies a layer with a relatively high resistivity (approximately 750 ohm-feet). Two shallow, thin layers with resistivity values of $170-175$ ohm-feet are also identified between the surface and a depth of about $1.3 \mathrm{~m}$ ( $4 \mathrm{feet}$ ) and between depths of 3.7 and $8.5 \mathrm{~m}$ ( 12 and $28 \mathrm{feet}$ ), respectively. The shallow layers with the higher resistivity might represent water-saturated gravels, and the layers with a lower resistivity might represent sediments with a high proportion of clay. The layer with a high resistivity at a depth of about $213 \mathrm{~m}$ (700 feet) might be unaltered volcanic rocks or possibly Franciscan rocks.

The center of VES 2 is located along Highway 12 , about $366 \mathrm{~m}(1,200$ feet $)$ nor thwest of the eastern end of line I-I', on the east side of Sonoma Valley (Plate 4). The maximum electrode spacing (AB) for this sounding was $610 \mathrm{~m}(2,000$ feet). The interpretation of this sounding (Figure 25) indicates a surface layer with a resistivity of about 65 ohm-feet. Below this layer to a total depth of at least 46 to $61 \mathrm{~m}$ (150 to $200 \mathrm{feet}$ ) is a layer with a relatively low resistivity of about 36 ohm-feet. This may represent alluvium containing clay and/or partially altered volcanic rocks. At a distance $A B / 2=91 \mathrm{~m}$ (300 feet) on the sounding curve, there is a sharp increase in apparent resistivity that cannot be explained by horizontal layering in the subsurface. This anomaly probably is caused by an exposure of andesite (Sonoma Volcanics) located at a distance $(\mathrm{AB} / 2)$ of about $305 \mathrm{~m}(1,000 \mathrm{feet})$ on the south end of the profile.

VES 3 (Plate 4) is centered on the west side of Sonoma Valley along a nor theast-trending road west of Arnold Drive, a distance of about $457 \mathrm{~m}$ ( 1,500 feet) nor th of Hanna Boys Center. The maximum electrode spacing $(A B)$ on this sounding was $488 \mathrm{~m}$ $(1,600$ feet). The sounding curve (Figure 26) is relatively featureless out to a distance $(\mathrm{AB} / 2)$ of about $91 \mathrm{~m} \mathrm{(300} \mathrm{feet)} \mathrm{where} \mathrm{there} \mathrm{is} \mathrm{a} \mathrm{sharp} \mathrm{rise} \mathrm{in} \mathrm{apparent} \mathrm{resistivity.} \mathrm{This}$ anomaly cannot be explained by horizontal layering, so it probably is caused by electrically resistive rocks near the surface at the west end of the electrode configuration. The interpretation of the sounding curve (Figure 26) down to a depth of about $91 \mathrm{~m}$ ( $300 \mathrm{feet})$ indicates thin, near-surface layers with resistivities of $35 \mathrm{ohm}-$ feet and 45 ohm-feet, respectively, underlain by a thick layer with a resistivity of about $28 \mathrm{ohm}$-feet. These resistivity values indicate sediments containing clay. The shallow layers with slightly higher values of resitivity may contain more gravel than the deeper layer. 


\section{SCHLUMBERGER SOUNDING | AND INTERPRETATION}

SONOMA AREA

$1000-$

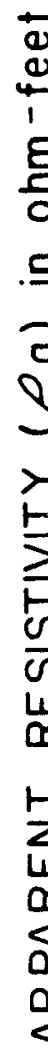

$\Delta \Delta \Delta \Delta$

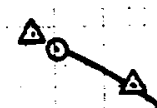

$\frac{1}{0}$

$\subseteq$

Q

$\frac{\pi}{2}$

$\widetilde{x}$

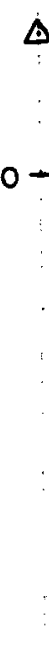

$10-\ldots+-\mathrm{BH}_{\mathrm{By}}+\mathrm{Chase}$

Q OBSERVED DATA

By
B.W. Chase
and
a
a R.H. Chapman

$\triangle$ CALCULATED DATA

WTERPRETED

TRUE RESISTIVITY IN OHM-FEET AND OEPTH IN FEET

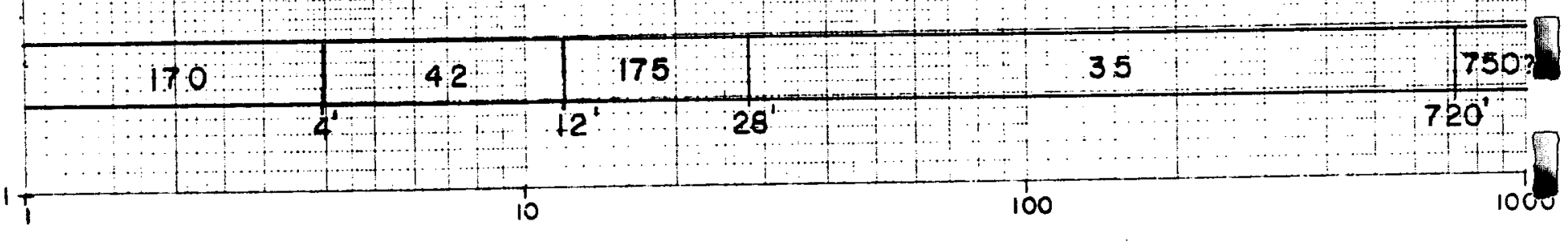

ELECTRODE SPACING (AB/2) IN FEET

Figure 24. 


\section{SCHLUMBERGER SOUNDING 2 AND INTERPRETATION}

\section{SONOMA AREA}

$1000-$

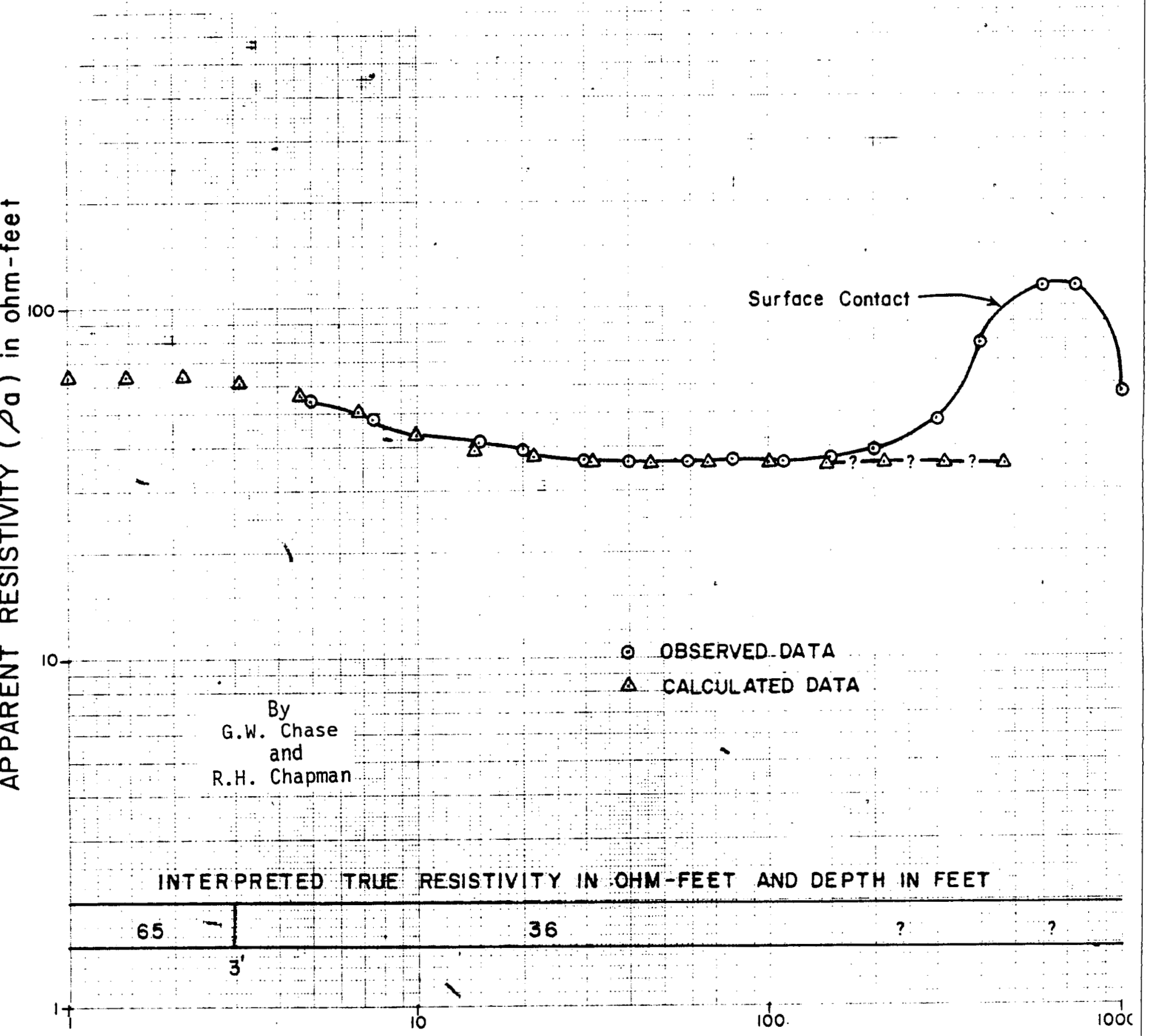

ELECTRODE SPACING (AB/2) IN FEET

Figure 25. 
SCHLUMBERGER SOUNDING 3 AND INTERPRETATION SONOMA AREA

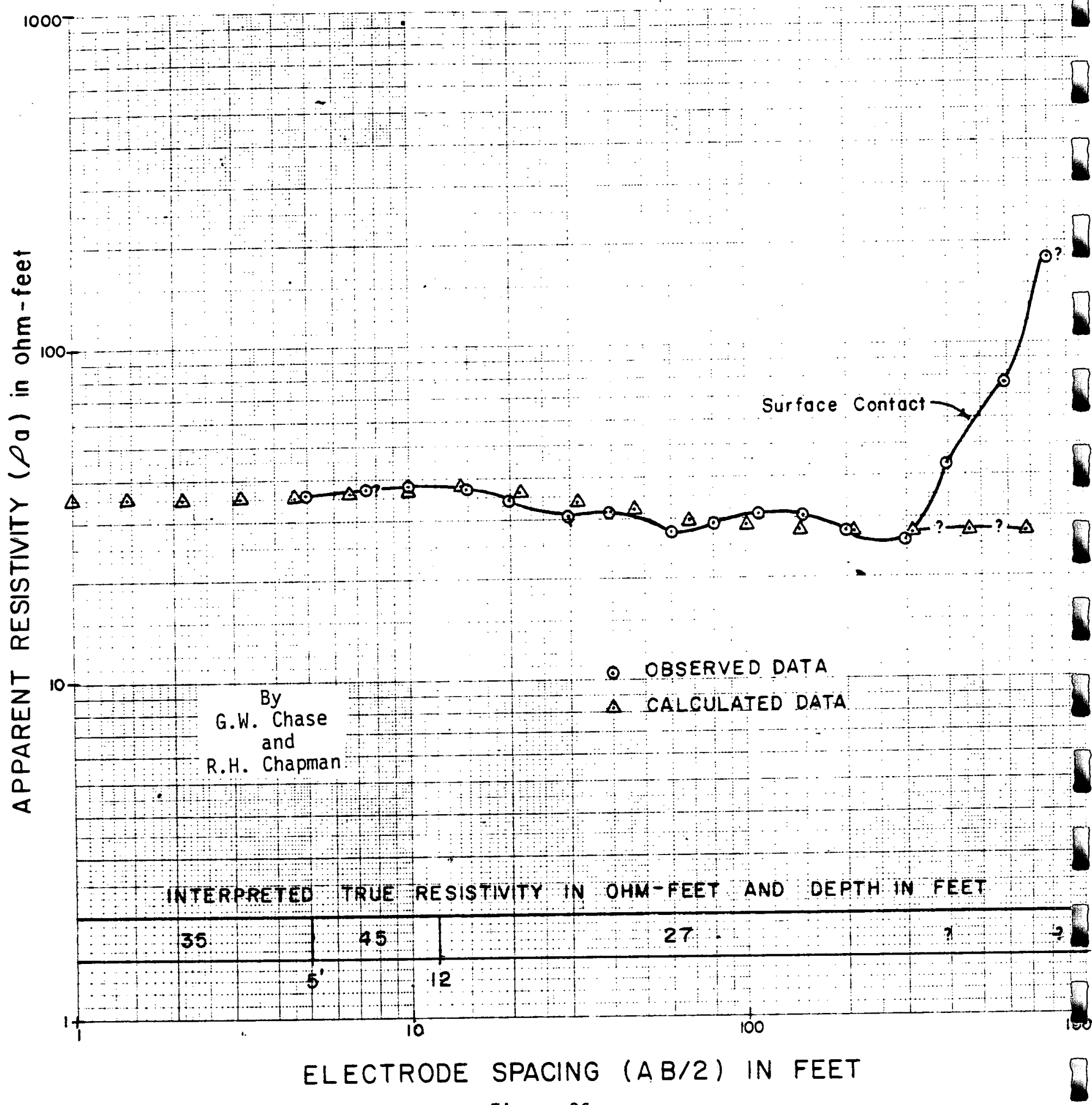

Figure 26. 
All three resistivity soundings, as well as the two dipole-dipole resistivity lines, appear to indicate generally low values of resistivity regardless of where in the valley the measurements were taken. These low values of electrical resistivity probably indicate the presence of clay-bearing sediments or altered volcanic rocks. There apparently are no resistivity anomalies related to the geothermal resources, at least in the areas tested, and, generally, it is not even possible to distinguish between sediments and volcanic rocks in the valley.

\section{Conclusions and Recommendations}

Geophysical studies in the Sonoma Valley area have provided information that is useful in the search for additional geothermal resources. This information includes the identification of some possible faults, some of which appear to be related to the geothermal resources, and the location of dense and magnetic units of the Sonoma Volcanics that in some cases apparently contain geothermal aquifers.

Possible faults in the Sonoma Valley area were located by means of gravity, ground magnetic, and seismic refraction data. One of these possible faults, the "east side" fault, is closely associated with the historically known geothermal resources on the northeast side of Sonoma Valley. Magnetic and gravity data were also found to be of value for locating buried volcanic rocks that might serve as reservoirs for geothermal fluids in the area. A knowledge of the location of both the buried volcanic rocks and the faults in the area is important particularly when these are found to be associated with geothermal resources.

Electrical resistivity data apparently did not prove to be very useful, in general, for identification of either geothermal reservoirs or geologic structure in the area tested. However, the resistivity data do show one possible near-surface fault also shown by seismic refraction data. It is possible that sediments containing clay and either weathered or hydrothermally altered volcanic rocks have similar resistivities in this area.

The known geothermal resources in the Sonoma Valley area are found in wells that are believed to be, for the most part at least, in units of the Sonoma Volcanics. A majority of these warm wells are located in the upthrown block east of the fault on the northeast side of Sonoma Valley (Plate 1). This fault may act as a barrier to ground-water movement, and/or it may provide a pathway to the surface for the warm water. Thus, the most favorable locations to find additional geothermal resources in the Sonoma Valley area appear to be in the volcanic rocks both on the northeast side of the "east side" fault. and where these rocks may be present at greater depth in the valley. Gravity and aeromagnetic data indicate possible volcanic rocks in the valley near Sonoma State Hospital and Glen Ellen and in an area southwest of the City of Sonoma.

Sufficient geophysical work has been done to define the approximate location of the postulated "east side" fault from the vicinity of the City of Sonoma, on the south, to the vicinity of Glen Ellen on the north. It is recommended that additional magnetic and gravity data be obtained near Sonoma State Hospital. Glen Ellen, and southwest of the City of Sonoma to provide more detailed information on both the "east side" fault and the buried volcanic rocks in these areas that might be future sources of geothermal fluids. 
8

.

8

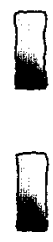

$\nabla$

$\sqrt{2}$

$\mathbb{E}$

$B$

$D$

$\sqrt{3}$

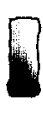

$\sqrt{2}$

$\square$

.

8

$\triangle$

8 


\section{REGIONAL SEISMICITY OF THE SONOMA VALLEY}

\section{Introduction}

It is widely recognized that seismic activity is often high in and around the major geothermal areas of the world and that, in some geothermal areas, there is a direct correlation between seismic activity and fluid withdrawal. The monitoring of seismic noise associated with geothermal areas has also been used as a tool for geothermal resource exploration.

\section{Methodology}

To evaluate the regional pattern of seismic activity around the Sonoma Valley area and to ascertain if the seismic activity bore any relationship to the low-termperature geothermal resources, all seismic events from 1800-1974 were computer plotted and then manually transferred to a base map of the study area (Plate 6). Seismic data used for computer plotting were obtained from the California Division of Mines and Geology (CDMG) Earthquake Catalog System (Real and others, 1978).

\section{Results}

Forty-four events have been recorded for the Sonoma Valley study area. Thirty-eight events were computer plotted. The system does not allow "over-prints". Therefore, only one of several events (the largest) occurring at the same coordinates, but at different times, is plotted.

Table 1 is a reproduction of the computer listing of all the earthquakes pertinent to study. The table provides earthquake data on location, time, depth, magnitude, etc. A magnitude (MAG) of 9.99 means that no data were available to determine the actual magnitude of the event.

The CDMG Earthquake Catalog has been compiled from a great many sources of information. Data for the earthquakes recorded in Table 1 have been compiled from the sources listed below:

\section{REFERENCES}

\section{Number}

1 University of California, Berkeley (1976). Magnetic tape catalog of earthquakes in nor thern California, 1910-1974.

7 Toppozada, T.R., Parke, D.L., and Higgins, C.T., 1978, Seismicity of California, 1900-1931: California Division of Mines and Geology Special Report 135, 39 p.

8 Toppozada, T.R., Real; C.R., and Parke, D.L., 1981, Preparation of isoseismal maps and summaries of reported effects for pre-1900 California earthquakes: California Division of Mines and Geology Open-File Report 81-11 SAC, Annual Technical Report to the U.S. Geological Survey, Grant No. 14-08-001-19200, $182 \mathrm{p}$.

9 U.S. Geological Survey (1976). Magnetic tape catalog of earthquakes in west-central California, 1969-1973.

Prior to about 1969, earthquake events in northern California were recorded primarily by the U.C. Berkeley seismograph network. Then the U.S. Geological Survey 
Table 1. Tabulated data of the earthquakes that have occurred within the Sonoma Valley study area $(1800-1974)$.

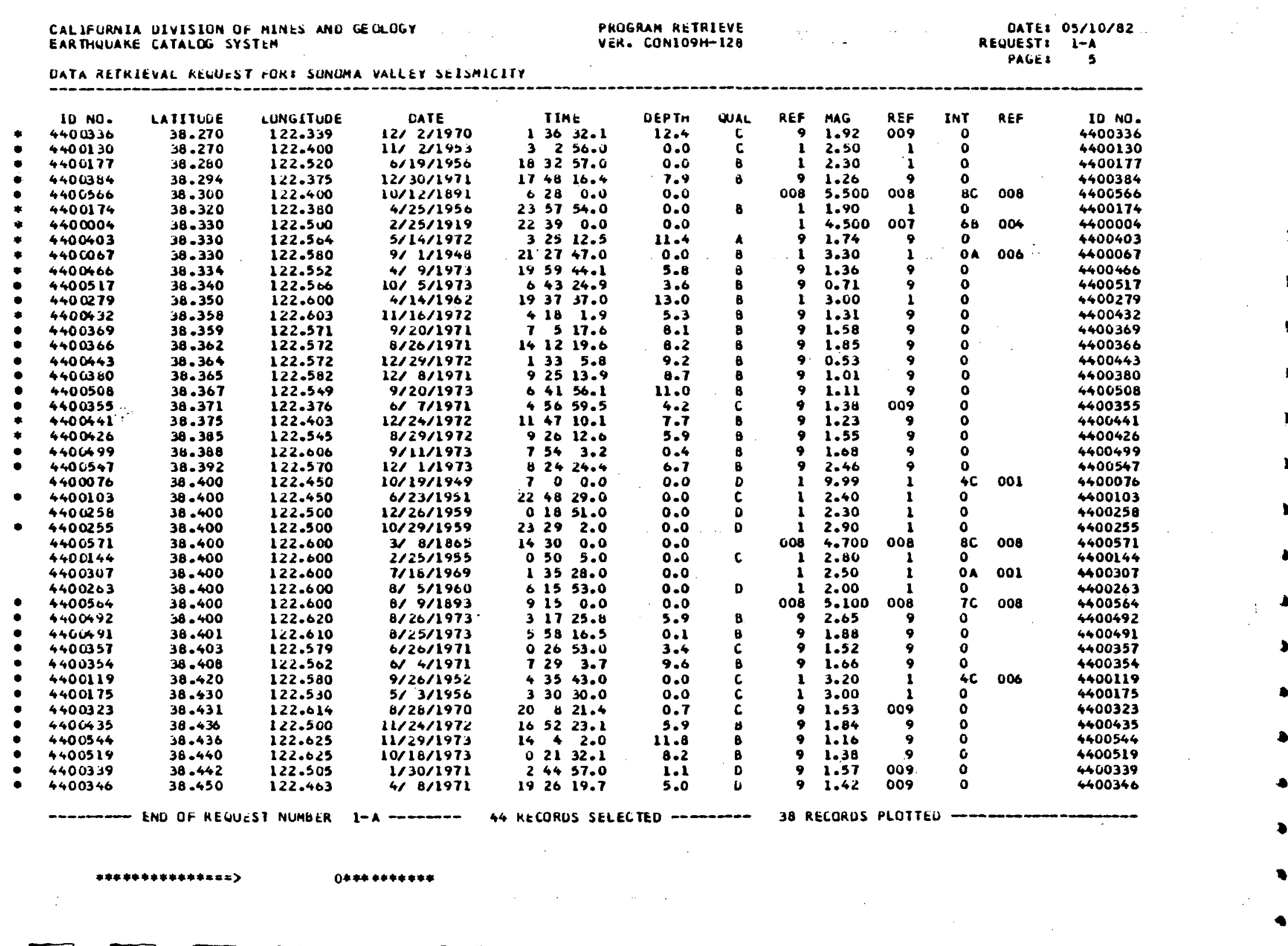


sited several instruments in northern California counties. The higher seismograph station density provides better quality data. Hence, epicenter locations recorded post-1969 by the U.S. Geological Survey are of higher quality than events reported earlier.

The quality (QUAL) ratings listed in the table are somewhat arbitrary and are not directly comparable from one source to another. The following key provides the criteria the institutions above use to assign quality judgments. Also, the codes accompanying the magnitude and intensity (INT) values are explained.

\section{KEY TO RECORD PARAMETER CODES}

I. Quality of Hypocenter (QUAL)

A. Source: U.C. Berkeley (REF 001)

Epicenter quality is subjective, ranging in quality from high to low as follows:
A. - Excellent
B. - Good
C. - Fair
D. - Poor

B. Source: U.S. Geological Survey (REF 009)

$\begin{array}{cc}\text { Epicenter } & \text { Focal Depth } \\ 1 \mathrm{~km} & 2 \mathrm{~km} \\ 2.5 & 5 \\ 5 & 5 \\ 5 & 5\end{array}$

II. Type of Magnitude (MAG)
A - Local Richter
B - Surface wave
C - Body wave
D - Local estimated for intensity
E - Local estimated from duration

III. Type of Intensity (INT)
A - No intensity given but felt
B - Rossi-Forel
C - Modified Mercalli

The epicenter locations were manually transferred to the Sonoma Valley area topographic base map (Plate 6). The majority of the epicenters are in the northwest portion of the map in the Sonoma Mountains.

The Sonoma Valley proper is particularly devoid of epicenter locations except for one earthquake of magnitude 4.5 on February 2, 1919, approximately located at latitude 38.330, longitude 122.500 on Plate 6 (Table 1). This epicenter location is on or very near the "east side" fault described elsewhere in this report.

Historically, earthquake activity may have affected the character of both hot and cold springs in the area to some extent. The following accounts from historic literature seem to confirm this conclusion: 
1. Toppozada, T.R., and others, 1980:

Earthquake of Uctober 12, 1891, M=5.5, 6:28 GMT, latitude 38.330, longitude 122.400, located approximately near the Sonoma-Napa County border (Plate 6):

The Sonoma Democrat (Santa Rosa), October 17, 1891, p. 5.

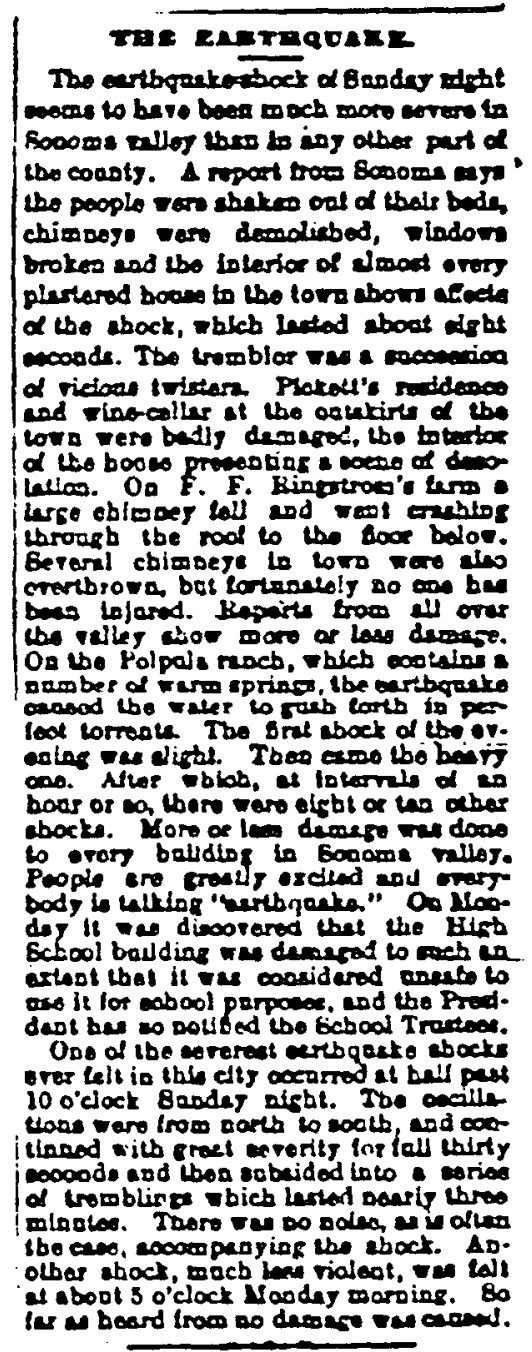

Sentence eight of the first paragraph proclaims a vast increase in hot water flow from warm springs in the area. 
2. Toppozada, T.R., and others, 1980:

Earthquake of March 31, 1898. Intensity $=7$ in Glen Ellen area 7:43 GMT latitude 38.200 , longitude 122.400 , located in the San Pablo Bay area just south of the map area of Plate 6:

The Santa Rosa Press - Democrat (Santa Rosa), April 6, 1898, p. 1.

\section{SPRIMGS FLOIF FREELY . AFTER TBE EIRTEQUAKE}

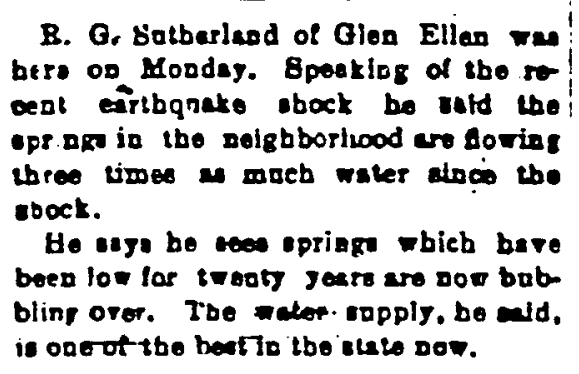

3. Waring, G.A., 1915:

"On the. .. farm of the State Hoine at Eldridge (Sonoma State Hospital) water $72^{\circ}(\mathrm{F}$ ) in temperature is obtained from a spring that ... broke forth at ... the time of the earthquake of April 18, 1906, and a flowing well 50 yards northward ceased to flow."

4. Waring, G.A., 1915:

"The wells (at Boyes Hot Springs), the first of which was drilled about 1890, flowed until a short time after the earthquake of April 18, 1906..."

\section{Conclusions}

Investigation of epicenter locations provides little insight into the low-temperature geothermal resources of the Sonoma Valley area. There is little obvious pattern or relationship of earthquakes from 1800-1974 to the regional or local structural fabric. However, if historic accounts are correct, large earthquakes in or near the Sonoma Valley can change the flow characteristics of warm springs and possibly warm water wells also. 



\section{GEOCHEMISTRY}

\section{Introduction}

Geochemical analyses of fluids from a geothermal reservoir provide a means for determining many diagnostic properties of that reservoir. The chemcial composition of thermal waters can be used to quantitatively estimate reservoir temperature by using geothermometry algorithms. Analyses of mineral segregation in thermal fluids may indicate lateral and/or vertical structural features or barriers within or bounding a geothermal reservoir. Geochemistry analyses of thermal fluids may also be able to provide some clues to the type of thermal system being investigated including such parameters as heat source, path of fluids, etc.

Early chemical data are recorded for some geothermal springs and wells in the Sonoma Valley by Crawford (1894), Waring (1915), Kunkel and Upson (1960), Berkstresser (1968), Ford (1975), Leivas and others (1981), and most recently Herbst (1982) among others.

\section{Methodology}

The CDMG had planned to sample as many geothermal wells or springs and fresh water wells as possible to aid in the geothermal resource investigation of the Sonoma Valley area. A total of 41 samples were collected in the field time allowed. The locations are designated $\mathrm{C}-1$ through $\mathrm{C}-41$ on Plate 7 . The geochemical analyses of these sites are presented in Table 2.

Approximately one gallon of fluid was obtained at each well or spring. The discharging water temperature was recorded also. The sample was filtered and divided into portions for shipment to the University of Utah Research Institute (U.U.R.I.) and to the Geochemical Laboratory of the CDMG at San Francisco and for on-site field anlysis.

The cation analyses in Table 2 were performed at U.U.R.I. on an Inductively Coupled Plasma Spectrometer. Also, U.U.R.I. analyzed for two anions; chloride (Cl) and fluoride (F). The remaining chemcial properties presented in Table 2 for each sample were determined by CDMG either in the field utilizing their portable geochemistry laboratory facilities or in the CDMG Geochemical Laboratory at San Francisco.

Concentration ratios for some constituents in the 41 samples were calculated and are presented in Table 3. A diagnostic water type designator was assigned to each sample after a subsequent review of the data. The designators are listed under "Chemical Characteristics" in Table 2. The areal distribution of the various water types is shown on Plate 7.

\section{Results}

Some chemical similarities and differences in the 41 sampled waters from the Sonoma Valley area are evident in Table 2. Some of those observations are listed below:

- Three of the four water samples with boron (B) levels greater than $2 \mathrm{mg} / \mathrm{l}$ are from wells along the fault on the east side of Sonoma Valley. These wells are Locations No. C-33, C-40, and C-41. The exception is Location No. C-4 on Plate 7.

- A northwest-trending line ("diamond" line on Plate 7) can be drawn subparallel and west of the long fault on the east of Sonoma Valley. West of this line only 
Table 2. Geochemical analyses of 41 wells and springs sampled in the Sonoma Valley area. By H.H. Majmundar, 1982, CDMG.

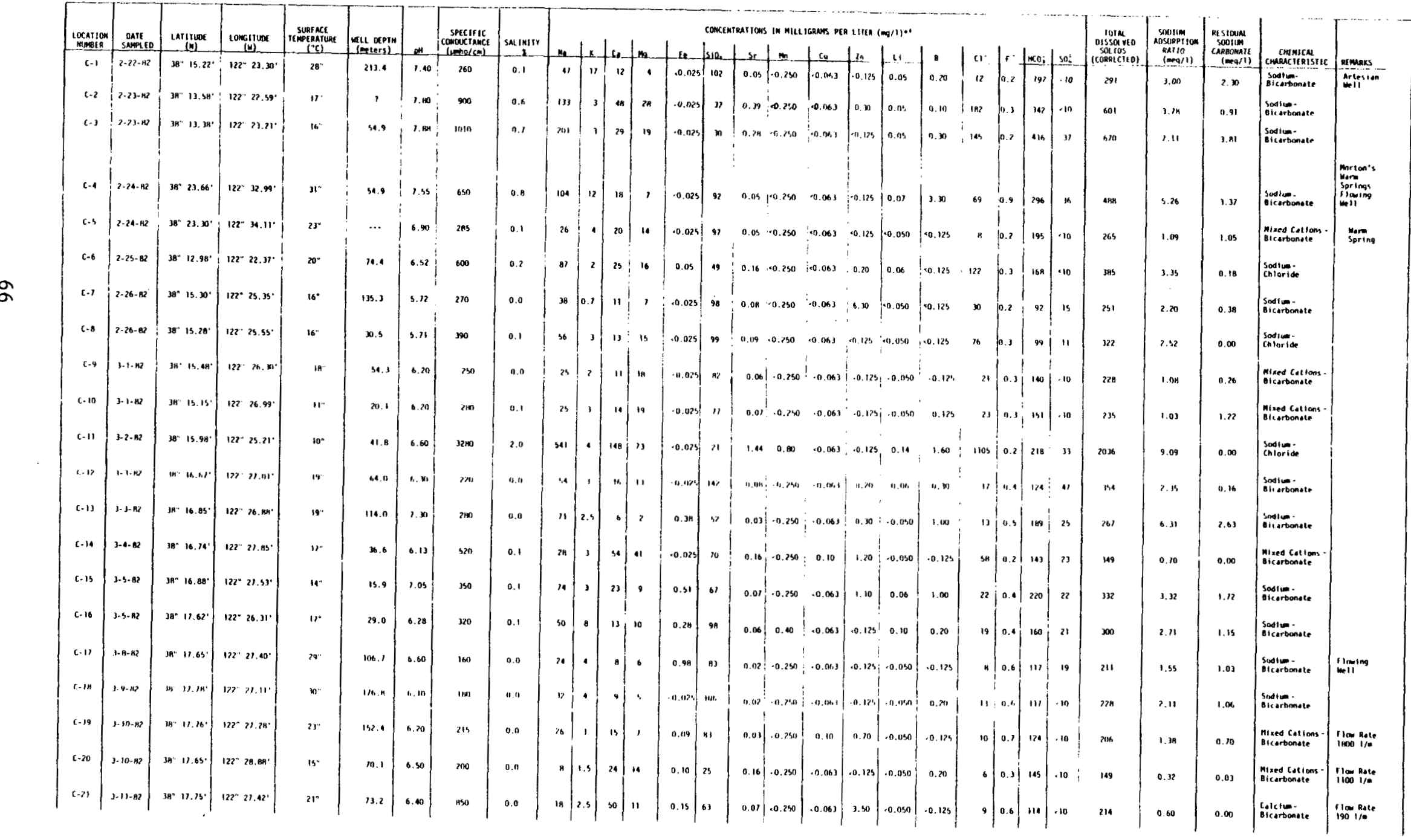




\begin{tabular}{|c|c|c|c|c|c|c|c|c|c|c|c|c|c|c|c|c|c|c|c|c|c|c|c|c|c|c|c|c|c|}
\hline$c-22$ & $3-11-82$ & $3 \mathrm{~F}^{\circ}+17.90^{\circ}$ & $12 z^{-2} 27.0 \mathrm{~N}^{\circ}$ & 28" & 67.1 & 6.20 & 18 & 0.0 & $2 \%$ & & " & - & 0.18 & 93 & 0.02 & 0.256 & -0.063 & $0.28:$ & .0 .050 & .0 .172 & & 0.511 & $105 \mid .10$ & 10 & and & 2.n & 0.99 & 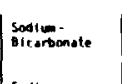 & 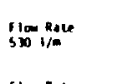 \\
\hline$(.23$ & $3-15-.82$ & $3 H^{\prime}=17.88^{\prime}$ & $122^{\circ} 28.40^{\circ}$ & (1) & 223.6 & 1.78 & 223 & 0.0 & st: & & $\therefore$ & (1). $\sin ^{\prime}$ & $0.21 !$ & 68 & 0.011 .0 & $0.2 \%$ & -61.063 & -0.173 & 1.10 & 0.30 & 3 & 0.6 & \begin{tabular}{l|l}
102 & $\cdot 10$
\end{tabular} & $n$ & 193 & 10.09 & 2.23 & 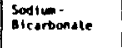 & 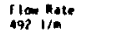 \\
\hline$c-24$ & $3.15-42$ & 16" 17.95 & $122^{\circ} 21.91^{\circ}$ & 24 & 61.0 & 6.62 & 1911) & 0.0 & & & $m+1$ & & -0.028 & $m$ & $0.15 \therefore 0$ & 0.250 & -0.063 & 0.125 & - . $04 n$ & 0.20 & & 0.2 & \begin{tabular}{l|l|l}
121 & .10
\end{tabular} & 10 & 132 & 0.34 & $0 . \infty$ & 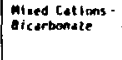 & $\lim _{400} \sum_{1 / \infty}^{\text {nate }}$ \\
\hline 1. $-\mu_{4}$ & $1 \cdot 16-128$ & 3н 18.13 & $12 r=31.94^{\circ}$ & 14 & 76.2 & 9.9 & m & 0.11 & a & & $s^{i}$ & י & 0.5k & $*$ & $0 ., 1,3 \cdot n$ & n. 2806 & -9...4. & (a.1225i. & o. 6.958 & -4.1.25: & $9\}$ & 0.1 & $3 n ! 17$ & & $m$ & 0.07 & 0.17 & 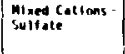 & \\
\hline 1.86 & $1-16-42$ & $38^{\circ} 18.28^{\circ}$ & $122^{2} 28.91^{\circ}$ & $1 \%$ & 27.4 & 6.15 & (4) & 0.2 & 58! & & os 1 & & 0.94 & so & $0.11 n$ & 0.60 & $.0 .061 \mid$ & -0.123 & 0.39 & 1.30 & 56 & 0.1 & 203 & $"$ & 336 & 2.17 & 1.67 & 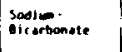 & \\
\hline$(-2)$ & $3-17-82$ & $38^{\prime \prime} 18.25^{\circ}$ & $122=29.91 \%$ & 21 & 52.1 & 6.24 & 260 & 0.0 & 32 & 1.4 & 19 & 8 & 0.10 & 6! & $0.13 \ldots 0$ & 0.250 & 0.063 & $|0.825|$ & -0.056 & 0.125 & 15 & 0.4 & 145 ! & 10 & 280 & 1.55 & 0.76 & 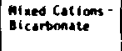 & \\
\hline c-2A & $3-18-82$ & $3 F^{\prime \prime} \quad 17.56^{\circ}$ & 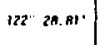 & 18 & 21.3 & 6.90 & 40 & 0.1 & 59 & “ & 22 & 25 & -0.025 & 4 & 0.140 & 0.10 & -0.063 & $\begin{array}{ll}0.20 & \end{array}$ & $-0.050 \mid$ & 0.20 & 18 & 0.3 & 302 & 10 & 351 & 2.00 & $1.2 \mathrm{~B}$ & 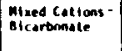 & \\
\hline $6-29$ & ].18-.82 & $38^{\circ} 17.68^{\circ}$ & $122^{\circ}=27.51^{\circ}$ & $21 "$ & 10.1 & 6.80 & 105 & 0.8 & 25 & 5 & . & 5 & 2.69 & 96 & $0.04: 0$ & 0.40 & 0.063 & 0.125 & $-0.050 \mid$ & 0.125 & 9 & 0.6 & 110 & 10 & $2+1$ & $1 . n$ & 1.06 & $\begin{array}{l}\text { sodve- } \\
\text { nicustonate }\end{array}$ & $\begin{array}{l}\text { Artes } \\
\text { Weli } \\
\text { Won }\end{array}$ \\
\hline$\therefore 0$ & 1-199- $-\mathrm{zz}$ & $36=17.62^{2}$ & $122^{2} 29.13^{\prime}$ & r & 25.9 & 6.25 & $m$ & 0.11 & & & 74 & its & 10.37 & nit & a.11. & $.0 .250^{\prime}$ & 0.00 & 1.40 & 0.050 & 0.125 & $2 n$ & 0.2 & 1600. & .10 & 231 & 0.96 & 0.90 & 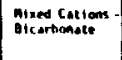 & \\
\hline c." & $n-\pi x-\infty x^{2}$ & in' $20 . \mathrm{m}^{\circ}$ & 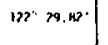 & $n$ & th. 7 & 6.91 & $11:$ & "1.". & $w_{1} 1$ & & 1 & 1 & - in.tine & " & n.min & (1). $7 \times$ & $-n . n_{0}, 3$ & -0.124 & $0.0 \%$ & (1). & sii & 0.9 & 133 & 10 & $m$ & 0.17 & 1.07 & intertionate & \\
\hline 1.17 & $3-21-82$ & 38" $20.96^{\circ}$ & $122^{\prime \prime} 79.96^{\circ}$ & 16 & , & 6.62 & $1 \times n$ & 10.0 & 24 & ‘ & 11 & $"$ & .0 .0234 & & o.n. & .0 .250 & $0 .(1 k)$ & 0.20 & 0.07 & .0 .123 & ${ }_{2 n}^{2 n}$ & 0.6 & "' & .10 & 297 & 1.22 & 1.37 & $\begin{array}{l}\text { Myreed cottions - } \\
\text { bicerbonste }\end{array}$ & \\
\hline c. 3 & $1-21-\mathrm{NP}_{2}$ & 2an $20, \mathrm{~m}$ & $1 n^{2} \times 1, \infty$ & $m$ & 10.8 & 1. m & (4) & 9.1 & "1' & "' & !! & I & 0.31 ! & $"$ & $0.011_{1}$ & $0.2 \times 1 \times 1$ & $|0.141|$ & $|-n . m|$ & 0.117 & 1.20 & 101 & 0.1 & $162: 1$ & .10 & 391 & 14.48 & 2.42 & 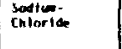 & \\
\hline$c-34$ & $1-1-82$ & $380.20 .78^{\circ}$ & $122^{*} 30.14^{4}$ & $18^{4}$ & 121.9 & 6.91 & 70 & 0.0 & 52 & B & $5 ?$ & 3 & 1.58 & $" 4$ & 0.04 & 0.80 & .0 .063 & 0.125 & $|0.050|$ & 0.40 & 28 & 0.6 & 151 & ${ }^{20}$ & 268 & 0.52 & 1.97 & 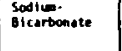 & \\
\hline$c-35$ & $4 \cdot-3-82$ & $3 a^{\circ} 23.98^{\circ}$ & $122^{*} 3.00^{\circ}$ & $x^{*}$ & ? & 6.02 & 160 & 0.0 & is: & 4 & 15 & 10 & 0.025 & 99 & 0.04 & 0.250 & $|0.063|$ & 0.125 & \begin{tabular}{|l|l|} 
& 0.05 \\
\end{tabular} & $-0.125 \mid$ & 8 & $0.3\}$ & 301. & $\therefore$ & 281 & 0.13 & 0.58 & 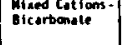 & \\
\hline$c-36$ & $4-4-82$ & $30^{\circ}=19.70^{\circ}$ & $122^{\circ}=89.60^{\circ}$ & $22^{\circ}$ & 19.3 & 5.98 & 170 & 0.0 & 18 & s & 54 & B & 0.18 & 98 & 0.05 & 0.250 & $|0.063|$ & 1.60 & 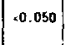 & -0.125 & is! & 0.4 & $102 ! \cdot$ & .10 & 300 & 0.00 & 0.00 & 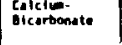 & \\
\hline $\mathrm{c}-3 t$ & 1.4-122 & $36^{\circ} \cdot 17.52^{\circ}$ & $122 \% 88.190^{\circ}$ & ${ }^{19}$ & 22.9 & 6.20 & 110 & 0.0 & ${ }^{63}$ & $\cdot$ & "1 & $n$ & 0.11 & 52 & 0.16 & 0.50 & 0.063 & 1.70 & 0.05 & $0 . \infty$ & 3 & 0.4 & 2ns 1 & .10 & 356 & 2.17 & 1.46 & 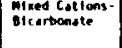 & \\
\hline a. . in & $4-10-20$ & $36 \cdot 16.34$ & $17 n \cdot n \cdot n^{2}$ & 20 & 3.3 & 1.17 & mon & 0.0 & 91 & 3 & ' & $\cdot$ & n. 1 & $*$ & 0.07 & . & 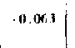 & $\mid 0.123$ & a. (nn & $1 . x$ & "s & $0.8\}$ & $m$. & .10 & 296 & 6.93 & 1.10 & 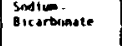 & \\
\hline$\therefore$ & $1.11 \mathrm{~m}$ & $n+\cdots$, & 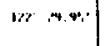 & 211 & $\cdots$ & ...11 & (4) & 1.." & 4 & $1 \vdots$ & 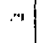 & $m$ & n.11 & " "' & 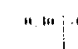 & $(1, \cdots+\infty)$ & n.m. ! & 1.11 & and & . (n. $1 \mathrm{~m}^{\prime}$ & $\because$ & a.1 & $r m !$ & in & $r i 3$ & $1 . m$ & n.9n & 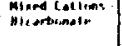 & \\
\hline c. 40 & $1.21-81$ & 38. 19.12 & $122=89.00^{\circ}$ & $33^{\circ}$ & 91.4 & 6.80 & $\cdots$ & 0.2 & is & 9 & 12 & 3 & 0.45 & 6n & 0.04. & $\cdot 0.250$ & .0 .063 & $|-0.125|$ & \begin{tabular}{|l|l|} 
& 0.42 \\
\end{tabular} & 3.4 & 102 & 2.8 & 102. & .10 & 126 & 6.10 & 2.21 & 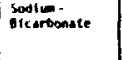 & \\
\hline c. 4 & $1-22-41$ & $36^{\prime \prime} 19.37^{\prime}$ & $127^{\prime \prime} 29.40^{\circ}$ & $2 w$ & 50.3 & 7.10 & $\cdots$ & 0.0 & 53 & $s$ & 4 & 1 & 0.21 & 67 & 0.01 & 0.250 & .0 .063 & .0 .173 & 0.20 & 2.1 & “) & 2.5 & 121 & 4 & 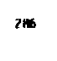 & 6.15 & 1.69 & 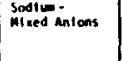 & \\
\hline
\end{tabular}

rooimons

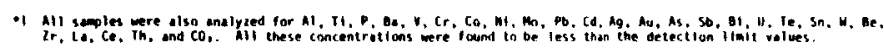

Table 2. Continued. 
Table 3. Mole ratios of major and minor constituents in well waters of Sonoma Valley area, California. By H.H. Majmundar, 1982, CDMG.

\begin{tabular}{|c|c|c|c|c|c|c|c|c|}
\hline $\begin{array}{l}\text { LOCATION } \\
\text { NUMBER } \\
\end{array}$ & $\mathrm{C}] / \mathrm{SO}_{4}$ & $\mathrm{Cl}_{1} \mathrm{HCO}_{3}$ & $(\mathrm{~F} / \mathrm{C} 1) \times 10^{2}$ & $(B / C 1) \times 10^{2}$ & $(\sqrt{\mathrm{Ca}}) / \mathrm{Na}$ & $(\mathrm{K} / \mathrm{Na}) \times 10^{3}$ & $(\mathrm{Li} / \mathrm{Na}) \times 10^{3}$ & $(\mathrm{Mc} / \mathrm{Ca}) \times 10^{2}$ \\
\hline$C-1$ & 3.3 & 0.10 & 3.1 & 5.5 & 8.5 & 213 & 3.5 & 55 \\
\hline$C-2$ & 49 & 0.92 & 0.16 & 0.18 & 6.0 & 13 & 1.3 & 97 \\
\hline$C-3$ & 11 & 0.60 & 0.26 & 0.68 & 3.1 & 8.8 & 0.82 & 109 \\
\hline$C-4$ & 5.2 & 0.40 & 2.4 & 2.4 & 4.7 & 68 & 2.2 & 65 \\
\hline$c-5$ & 2.2 & 0.07 & 4.7 & $N / A$ & 20 & 91 & $N / A$ & 116 \\
\hline$C-6$ & 33 & 1.2 & 0.46 & $N / A$ & 6.6 & 14 & 2.3 & 106 \\
\hline$c-7$ & 5.4 & 0.56 & 1.2 & $\mathrm{H} / \mathrm{A}$ & 10.0 & 11 & $N / A$ & 106 \\
\hline$C-8$ & 19 & 1.3 & 0.74 & $N / A$ & 7.4 & 32 & $N / A$ & 191 \\
\hline$c-9$ & 5.7 & 0.26 & 2.7 & $N / A$ & 15 & 47 & $N / A$ & 272 \\
\hline$C-10$ & 6.2 & 0.26 & 2.4 & 1.9 & 17 & 71 & $N / A$ & 225 \\
\hline$c-11$ & 91 & 8.7 & 0.03 & 0.47 & 2.6 & 4.4 & 0.86 & 82 \\
\hline$c-12$ & 0.98 & 0.24 & 4.4 & 5.8 & 8.5 & 33 & 3.7 & 135 \\
\hline$c-13$ & 1.4 & 0.12 & 7.2 & 25 & 4 & 21 & $N / A$ & 55 \\
\hline$C-14$ & 6.8 & 0.70 & 0.64 & $N / A$ & 30 & 63 & $N / A$ & 126 \\
\hline$c-15$ & 2.7 & 0.17 & 3.4 & 15 & 7.4 & 24 & 2.7 & 65 \\
\hline$C-16$ & 2.5 & 0.20 & 3.9 & 3.5 & 8.3 & 94 & 13 & 128 \\
\hline$c-17$ & 1.1 & 0.12 & 74 & $N / A$ & 14 & 98 & $\mathrm{~N} / \mathrm{A}$ & 124 \\
\hline C- 18 & 3.5 & 0.19 & 8.6 & 5 & 11 & 74 & $N / A$ & 92 \\
\hline$C-19$ & 2.7 & 0.14 & 13 & $N / A$ & 17 & 68 & $N / A$ & 77 \\
\hline$c-20$ & 1.6 & 0.07 & 9.3 & 11 & 70 & 11 & $N / A$ & 97 \\
\hline$C-21$ & 2.4 & 0.14 & 12 & $N / A$ & 45 & 82 & $N / A$ & 37 \\
\hline$C-22$ & 2.2 & 0.13 & 12 & $N / A$ & 12 & 63 & $N / A$ & 83 \\
\hline$C-23$ & 3.3 & 0.15 & 9.3 & 8.2 & 3.2 & 58 & 4.6 & $N / A$ \\
\hline$c-24$ & 2.4 & 0.13 & 4.2 & 7.3 & 64 & 58 & $N / A$ & 62 \\
\hline$C-25$ & 0.20 & 0.41 & 15 & $N / A$ & 32 & 441 & $N / A$ & 99 \\
\hline$C-26$ & 5.7 & 0.47 & 1.0 & 7.6 & 7.7 & 71 & 22 & 121 \\
\hline$C-27$ & 4.1 & 0.18 & 5.0 & $N / A$ & 16 & 26 & $N / A$ & 69 \\
\hline$C-28$ & 10 & $0 . z 2$ & 1.5 & 1.7 & 9.3 & 40 & $N / A$ & 187 \\
\hline$C-29$ & 2.4 & 0.13 & 12.4 & $N / A$ & 13 & 12 & $N / A$ & 103 \\
\hline$c-30$ & 5.4 & 0.21 & 1.8 & $N / A$ & 29 & 39 & $N / A$ & 94 \\
\hline$c-3]$ & 14 & 0.65 & 3.3 & 5.9 & 6.2 & 12 & 2.7 & 55 \\
\hline$c-32$ & 7.6 & 0.43 & 4.0 & $N / A$ & 16 & 12 & 9.6 & 165 \\
\hline$c-33$ & 27 & 1.1 & 1.3 & 10 & 1.8 & 52 & 1.8 & 55 \\
\hline$C-34$ & 7.6 & 0.32 & 4.0 & 4.7 & 4.9 & 90 & $N / A$ & 55 \\
\hline$c-35$ & 1.1 & 0.10 & 7.0 & $N / A$ & 30 & 157 & 11 & 110 \\
\hline$c-36$ & 4.1 & 0.25 & 5.0 & $N / A$ & 47 & 163 & $\mathrm{~N} / \mathrm{A}$ & 24 \\
\hline$[-37$ & 10 & 0.23 & 2.0 & 3.4 & 10 & 37 & 2.5 & 106 \\
\hline$C-38$ & 4.1 & 0.09 & 7.4 & 28 & 3.3 & 19 & 2.9 & 94 \\
\hline$C-39$ & 4.6 & 0.15 & 3.3 & $N / A$ & 14 & 40 & 4.3 & 57 \\
\hline$C-40$ & 39 & 1.4 & 3.7 & 7.8 & 4.2 & 56 & 14 & 28 \\
\hline$C-41$ & 2.9 & 0.66 & 10 & 15 & 4.3 & 55 & 12 & 47 \\
\hline
\end{tabular}


the water type designated as mixed cations-bicarbonate was found in the samples collected. All designated water types are found east of this line.

- Twenty samples have sodium ( $\mathrm{Na}$ ) concentrations greater than or equal to 50 $\mathrm{mg} / 1$ (Locations No. C-2, C-3, C-6, C-8, C-11, C-12, C-13, C-15, C-16, C-23. $\mathrm{C}-26, \mathrm{C}-28, \mathrm{C}-31, \mathrm{C}-33, \mathrm{C}-34, \mathrm{C}-37, \mathrm{C}-38, \mathrm{C}-40$, and $\mathrm{C}-41)$. All of these sample locations except Locations No. C-28 and $\mathrm{C}-37$ lie to the east of the "diamond" line on Plate 7.

- Wells having water samples with sodium (Na) concentrations greater than 50 $\mathrm{mg} / \mathrm{l}$ and classified by water type as either sodium-bicarbonate or sodium-chloride are along or are located very near the alignment of the fault on the east side of Sonoma Valley. These include Locations No. C-23, C-26, C-31, $\mathrm{C}-34, \mathrm{C}-40$, and $\mathrm{C}-4 \mathrm{l}$. Likewise, at Boyes Hot Springs along the same fault (Plate 7), Herbst (1982) says ". . highly mineralized thermal water ... poses a severe sodium problem."

There probably are several other comparisons or distributional patterns of water types and mineral concentrations that can be made from Tables 2 and 3 . The above features were noted without emphasis to depth of well or temperature of water. Nevertheless, the general trends described above seem valid for the sample population.

\section{Discussion}

Barnes (1970) suggests that the presence of boron (B) in geothermal fluids indicates those fluids may have escaped along faults. There appears to be geothermal water with relatively high boron concentrations along the proposed "east side" fault on the east side of Sonoma Valley described elsewhere in this report. This presence of boron may further add to the proof of the existence of this fault.

There appears to be a general segregation of water types to the east and west sides of Sonoma Valley. This may reflect on the differing recharge areas (the mountains to the east and to the west of Sonoma Valley), different subsurface travel paths of fluids, and/or the presence of subsurface water barriers associated with the northwest trend of the fault fabric in the Sonoma Valley.

Perhaps there may be an upwelling of sorts or migration of thermal fluids along the "east side" fault in Sonoma Valley. This may be evidenced by the higher concentrations of sodium ( $\mathrm{Na}$ ) and boron (B) along this trace. Higher concentrations of sodium ( $\mathrm{Na}$ ) and other constituents in samples from the southeast corner of the map area (Plate 7) are probably due to salt water intrusion from the bay area.

Generally waters with the higher Total Dissolved Solids (T.D.S.) appear to be on the east side of the valley. Geothermal fluids are characterized by higher T.D.S. Therefore, the east side of the Sonoma Valley may be nearer to or contain the larger geothermal resources. 


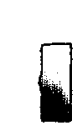

.

.

$\nabla$

.

$\triangle$

.

$\nabla$

D

จ

D

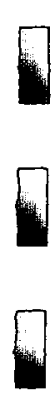

.

.

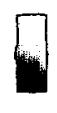

. 
Introduction

The use of chemical geothermometers (geothermometry) is one method of estimating the temperature conditions of a geothermal fluids reservoir. Geothermometry algorithms are based on temperature and pressure dependent water-rock reactions which determine the chemical and isotopic composition of geothermal fluids. The most common soluble chemical constituents of thermal waters are $\mathrm{SiO}_{2}, \mathrm{Na}, \mathrm{K}, \mathrm{Ca}, \mathrm{Mg}, \mathrm{Cl}, \mathrm{HCO}$, and $\mathrm{CO}_{3}$. The three most generally used geothermometers are the silica, Na-K-Ca, and sulfate-isotope geothermometers. Several conditional assumptions must be made before using chemical compositions of spring and well waters to calculate subsurface temperatures via geothermometry:

1. Temperature-dependent reactions at depth, control the dissolved chemical concentrations of elements used in a particular geothermometer.

2. The reservoir contains a sufficient supply of the reactants.

3. Water-rock equilibrium is established in the reservoir for the specific elemental concentrations to be employed in the geothermometry.

4. The constituents used in the geothermometer do not re-equilibrate with the confining rock as the fluids leave the reservoir to the surface or to the point at which the sample is collected.

5. Mixing of thermal and nonthermal groundwater does not occur or, if it does, an accurate mixing model can be established.

Problems and inaccuracies arise with the calculated reservoir temperature from a geothermometer when one or more of the above assumptions are violated. The geochemical data gathered for this report (Table 4) come predominately from wells that were drilled for a fresh or cold water supply. Typically, these wells are perforated over a large percentage of their total depth to maximize water production. The waters in such wells could be a mixture of water from distinct aquifers. If one or more of these aquifers contained geothermal fluids, those fluids would then be mixed (at unknown proportions) with waters from fresh water aquifers. Also, some wells undoubtedly are so shallow as to only encounter shallow groundwater tables and do not intersect geothermal aquifers. Such conditions do not conform to the five basic assumptions required for adequate geothermometry calculated reservoir temperatures. Hence, the geothermometric results presented below should be considered with great care and some skepticism.

\section{Methodology}

CDMG was able to obtain 41 water samples from cold and warm water wells and warm springs in the Sonoma Valley. The concentrations of $\mathrm{SiO}_{2}, \mathrm{Na}, \mathrm{K}, \mathrm{Ca}$ and $\mathrm{Mg}$ for each sample, regardless of the surface temperature, were entered into the "FORTRAN Program to Compute Chemical Geothermometers for Geothermal Fluids" (Rapport, 1982) that is available in the CDMG computer program library. The results are tabulated in Table 4. The chemical samples are labeled $\mathrm{C}-1$ through $\mathrm{C}-41$ and correspond to the locations shown on Plate 7. 
Table 4.

GEOTHERMOMETRY TEMPERATURE VALUES $\left({ }^{\circ} \mathrm{C}\right)$ FOR

SELECTED WATER WELLS AND SPRINGS IN THE SONOMA VALLEY AREA, SONOMA COUNTY, CALIFORNIA

\begin{tabular}{|c|c|c|c|c|c|c|c|c|c|c|c|}
\hline \multirow[b]{2}{*}{$\begin{array}{l}\text { LOCATION } \\
\text { NUMBER }\end{array}$} & \multirow{2}{*}{$\begin{array}{c}\text { SURFACE } \\
\text { TEMPERATURE } \\
\left({ }^{\circ} C\right)\end{array}$} & \multirow{2}{*}{\multicolumn{5}{|c|}{ SILICA }} & \multirow[b]{2}{*}{$\mathrm{Na}-\mathrm{K}$} & \multirow[b]{2}{*}{$\begin{array}{c}\mathrm{Na}-\mathrm{K}-\mathrm{Ca} \\
(1 / 3) \\
\end{array}$} & \multirow[b]{2}{*}{$\begin{array}{c}N a-K-C a \\
(4 / 3) \\
\end{array}$} & \multicolumn{2}{|c|}{ Mg CORRECTED } \\
\hline & & & & & & & & & & $\begin{array}{c}N a-k-c a \\
(1 / 3) \\
\end{array}$ & \begin{tabular}{|l}
$\mathrm{Na}-\mathrm{K}-1$ \\
.$(4 / 3$ \\
\end{tabular} \\
\hline$c-1$ & $28^{\circ}$ & $138=$ & $134^{=}$ & $112^{\circ}$ & $88^{\circ}$ & $18^{\circ}$ & $292^{\circ}$ & $238^{=}$ & $124=$ & $86^{\circ}$ & $71^{\circ}$ \\
\hline$c-2$ & $17^{\circ}$ & $88^{\circ}$ & $97^{\circ}$ & $57^{\circ}$ & $38^{\circ}$ & $-26^{2}$ & $89^{\circ}$ & $103^{\mathrm{c}}$ & $46=$ & $27^{\circ}$ & $\cdots$ \\
\hline$c-3$ & $16^{\circ}$ & $79^{\circ}$ & $83^{\circ}$ & $48=$ & $30^{\circ}$ & $-33^{\circ}$ & $146^{\circ}$ & $158^{\circ}$ & $109=$ & $20^{\circ}$ & $27=$ \\
\hline$C-4$ & $32^{\circ}$ & $133^{\circ}$ & $129=$ & $105^{\circ}$ & $82^{c}$ & $13^{*}$ & $186=$ & $180^{\circ}$ & $110=$ & $48^{:}$ & $52^{*}$ \\
\hline$c-5$ & $23^{\circ}$ & $136^{\circ}$ & $131^{2}$ & $109^{\circ}$ & $85^{\circ}$ & $15^{\circ}$ & $209^{\circ}$ & $170^{\circ}$ & $56^{2}$ & --- & $\cdots$ \\
\hline$C-6$ & $20^{\circ}$ & $101^{\circ}$ & $102^{=}$ & $71^{\circ}$ & $50^{\circ}$ & $-15=$ & $90^{\circ}$ & $103^{\circ}$ & $43^{\circ}$ & --- & -.. \\
\hline$c-7$ & $16^{3}$ & $136^{\circ}$ & $132^{\circ}$ & $109^{\circ}$ & $85^{\circ}$ & $16=$ & $80^{\circ}$ & $90^{\circ}$ & $24=$ & $\cdots$ & $\cdots$ \\
\hline$c-8$ & $16^{\circ}$ & $137^{\circ}$ & $132^{\circ}$ & $110^{\circ}$ & $86^{\circ}$ & $16^{\circ}$ & $135^{\circ}$ & $135^{\circ}$ & $63^{3}$ & -- & -- \\
\hline$c-9$ & $18^{\circ}$ & $126^{\circ}$ & $124^{\circ}$ & $99^{\circ}$ & $76^{\circ}$ & $7^{\circ}$ & $160^{\circ}$ & $143^{\circ}$ & $47^{\circ}$ & -- & -.. \\
\hline$C-10$ & $11^{\circ}$ & $123^{\circ}$ & $121=$ & $95^{\circ}$ & $72^{\circ}$ & $4^{\circ}$ & $189^{\circ}$ & $160^{\circ}$ & $54^{*}$ & -- & $\cdots$ \\
\hline C-11 & $10^{\circ}$ & $65^{\circ}$ & $71^{\circ}$ & $33^{\circ}$ & $16^{\mathrm{c}}$ & $-45^{\circ}$ & $43^{\circ}$ & $74^{\circ}$ & $47^{\circ}$ & $42^{\circ}$ & --. \\
\hline$C-12$ & $19^{\circ}$ & $158^{\circ}$ & $150^{\circ}$ & $134^{\circ}$ & $107^{\circ}$ & $36=$ & $137^{\circ}$ & $135^{\circ}$ & $59^{\circ}$ & -- & -.- \\
\hline$C-13$ & $19^{\circ}$ & $104^{\circ}$ & $104^{=}$ & $74^{\circ}$ & $53^{\circ}$ & $-12^{\circ}$ & $111=$ & $126^{\circ}$ & $76=$ & $52^{\prime}$ & $66^{=}$ \\
\hline$C-14$ & $17^{\circ}$ & $118^{\circ}$ & $117^{=}$ & $90^{\circ}$ & $68^{\circ}$ & $0=$ & $180^{\circ}$ & $146^{\circ}$ & $311^{\circ}$ & -. & -. \\
\hline$c-15$ & $14^{\circ}$ & $116^{\circ}$ & $115^{2}$ & $87^{\circ}$ & $65^{\circ}$ & $-2=$ & $119=$ & $123^{\circ}$ & $55^{2}$ & $39^{\circ}$ & $\cdots$ \\
\hline$C-16$ & $17^{\circ}$ & $136^{\circ}$ & $132^{\circ}$ & $109^{\circ}$ & $85^{\circ}$ & $16^{\circ}$ & $212^{\circ}$ & $188^{\circ}$ & $94^{\circ}$ & $17=$ & $29=$ \\
\hline$c-17$ & $29^{\circ}$ & $127^{\circ}$ & $124^{\circ}$ & $99=$ & $76^{\circ}$ & $8^{\circ}$ & $215^{\circ}$ & $181^{\circ}$ & $73=$ & $16=$ & $35^{\circ}$ \\
\hline$C-18$ & $30^{\circ}$ & $140^{\circ}$ & $135^{=}$ & $114=$ & $90^{\circ}$ & $20=$ & $192^{\circ}$ & $170^{\circ}$ & $74^{\circ}$ & $26=$ & $45^{\circ}$ \\
\hline$C-19$ & $23^{\circ}$ & $127^{\circ}$ & $124^{\circ}$ & $99^{c}$ & $76^{\circ}$ & $8^{3}$ & $186^{3}$ & $158^{\circ}$ & $53^{2}$ & $29=$ & $\cdots$ \\
\hline$C-20$ & $15^{\circ}$ & $72^{\circ}$ & $77^{2}$ & $40^{\circ}$ & $23^{c}$ & $-39=$ & $226=$ & $159^{\circ}$ & $18^{=}$ & $18=$ & $\ldots$ \\
\hline$(-2)$ & $21^{\circ}$ & $113^{\circ}$ & $112^{2}$ & $84^{\circ}$ & $62^{\circ}$ & $-4^{\circ}$ & $200^{\circ}$ & $151^{\circ}$ & $25^{\circ}$ & $64=$ & $\cdots$ \\
\hline$C-22$ & $28^{\circ}$ & $132^{\circ}$ & $128=$ & $105^{c}$ & $81^{\circ}$ & $12^{\circ}$ & $180^{2}$ & $161^{\circ}$ & $66=$ & $29=$ & $52^{=}$ \\
\hline$c-23$ & $30^{\circ}$ & $104^{\circ}$ & $104^{=}$ & $74^{\circ}$ & $53^{\circ}$ & $-12^{c}$ & $174^{=}$ & $179^{\circ}$ & $124=$ & $\cdots$ & $\cdots$ \\
\hline$C-24$ & $24^{\circ}$ & $63^{\circ}$ & $69=$ & $31^{\circ}$ & $14^{\circ}$ & $-46^{\circ}$ & $219^{\circ}$ & $157^{\circ}$ & $19=$ & $\cdots$ & $\cdots$ \\
\hline$c-25$ & $14^{\circ}$ & $87^{\circ}$ & $90^{\circ}$ & $56^{\circ}$ & $37^{\circ}$ & $-26^{\circ}$ & $389=$ & $259^{\circ}$ & $85^{2}$ & $49=$ & $49=$ \\
\hline$c-26$ & $17^{\circ}$ & $111^{\circ}$ & $110=$ & $81^{\circ}$ & $60^{\circ}$ & $-7^{\circ}$ & $189^{\circ}$ & $174^{\circ}$ & $87^{*}$ & $16^{\circ}$ & $30^{\circ}$ \\
\hline$C-27$ & $27^{\circ}$ & $111^{\circ}$ & $111=$ & $82^{\circ}$ & $61^{\circ}$ & $-6^{\circ}$ & $123^{\circ}$ & $116^{\circ}$ & $31=$ & $36=$ & -.. \\
\hline$C-28$ & $16^{\circ}$ & $110^{\circ}$ & $109=$ & $80^{\circ}$ & $59^{\circ}$ & $-7=$ & $150^{\circ}$ & $143^{\circ}$ & $61=$ & $\cdots$ & $\cdots$ \\
\hline$C-29$ & $21^{\circ}$ & $135^{\circ}$ & $131=$ & $108^{\circ}$ & $84^{\circ}$ & $15^{\circ}$ & $231^{\circ}$ & $192^{\circ}$ & $81=$ & $25=$ & $41=$ \\
\hline$c-30$ & $17^{\circ}$ & $113^{\mathrm{c}}$ & $112=$ & $84^{\circ}$ & $62^{\circ}$ & $-4^{\circ}$ & $148^{\circ}$ & $125^{\circ}$ & $21=$ & $22=$ & -.. \\
\hline$C-31$ & $22^{\circ}$ & $122^{\circ}$ & $120=$ & $94^{\circ}$ & $72^{\circ}$ & $4^{2}$ & $230^{\circ}$ & $206^{\circ}$ & $116^{=}$ & $73^{\circ}$ & $68^{\circ}$ \\
\hline$c-32$ & $16^{\circ}$ & $141^{\circ}$ & $136=$ & $115^{\circ}$ & $90^{\circ}$ & $20=$ & $235^{\circ}$ & $191^{\circ}$ & $73^{=}$ & $\cdots$ & -- \\
\hline$C-33$ & $21^{\circ}$ & $119^{\circ}$ & $117^{\circ}$ & $90^{\circ}$ & $68^{\circ}$ & $1^{\circ}$ & $167^{\circ}$ & $184^{\circ}$ & $155^{=}$ & $102=$ & $96=$ \\
\hline$C-34$ & $18^{\circ}$ & $121^{\circ}$ & $119=$ & $93^{\circ}$ & $70^{\circ}$ & $3^{e}$ & $209^{\circ}$ & $195^{\circ}$ & $118=$ & $42=$ & $45^{=}$ \\
\hline$C-35$ & $20^{\circ}$ & $137^{\circ}$ & $132^{\circ}$ & $110^{\circ}$ & $86^{\circ}$ & $16^{\circ}$ & $259^{\circ}$ & $193^{\circ}$ & $56^{\circ}$ & $17^{\circ}$ & $44^{\circ}$ \\
\hline$c-36$ & $22^{\circ}$ & $136^{\circ}$ & $132=$ & $109^{\circ}$ & $85^{\circ}$ & $16^{\circ}$ & $263^{\circ}$ & $186^{\circ}$ & $40=$ & $94^{\circ}$ & $\cdots$ \\
\hline$C-37$ & $19^{\circ}$ & $108^{\circ}$ & $108^{=}$ & $79^{\circ}$ & $58^{\circ}$ & $-9^{\circ}$ & $145^{2}$ & $138^{\circ}$ & $56=$ & $18^{\circ}$ & $43=$ \\
\hline$C-38$ & $20^{\circ}$ & $89^{\circ}$ & $92=$ & $59^{\circ}$ & $39^{\circ}$ & $-25^{\circ}$ & $107^{\circ}$ & $125^{\circ}$ & $81^{\circ}$ & $28^{\circ}$ & $41=$ \\
\hline$c-39$ & $20^{\circ}$ & $79^{\circ}$ & $83^{*}$ & $48^{2}$ & $30^{\circ}$ & $-33^{c}$ & $149^{\circ}$ & $137^{\circ}$ & $46^{\circ}$ & $42^{c}$ & $\cdots$ \\
\hline$c-40$ & $35^{\circ}$ & $117^{\circ}$ & $115^{\circ}$ & $88^{\circ}$ & $66^{\circ}$ & $-1^{\circ}$ & $172^{\circ}$ & $172^{\circ}$ & $108^{\circ}$ & $101^{c}$ & $95^{\circ}$ \\
\hline 0.41 & $29^{\circ}$ & $116^{\circ}$ & $115^{\circ}$ & $87^{\circ}$ & $65^{\circ}$ & $-2^{\circ}$ & $171^{\circ}$ & $171^{\circ}$ & $106^{=}$ & $86^{=}$ & $84=$ \\
\hline
\end{tabular}


below:

The algorithms used in the computer program are those of Fournier (1977) as given

\section{GEOTHERMOMETERS}

Silica

Quartz (conductive)

${ }^{\circ} \mathrm{C}=\frac{1309}{5.19-\log \mathrm{SiO}_{2}}-273.15$

Quartz (adiabatic)

${ }^{\circ} \mathrm{C}=\frac{1522}{5.75-\log \mathrm{SiO}_{2}}-273.15$

Chalcedony

${ }^{\circ} \mathrm{C}=\frac{1032}{4.69-\log \mathrm{SiO}_{2}}-273.15$

Alpha-cristobalite

${ }^{\circ} \mathrm{C}=\frac{1000}{4.78-\log \mathrm{SiO}_{2}}-273.15$

Amorphous silica

${ }^{\circ} \mathrm{C}=\frac{731}{4.52-\log \mathrm{SiO}_{2}}-273.15$

All concentrations are in $\mathrm{mg} / 1$ or $\mathrm{ppm}$.

Cations

$\mathrm{Na}-\mathrm{K}$

$\mathrm{Na}-\mathrm{K}-\mathrm{Ca}$
${ }^{\circ} \mathrm{C}=\frac{1217}{\log (\mathrm{Na} / \mathrm{K})+1.483}$

$-273.15$

$-273.15$

Where $B$ is either $1 / 3$ or $4 / 3$.

A correction is made to the $\mathrm{Na}-\mathrm{K}-\mathrm{Ca}$ geothermometers for the $\mathrm{Mg}$ content of the solution if the ratio of $\mathrm{Mg} /(\mathrm{Mg}+\mathrm{Ca}+\mathrm{K})$ is greater than 0.5 and less than 50. The criteria, procedure, and algorithms for application of this correction are given in Fournier and Potter (1978). This correction is automatically applied by the computer program when the criteria are fulfilled. When the $\mathrm{Na}-\mathrm{K}-\mathrm{Ca}$ geothermometer requires this correction it appears on the right side of Table 4 under the heading " $\mathrm{Mg}$ CORRECTED" for both $B=1 / 3$ and $B=4 / 3$.

Bowen (1979) lists the quartz geothermometer best suited to the temperature range of $150^{\circ}-225^{\circ} \mathrm{C}\left(302^{\circ}-437^{\circ} \mathrm{F}\right)$, the $\mathrm{Na}-\mathrm{K}$ geothermometer works best for temperatures of waters above $200^{\circ} \mathrm{C}\left(392^{\circ} \mathrm{F}\right)$, and the Na-K-Ca geothermometer is best suited for water equilibrated around $100^{\circ} \mathrm{C}\left(212^{\circ} \mathrm{F}\right)$. With the above in mind the temperature values for the $\mathrm{Na}-\mathrm{K}-\mathrm{Ca}(\mathrm{B}=4 / 3)$ and the $\mathrm{Mg}$ corrected $\mathrm{Na}-\mathrm{K}-\mathrm{Ca}(\mathrm{B}=1 / 3)$ geothermometers from Table 4 were chosen to be contoured on Plates 8 and 9 respectively. All values from these two geothermometers were utilized regardless of the depth of well or whether or not a well was considered to be a geothermal well.

\section{Results}

Geothermometry temperature values from the far right three columns of Table 4 were averaged utilizing only those wells or springs with surface temperature greater than or equal to $20^{\circ} \mathrm{C}\left(68^{\circ} \mathrm{F}\right)$ with the following results: 
Geothermometer

$\mathrm{Na}-\mathrm{K}-\mathrm{Ca}(\mathrm{B}=4 / 3)$

$\mathrm{Mg}$ Corrected $\mathrm{Na}-\mathrm{K}-\mathrm{Ca}(\mathrm{B}=1 / 3)$

MG Corrected Na-K-Ca $(B=4 / 3)$
Average Temperature

$77^{\circ} \mathrm{C}\left(171^{\circ} \mathrm{F}\right)$

$52^{\circ} \mathrm{C}\left(126^{\circ} \mathrm{F}\right)$

$60^{\circ} \mathrm{C}\left(140^{\circ} \mathrm{F}\right)$

The reservoir temperature of geothermal resources in the Sonoma Valley area may be in the range of the average temperatures indicated above. However, several of the other geothermometers in Table 4 show temperature values somewhat higher than these averages.

Plate 8 shows the results of manually contouring the reservoir temperature values derived from the Na-K-Ca $(B=4 / 3)$ geothermometer. The dominant feature is the $100^{\circ} \mathrm{C}$ closed elongate, contour trending north-northwest from the City of Sonoma along the east side of Sonoma Valley. This area of "hotter" reservoir temperature probably approximates the "warm water belt" described by Bradley (1915). The contour also subparallels the "east side" fault alignment developed from gravity surveys discussed elsewhere in the report. The implication is that this fault structure has some influence on the location of this "hotter" zone.

Plate 9 presents the results of manually contouring the reservoir temperatures calculated from the $\mathrm{Mg}$ corrected $\mathrm{Na}-\mathrm{K}-\mathrm{Ca}(\mathrm{B}=1 / 3)$. Quite a different concept of reservoir temperature is suggested by the contours on Plate 9. The contour gradient increasing eastwardly suggests the greatest geothermal reservoir temperatures lie to the northeast and east of the Sonoma Valley perhaps under or within the Sonoma Volcanic units that form the mountainous terrain in this area.

\section{Conclusions}

The reliability of the geothermometry calculations for the Sonoma Valley area may be questionable. Nevertheless, the calculations presented in Table 4, may indicate a geothermal reservoir temperature in the $52^{\circ}-77^{\circ} \mathrm{C}\left(126^{\circ}-171^{\circ} \mathrm{F}\right)$ range, although some geothermometer indicators show temperatures may be higher than this.

Plates 8 and 9 show two different interpretations of the character of the geothermal reservoir. The Na-K-Ca $(B=4 / 3)$ geothermometer (Plate 8) may indicate a north-northwest trending reservoir "hot spot" in association with a fault on the east side of Sonoma Valley. Perhaps a geothermal fluids "plume" or up-welling occurs along this fault trace. However, the $\mathrm{Mg}$ corrected $\mathrm{Na}-\mathrm{K}-\mathrm{Ca}(\mathrm{B}=1 / 3)$ geothermometer (Plate 9) may be indicating a buried heat source beneath the volcanic mountains northeast of the Sonoma Valley.

These two apparent interpretive discrepancies are probably the result of the unreliability of the geothermometric calculations applied to this area as described above. This problem points out the inadequacy of relying upon one investigative technique to supply the definitive assessment of a geothermal resource.

Chemical analyses and subsequent geothermometry calculations performed for water samples wholly obtained from geothermal aquifers in the Sonoma Valley area should improve the reliability of the results and may, in fact, indicate higher reservoir temperature than calculated above. 


\section{DIRECT TEMPERATURE MEASUREMENTS OF \\ THE SONOMA VALLEY GEOTHERMAL AREA}

\section{Introduction}

Probably the most important physical property of a low- and moderate-temperature geothermal reservoir is its temperature. Wells and springs with water temperatures greater than $20^{\circ} \mathrm{C}\left(68^{\circ} \mathrm{F}\right)$ are considered to be geothermal by CDMG standards. Several methods were employed to collect direct temperature measurements of the geothermal resources in the Sonoma Valley area.

\section{Methodology}

Locations of known geothermal wells and springs and their temperatures for the Sonoma Valley area were researched in existing literature. Waring (1915), Bradley (1915), Berkstresser (1968), Blaydes (1981) and Leivas and others (1981) are some of the sources for historic locations of geothermal features in the area. All temperatures found reported in these publications were considered to be surface discharge water temperatures unless otherwise recorded.

Other temperature and location data of geothermal wells were obtained from private and university geothermal consultants that were currently working on projects in the Sonoma Valley area.

Also, CDMG recorded surface discharge temperatures with a standard hand held maximum recording thermometer while collecting water samples from selected water wells and springs.

CDMG was also able to record downhole water temperatures in a few geothermal wells during a limited field season. These wells were measured by manually lowering a thermister tipped temperature probe attached to 152 meters (500 feet) of graduated electrical conducting cable. The temperature was recorded on an attached Johnson-Keck, Model DTM-75, digital temperature meter. Later these data were drafted on temperature logs depicting graphs of water temperature versus depth of probe penetration in each well.

\section{Results}

A listing of geothermal wells and springs known to CDMG to date for the Sonoma Valley area is provided in Table 5 and on Plate 1. Table 5 lists twenty-six geothermal wells and three geothermal springs. Note, however, that Location No. S-22 may be erroneously located and may in fact be the location labeled "Sonoma State Hospital warm well" on Plate 1.

The surface discharge geothermal temperatures on Table 5 range from $20^{\circ} \mathrm{C}\left(68^{\circ} \mathrm{F}\right)$ to $35^{\circ} \mathrm{C}\left(95^{\circ} \mathrm{F}\right)$. The greatest surface temperature was measured in the discharge of a well at Agua Caliente Springs (Location No. C-40, Plate 1). Historically, however, water discharging from wells at Boyes Hot Springs to the south-southeast of Agua Caliente Springs was approximately $44^{\circ} \mathrm{C}\left(112^{\circ} \mathrm{F}\right)$. However, the wells are currently abandoned at that site and are no longer artesian. No surface temperatures could be recorded there.

Fourteen of the entries in Table 5 have either surface temperatures or a downhole temperature greater than $25^{\circ} \mathrm{C}\left(77^{\circ} \mathrm{F}\right)$. The majority of these "hotter" geothermal wells are within the long known "warm water belt" (Bradley, 1915) that includes part of the City of Sonoma and extends north-northwest up the east side of the Sonoma Valley. (Locations No. C-17, C-18, C-22, C-23, C-40, C-41, "Boyes Hot Springs No. 1", "Boyes Hot Springs 
Table 5. Direci temperature MEASUREMENTS OF SElected GeOtherMal wELLS A.NO SPRINGS (TEMPERATURE $\geq 20 . \mathrm{C}$ ) in ite sonoma valley area, sonoma ano napa counties, califormia

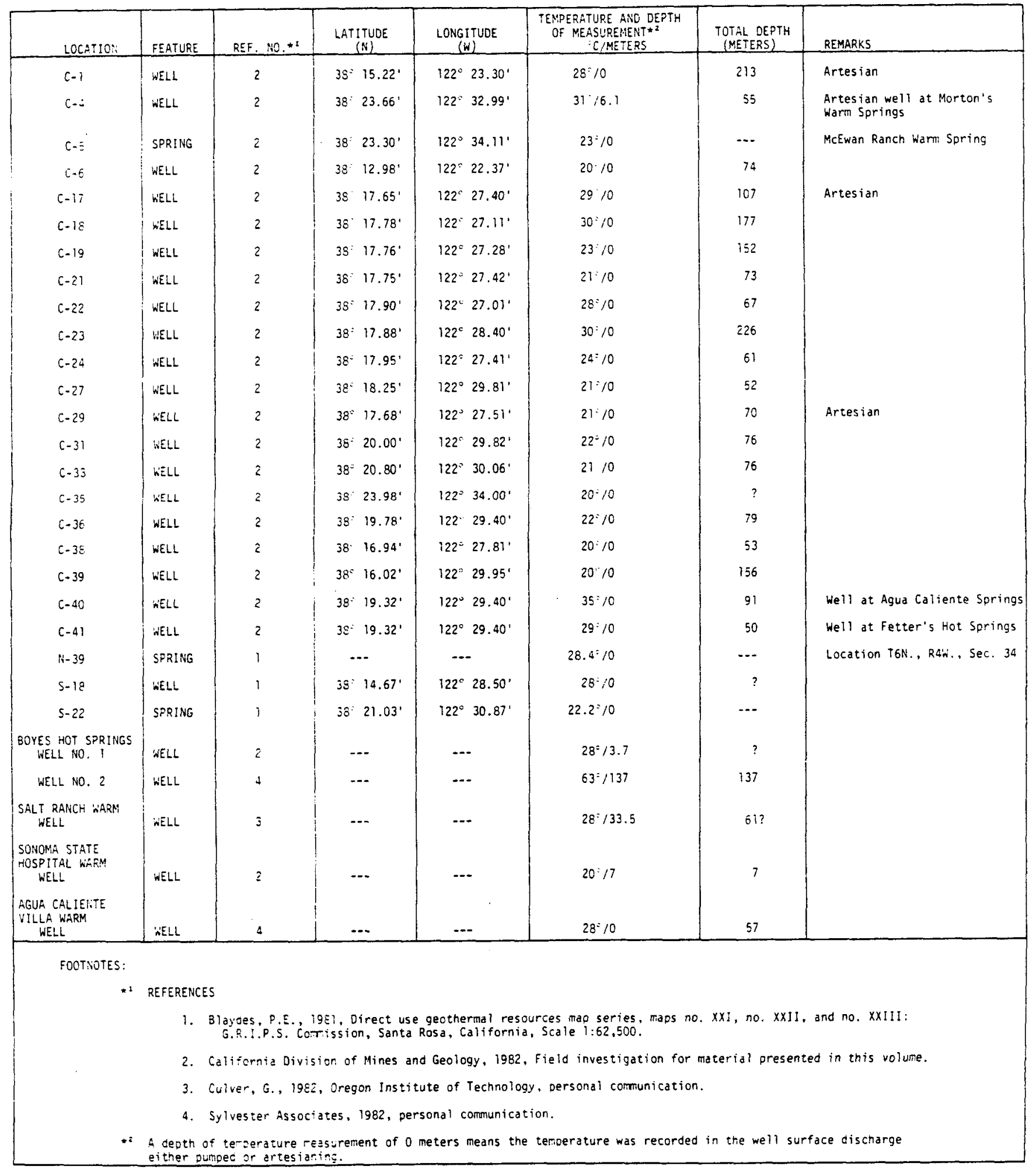


No. 2", and "Agua Caliente Villa warm well," Plate 1). The remainder of the "hotter" geothermal surface features are scattered about the map area of Plate 1 (Locations No. $\mathrm{C}-1, \mathrm{C}-4, \mathrm{~N}-39, \mathrm{~S}-18$, and the "Salt Ranch warm well").

To date, downhole temperature data have been acquired for five known geothermal wells (Locations No. C-4. "Sonoma State Hospital warm well". "Agua Caliente Villa warm well", "Boyes Hot Springs No. 2", and the "Salt Ranch warm well", Plate 1). The data have been plotted in graphical format and are presented in Figures 27-31 respectively.

Figure 27 is a temperature profile of an artesian well at the Morton's Warm Spring site. The maximum temperature is only slightly higher than $31^{\circ} \mathrm{C}\left(88^{\circ} \mathrm{F}\right)$. The maximum temperature occurs in a zone from approximately 5-12.5 meters (16-41 feet) deep in the well. The temperature curve reverses thereafter to a bottom hole temperature of approximately $29.1^{\circ} \mathrm{C}\left(84^{\circ} \mathrm{F}\right)$ at 37.5 meters $(123 \mathrm{feet})$. The temperature profile may indicate that the warmer water-bearing aquifer is quite shallow at this site and may be underlain by one or more cooler aquifers at least to the depth of the well probed.

Figure 28 is the temperature curve from a shallow, hand dug, 3.1 meter (10 foot) diameter well on the farm area of the Sonoma State Hospital grounds. It is thought that this site is the warm spring described in historic literature at the old State Home at Eldridge (Waring, 1915). Although the maximum temperature is only $20.3^{\circ} \mathrm{C}\left(68.5^{\circ} \mathrm{F}\right)$ at a bottom hole depth of 7 meters (23 feet), nevertheless, the bottom of the temperature profile indicates an increase in temperature with depth after initially showing a reverse condition down to the 6 meter (20 foot) depth.

On Figure 29 the maximum temperature of the Agua Calienta Villa warm well is $26^{\circ} \mathrm{C}$ $\left(79^{\circ} \mathrm{F}\right)$ at 57.3 meters $(188 \mathrm{feet})$. A straight line was manually fitted to the deepest five temperature values (dots on curve) and the graphical intercepts of the line were visually determined. Simple calculations show that the temperature gradient in the Agua Caliente Villa warm well is approximately $28^{\circ} \mathrm{C} / 100$ meters from 40 meters $(131$ feet) to the bottom of the well. results:

Sylvester Associates (1982) had tests performed on this well with the following

"The well was blown for a total of two hours. Flow was very good and estimated to be greater than $200 \mathrm{gpm}$. The water had a strong hydrogen sulfide odor from the beginning and was still evident but weaker at the end of the pumping. The water delivery temperature was measured at $82.5^{\circ} \mathrm{F}\left(28^{\circ} \mathrm{C}\right)$ at the well head after two hours of pumping. Prior to leaving the site a bottom hole reading at $188 \mathrm{FT}(57.3 \mathrm{~m})$ read $78.8^{\circ} \mathrm{F}\left(26^{\circ} \mathrm{C}\right)$ indicating the well bottom temperature had returned to its original condition."

It is not uncommon to gain an increase in water temperature in low- to moderate-temperature geothermal wells as a result of heavy pumping on the well.

Figure 30 is an unconfirmed temperature curve from one of the abandoned wells at Boyes Hot Springs. It is thought that this curve is from the well designated "Boyes Hot Springs well No. 2" by CDMG on Plate 1. The curve implies an ever increasing water temperature with depth at least to the bottom of the hole at 137.2 meters ( 450 feet) where $62.7^{\circ} \mathrm{C}\left(145^{\circ} \mathrm{F}\right)$ was supposedly recorded. 
Figure 27.

CALIFORNIA DIVISION OF MINES AND GEOLOGY
TEMPERATURE LOG

LOCATION MORTON'S HOT SPRING WARM WELL (C-4)

DATE $2 / 24 / 82$

TEMPERATURE DEGREES CELSIUS

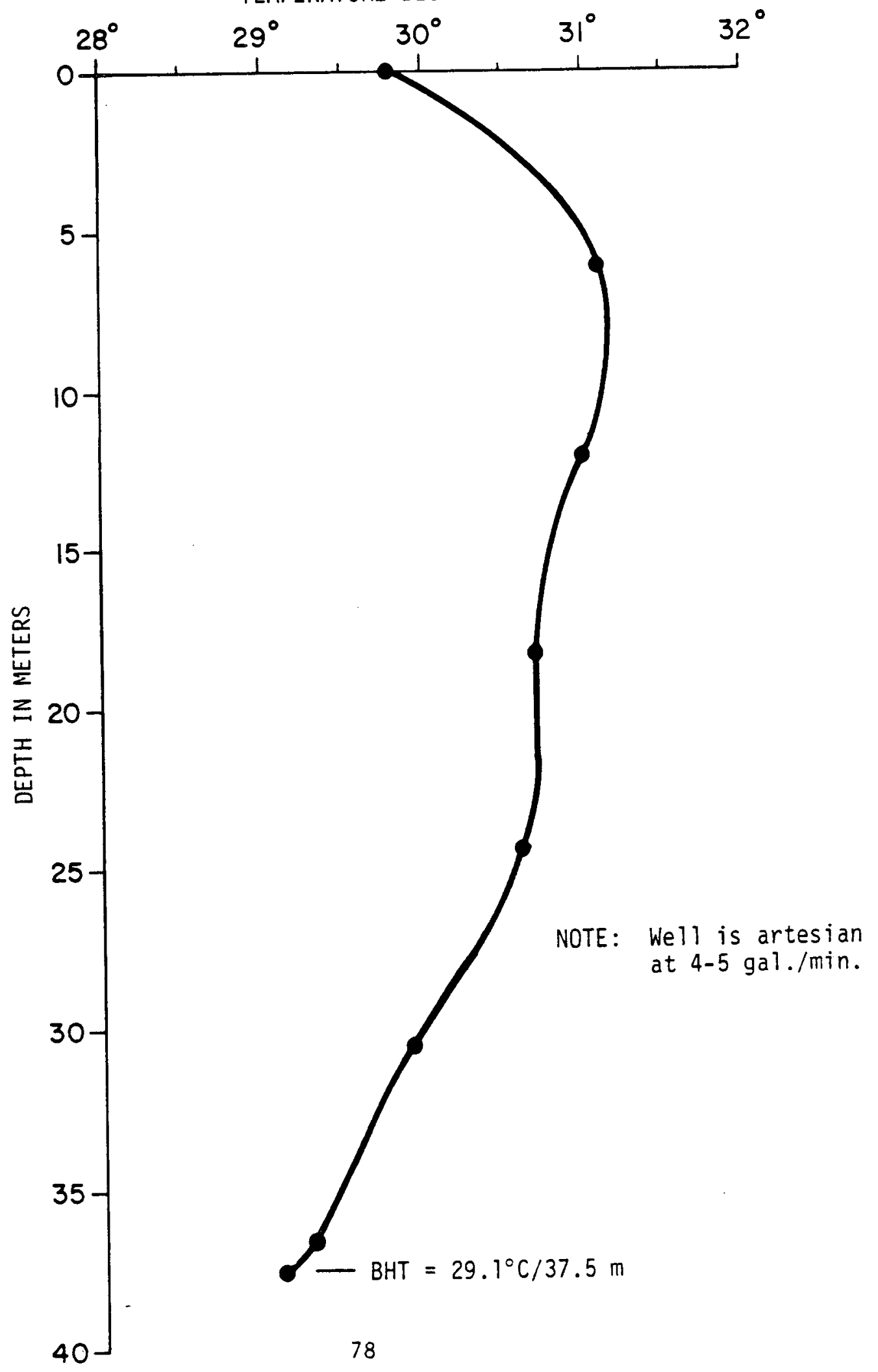


Figure 28.

\section{CALIFORNIA DIVISION OF MINES AND GEOLOGY \\ TEMPERATURE LOG}

\section{LOCATION SONOMA STATE HOSPITAL WARM WELL DATE 2/22/82}

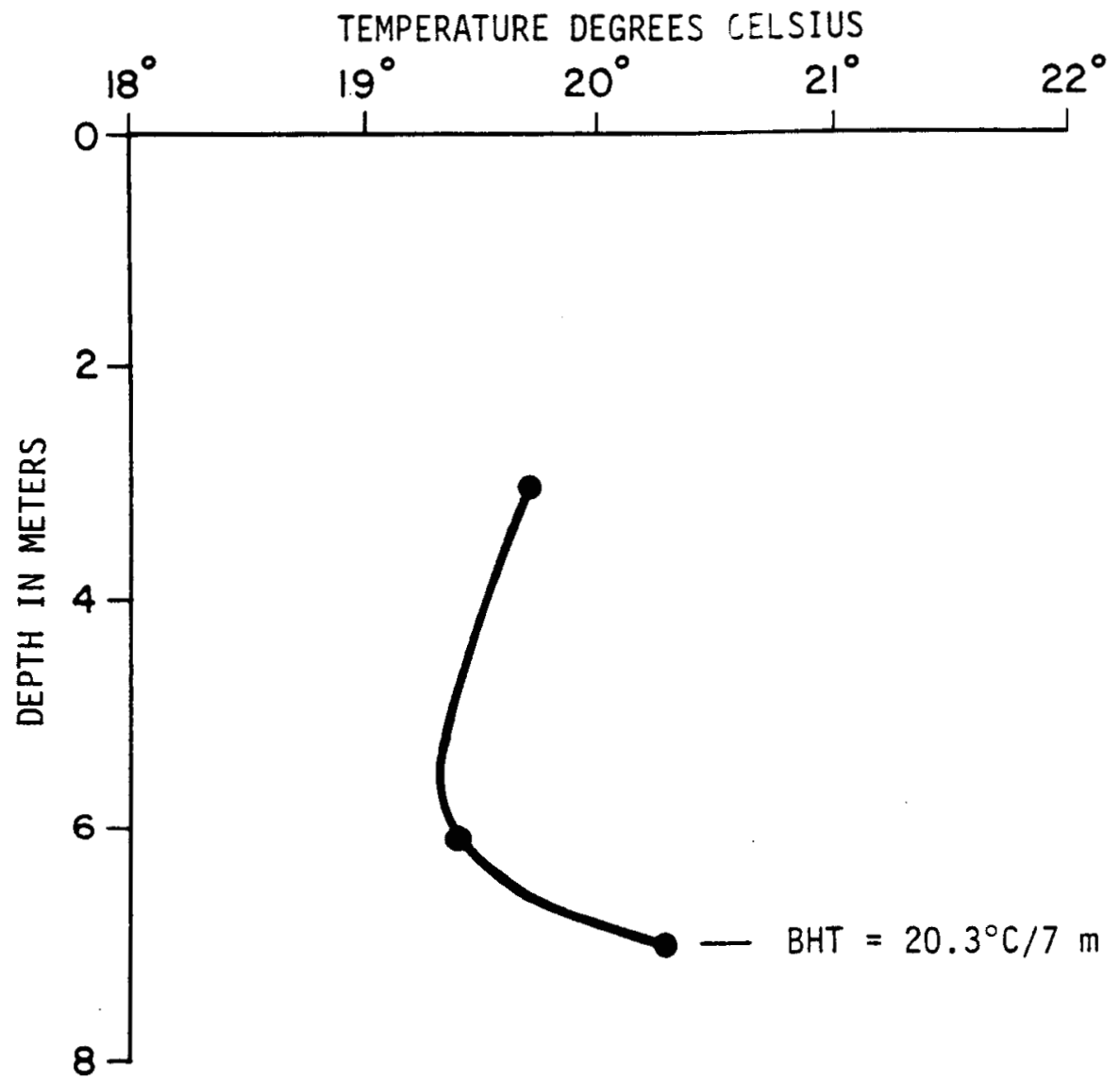


Figure 29.

\section{CALIFORNIA DIVISION OF MINES AND GEOLOGY \\ TEMPERATURE LOG}

LOCATION AGUA CALIENTE VILLA WARM WELL

DATE $4 / 6 / 82$

TEMPERATURE DEGREES CELSIUS

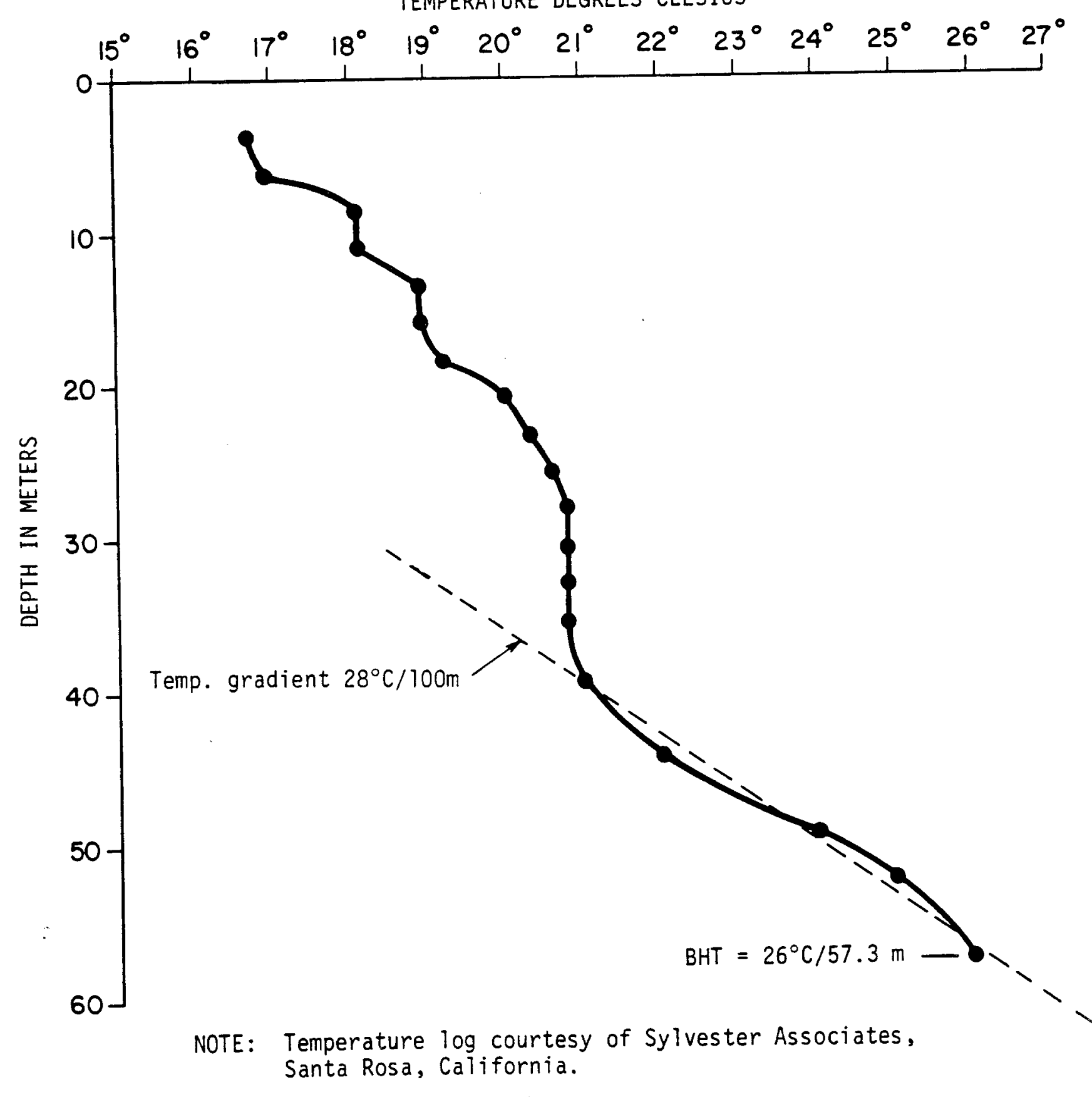


Figure 30 .

\section{CALIFORNIA DIVISION OF MINES AND GEOLOGY \\ TEMPERATURE LOG}

LOCATION BOYES HOT SPRING WELL NO. 2(?)

DATE UNKNOWN

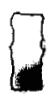

TEMPERATURE DEGREES CELSIUS

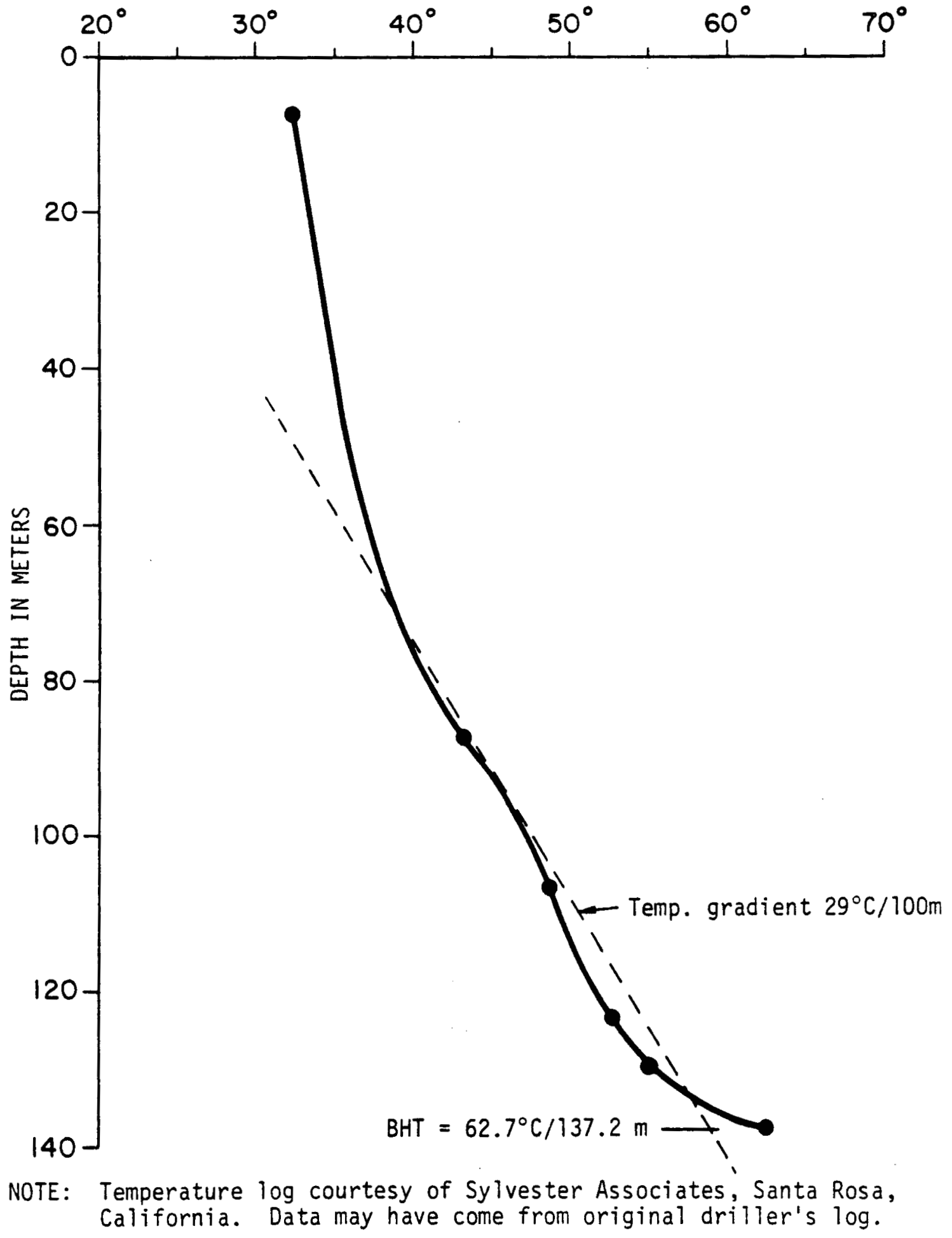


Figure 31.

CALIFORNIA DIVISION OF MINES AND GEOLOGY

TEMPERATURE LOG

LOCATION SALT RANCH WARM WELL

DATE APRIL 1982

TEMPERATURE DEGREES CELSIUS

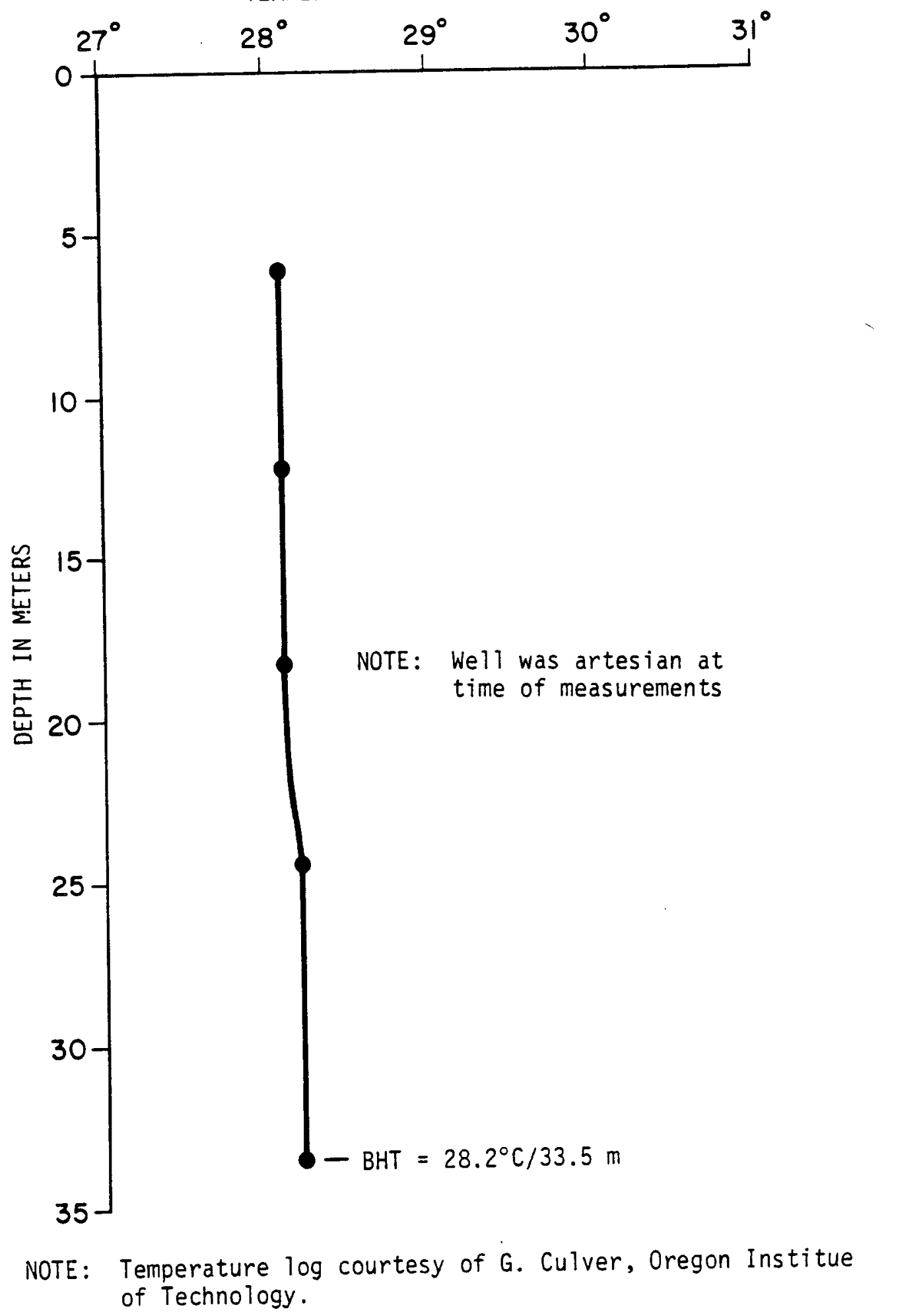


A straight line segment manually fit to the deepest five temperature measurements (in the same manner as Figure 29) yields a temperature gradient of $29^{\circ} \mathrm{C} / 100$ meters. This is very near the value obtained from Figure 29.

The "Salt Ranch warm well" was artesian at the time data were collected for the temperature curve of Figure 31. The temperature profile of Figure 31 is typical of an artesian well or a well that has heavy turbulence within its water column. The temperature remains relatively constant, in this case at approximately $28^{\circ} \mathrm{C}\left(82^{\circ} \mathrm{F}\right)$, throughout the column of water.

\section{Conclusions}

Direct temperature measurements of geothermal wells and springs provide some insight into the possible expected temperature of the resource at shallow to moderate well depths in the Sonoma Valley. The maximum temperature listed in Table 5 is $63^{\circ} \mathrm{C}$ $\left(145^{\circ} \mathrm{F}\right)$ at 137 meters (450 feet) for a well at Boyes Hot Springs.

The grouping of the majority of the "warmer" geothermal wells in a northwest trend along the east side of Sonoma Valley may indicate that the highest reservoir temperatures may be found in this area with greater depth.

Although only a few downhole temperature profiles were able to be collected and only two profiles were adequate to calculate temperature gradients, it is significant that the two gradients are nearly equivalent at $28^{\circ} \mathrm{C} / 100 \mathrm{~m}$ and $29^{\circ} \mathrm{C} / 100 \mathrm{~m}$ (Figures 29 and 30). If these gradients were to be constant with depth then $100^{\circ} \mathrm{C}\left(212^{\circ} \mathrm{F}\right)$ reservoir temperatures would be encountered at approximately 325 meters (1066 feet) at the Agua Caliente Villa site and 270 meters ( 885 feet) at the Boyes Hot Springs site. However, in reality such gradients seldom remain consistent with depth. 


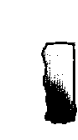

.

8

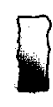

8 


\title{
CONCLUSIONS AND ASSESSMENT OF THE GEOTHERMAL RESOURCE
}

\author{
Introduction
}

Geothermal resources with the potential for useful development underlie the Sonoma Valley area, California. However, all of the temperatures observed in this study are less than $90^{\circ} \mathrm{C}\left(194^{\circ} \mathrm{F}\right)$. Therefore, the geothermal resources of Sonoma Valley can, at this time, only be classified as low-temperature $\left(20^{\circ}-90^{\circ} \mathrm{C}\right)$ geothermal resources. Such temperatures are not suited to large scale geothermal development or for electrical power generation. Low-temperature geothermal resources are suited to small direct use projects and usually can only be developed close to the point of origin. Thus, the geothermal resources of Sonoma Valley would be useful to local landowners, small business and agricultural projects, direct heating applications of single and multiple family housing, public buildings, etc. Figure 33 is a partial list of potential uses of low-temperature geothermal resources.

Surficial evidence of possible geothermal resources in the Sonoma Valley area have long been known. The earliest commercial development of geothermal resources was perhaps nearly 135 years ago at Boyes Hot Springs (then known as Agua Rica Springs). Geothermal fluids can still be produced at all the historically geothermal areas, although some locales which were originally reported as springs now produce warm water only from shallow to moderately deep wells. The Pliocene Sonoma Volcanics blanketing the area imply the presence of associated geothermal resources for several past thousands of millennia. This apparent longevity of the regional geothermal resources should be encouraging to potential users.

\section{Areal Distribution}

The size of a geothermal resource is not necessarily proportional to the areal distribution of surficial evidence, nevertheless, such a distribution is an invaluable resource parameter.

The major study area of this report was in the central and south central portions of Sonoma Valley. In this general area, 29 low-temperature geothermal wells or springs were located from either literature search or field surveys. There are probably more warm water wells and springs in this area than were "documented" in the preparation of this report. Therefore, the warm well locations plotted on Plate 1 may not be complete.

The majority of the geothermal surface manifestations (wells and/or springs) plotted on Plate 1 are found in an approximate $10 \mathrm{~km}(6.2 \mathrm{miles})$ long zone bounded on the east by the Mayacmas Mountains and on the west by the "east side" fault delineated from geophysical evidence. This zone is termed the "Most Likely Geothermal Production Zone" on Plate 1 and contains an area of approximately $5.4 \mathrm{~km} 2(2.1 \mathrm{mi} 2)$. The zone includes 52 percent of the total geothermal locations on the map. This northwest trending zone appears to be an elongated extension of the historic "warm water belt" that included the Agua Caliente Spring (Plate 1, Location No. C-40), Fetters Hot Springs (Plate 1, Location No. $(-41)$, and Boyes Hot Springs (Plate 1). The zone also generally coincides with the closed $100^{\circ} \mathrm{C}$ temperature contour in association with the "east side" fault on the $\mathrm{Na}-\mathrm{K}-\mathrm{Ca}(B=4 / 3)$ Geothermometry Map (Plate 8).

It must be strongly pointed out that there are apparently many water wells that do not have geothermal temperatures $\left(>20^{\circ} \mathrm{C}\right)$ located in this "production zone". No formal survey was made of "cool" wells and geothermal wells versus depth or distribution, but it appears many "cool" wells are of comparable depth to geothermal wells within the boundary limits. The implication is that the geothermal aquifers within the reservoir are highly localized and do not extend continuously under the valley. 
Two other features of the distribution of geothermal locations are evident on Plate 1. One is the close grouping, south of Kenwood, of well Location No. C-35, Morton's Warm Springs (Location No. C-4), and the old McEwan Ranch warm spring (Location No. $\mathrm{C}-5)$. The second feature is the linear, but not well defined, nor thwest alignment of the Salt Ranch warm well, well Location No. S-18, and well Location No. C-39 south of the City of Sonoma and along the eastern flank of the Sonoma Mountains.

\section{Depth of Resource}

The depth to an adequate geothermal resource is often the major criteria to economic feasibility of utilization of that resource. Historically, small geothermal springs discharged fluids at the surface in the Sonoma Valley area. Most have disappeared. Although, some like the old MCEwan Ranch spring still flow. Local accounts suggest the presence of a few small, probably seasonal, warm springs in the hills and canyons adjacent to the Sonoma Valley. The natural springs at Boyes Hot Springs appear to have "dried up" sometime after 1926.

The depths of the known geothermal wells included in the "Most Likely Geothermal Production Zone" of Plate 1 range from 50-177 $\mathrm{m}$ (165-581 feet) (Table 5) with an average of $92 \mathrm{~m}$ (301 feet). The exception is the Sonoma State Hospital warm well which is in reality a shallow hand dug cistern into an old spring. It is inferred that to be successful geothermal wells probably would have to be drilled to an average depth of at least (and greater than) $100 \mathrm{~m}$ (328 feet) in this "production zone".

The geological and geophysical data in this report may indicate that geothermal wells and springs are associated with warm water aquifers within units of the Sonoma Volcanics. If this data is generally applicable, then potential geothermal wells sited on, for example, alluvial strata of the Sonoma Valley floor should probably be programmed to be drilled to a depth to encounter the underlying volcanic strata. Unfortunately, the depth of the valley alluvium is not well documented, except along geophysical traverses, and must vary greatly depending upon subsurface structure throughout the valley. Esitmates were calculated for the depth to Sonoma Volcanics along geophysical traverse $\mathrm{H}-\mathrm{H}^{\prime}$ (Plate 3 and Figure 5) across the "east side" fault east of the Hanna Center. On the upthrown side of the fault (east side) the depth to the Sonoma Volcanics is approximately $76 \mathrm{~m}$ (250 feet). The "production zone" discussed above is primarily on the east side of this fault. The calculated depth is only $16 \mathrm{~m}$ ( 51 feet) shallower than the $92 \mathrm{~m}(30 \mathrm{l}$ feet) average depth of known geothermal wells in the "production zone". This suggests that the known geothermal wells in this area project through the alluvium and into the underlying Sonoma Volcanics strata.

The offset on the "east side" fault along traverse $\mathrm{H}-\mathrm{H}$ ' (Figure 5) was calculated at 76 $m$ (250 feet) also. Therefore, west of the "east side" fault a geothermal aquifer similar to that found to the east of the fault may possibly be found at this greater depth. However, the fault may behave as a water barrier trapping geothermal fluids on the east side of the fault.

One or more geothermal fluid-bearing aquifers may be relatively shallow in the vicinity of the old McEwan Ranch warm spring and Morton's Warm Springs (Plate 1, Location No. C-5 and C-4 respectively). The McEwan Ranch Spring currently has a surface discharge of approximately $5 \mathrm{gpm}$. The temperature log from Morton's Warm Springs (Figure 27) shows the warmest temperature zone to be from 5-12.5 meters (16-41 feet) in a 37.5 meter (123-foot) deep well. 
The depth to the geothermal resources under the Sonoma Valley appears to be highly variable probably depending on depth to volcanic strata underlying the valley alluvium, subsurface geologic structure and fabric, amount of recharge into the warm water reservoir systems, and the amount of fluids withdrawn from the reservoir system.

\section{Volume of Geothermal Resources}

Quanitative calculations of the volume of geothermal resources underlying the Sonoma Valley would be highly speculative because of the complexity of geothermal aquifer configuration, and in particular, the general lack of data from deeper and apparently hotter horizons. However, some general qualitative statements can be made.

The historic literature seldom indicates a flow rate of greater than $100 \mathrm{gpm}$ for any of the old natural warm springs or for most of the wells that produced warm water in the valley. Some were reported to be less than $10 \mathrm{gpm}$. Local accounts report a few modern water wells that produce volumes in the several 100's of gallons per minute of slightly warm water. However, the greatest percentage of these volumes are probably produced from fresh water aquifers and only incidentally mixed with fluids from minor warm water aquifers encountered when drilling.

Herbst (1982) assigned a highly variable specific yield of from $0-15$ percent for the Sonoma Volcanics. If, as data suggest, geothermal fluids in the Sonoma Valley are predominately produced from permeable units of the Sonoma Volcanics, then the highly variable specific yield suggests low or at the best highly variable volumes for geothermal aquifers.

Whatever the capacity of the geothermal reservoir under Sonoma Valley, the volume of geothermal fludis stored may not have changed much over time as Herbst (1982) says that the volume of the entire hydrological system of the valley has not changed much over time.

There is a lack of sufficient quantitative geothermal reservoir data, but the qualitative data that is available indicates that estimates of the volume of low-temperature geothermal production in the Sonoma Valley area should be kept very conservative. Adequate exploration drilling and subsequent well flow testing would greatly enhance the data needed to estimate the volume of geothermal resources underlying the Sonoma Valley area.

\section{Temperature of Geothermal Resources}

California Division of Mines and Geology (CDMG) measured geothermal surface discharge temperatures from $20^{\circ}-35^{\circ} \mathrm{C}\left(68^{\circ}-95^{\circ} \mathrm{F}\right)$ in wells and springs in the Sonoma Valley area (Table 5). The mixing factor of fluids from cool and warm water aquifers in these wells is not known. Historically, the most often reported maximum temperature was approximately $44^{\circ} \mathrm{C}\left(112^{\circ} \mathrm{F}\right)$ at Boyes Hot Springs. The greatest recorded downhole temperature in the valley is the unconfirmed $62.7^{\circ} \mathrm{C}\left(145^{\circ} \mathrm{F}\right)$ at 137.2 meters $(450$ feet $)$ at Boyes Hot Springs.

The average values of three of the geothermometer algorithms (Table 4) for wells or springs with surface temperatures greater than or equal to $20^{\circ} \mathrm{C}\left(68^{\circ} \mathrm{F}\right)$ range from $52^{\circ}-77^{\circ}$ $\left(126^{\circ}-171^{\circ} \mathrm{F}\right)$. Although, one or two of the other geothermometer indicators show reservoir temperatures higher than this, these three are in relatively close agreement. Therefore, the reservoir temperature may be in this range. 
Two temperature gradients (Figures 29 and 30$)$ predict $100^{\circ} \mathrm{C}\left(212^{\circ} \mathrm{F}\right.$ ) water at a depth of 325 meters (1066 feet) at the Agua Caliente Villa site and 270 meters ( 885 feet) at the Boyes Hot Springs site. However, little credence should be given to these calculations since one temperature $\log$ is unconfirmed and gradients from shallow wells seldom remain constant with depth.

Deeper exploration drilling and sampling from distinct geothermal aquifers should provide the data needed to confirm the reservoir temperatures of geothermal resources in the Sonoma Valley area.

\section{Reservoir Model}

The low-temperature geothermal resources in the Sonoma Valley area are characteristic of liquid-dominated hydrothermal convection systems. The common components of such systems include a heat source, a transmitting fluid, sufficient permeability to allow fluid movement, sufficient porosity to provide an adequate reservoir volume, and sometimes a cap rock overlying the reservoir to insulate and aid in the accumulation and storage of the heat energy. Gravity is the mechanism that transports cool meteoric water downward through the system while convective circulation of the less dense hotter fluids is the driving mechanism that transports heat energy from depth to reservoirs near the earth's surface. Hydrothermal convection systems are most likely recognizable in areas of extensive faulting where geothermal springs may develop. Such systems are usually controlled by several intersecting geologic structures.

It should be pointed out that many techniques employed in this study do not directly "see" or physically measure the components of a particular geothermal reservoir. For example, in this report, gravity and magnetic surveys were able to define subsurface structural configurations that, when compared to data from geothermal wells and springs, could then be interpreted as integral features of the geothermal reservoir. Only by analyzing all of the data from all of the geotechniques applied to this study (whether they were supportive or contradictory) could a model of the hydrothermal system in the Sonoma Valley area be devised.

Figure 32 is an east-west oriented diagrammatic cross-section of the descending and ascending cycles of the hydrothermal convection systems in the Sonoma Valley area. Meteoric water (rain, snow, etc.) enters the systems through permeable units or fracture zones in the surrounding mountains to the east and west of the valley. It is likely some recharge occurs from surface water that may descend along some, or portions of some, fault zones in the valley. The fluids are heated at depth from the earth's natural heat gradient. Heated fluids then ascend along "paths of least resistance" (faults, fractures, geologic contacts, ect. - in Figure 32 represented by faults on the east and west sides of the valley) into overlying permeable aquifers (thought mostly to be within units of the Sonoma Volcanics) forming a complex geothermal reservoir system. This forms a geothermal reservoir of discrete and discontinuous warm water bearing aquifers charged by "plumes" of ascending geothermal fluids. The discontinuity of the geothermal aquifers is reflected in the highly variable specific yield ( $0-15$ percent) of units within the Sonoma Volcanics, and is partly the result of volcanic depositional facies changes, folding, and faulting.

The impermeable cap rocks overlying geothermal aquifers in the reservoir system of the Sonoma Valley probably include basaltic and andesitic volcanic flow rocks and probably clay strata. 


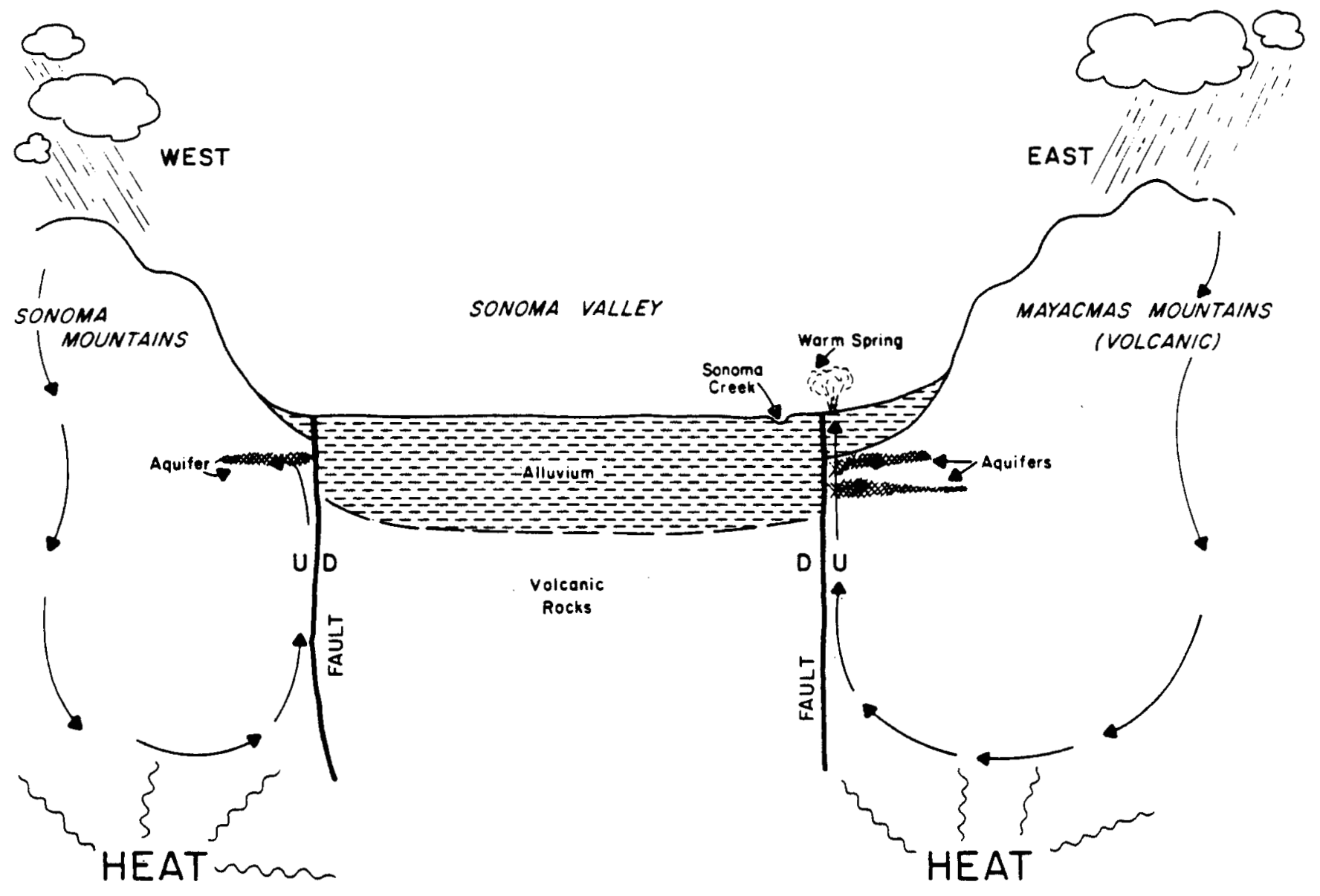

Figure 32. Diagrammatic cross-section of the low-temperature geothermal reservoir in the Sonoma Valley area, California. By L.G. Youngs, 1982, CDMG. 
The most easily recognizable geothermal "plume" is in the area marked as "The Most Likely Geothermal Production Zone" on Plate I. It is thought that geothermal fluids ascend the "east side" fault into permeable aquifers under the Sonoma Valley. In the past, these fluids escaped at the surface at or near the trace of the "east side" fault forming many of the old natural warm springs in this area.

\section{Conclusions and Recommendations}

The low-temperature geothermal resources underlying the Sonoma Valley have good potential for local direct use projects (Figure 33). Historically the valley's geothermal resources have remained relatively constant in temperature and volume, but with some warm water tables lowering in heavily used areas. The warmest fluids appear to be in aquifers at the Boyes Hot Springs site located on the "east side" fault alignment. The location of this fault was first determined from geophysical investigations. A higher boron and sodium concentration anomaly in well waters, a high temperature anomaly calculated using the $\mathrm{Na}-\mathrm{K}-\mathrm{Ca} \quad(B=4 / 3)$ geothermometer, and an alignment of known geothermal wells and springs approximately coincide with the "east side" fault trace. The fault appears to act as a conduit for upward migration of warmed fluids in the liquid-dominated hydrothermal convection system of Sonoma Valley. Along the east side of this fault is a $10 \mathrm{~km}$ (6.2 mile) long zone (Plate 1) where future low-temperature development from moderately shallow drilled wells (100 meter - 328 feet) has the greatest potential for success. Additionally, there appears to be a good possibility that by drilling deeper in this zone ( 152 meters - 500 feet) and using a carefully designed casing program, fluids with temperatures in the $52^{\circ}-77^{\circ} \mathrm{C}$ range may be recovered. The Morton's Warm Springs area near Kenwood and the western edge of the Sonoma Valley south of the City of Sonoma at the base of the Sonoma Mountains may be two other favorable zones for low-temperature geothermal development. However, further overall geoscientific investigation is needed to better assess the geothermal potential in each of these areas.

Geophysical application of gravity and magnetic measurement techniques supported by some seismic refraction surveys was clearly able to define the faulting fabric underlying the Sonoma Valley, as well as in some cases, delineate volcanic rocks buried under sediments of the valley. Major geophysical anomalies were uncovered by these techniques and future investigations should include pursuing the extent and cause of these anomalies along their north and northwestward projections from the study area. Unfortunately, electrical resistivity techniques proved to be of only minor value in understanding the geothermal resources of the valley. The low geothermal fluids temperature, relatively low mineral content of the fluids, and the presence of a large volume of electrically conductive clay units in the valley sediments greatly hampered electrical resistivity analyses. Probably shallow to moderately deep electrical resistivity measurements would be of only very localized value in future geothermal resource investigations in the Sonoma Valley area. Results of geochemical sampling of springs and wells proved helpful in supporting the existence of the "east side" fault and in determining that a probable geothermal "plume" exists along at least a portion of its alignment. Perhaps detailed and localized geochemical water sampling in some of the potential geothermal resource zones of the valley would yield significant results rather than a large valley-wide scattered sampling program. The geothermometry data in this report should be considered questionable due in part to mixing of fresh water and geothermal fluids in wells perforated for maximum overall water production. It would be advantageous in future investigations to obtain water samples solely derived from warm water aquifers for analyses and subsequent geothermometry calculation. The subsurface geologic record for 


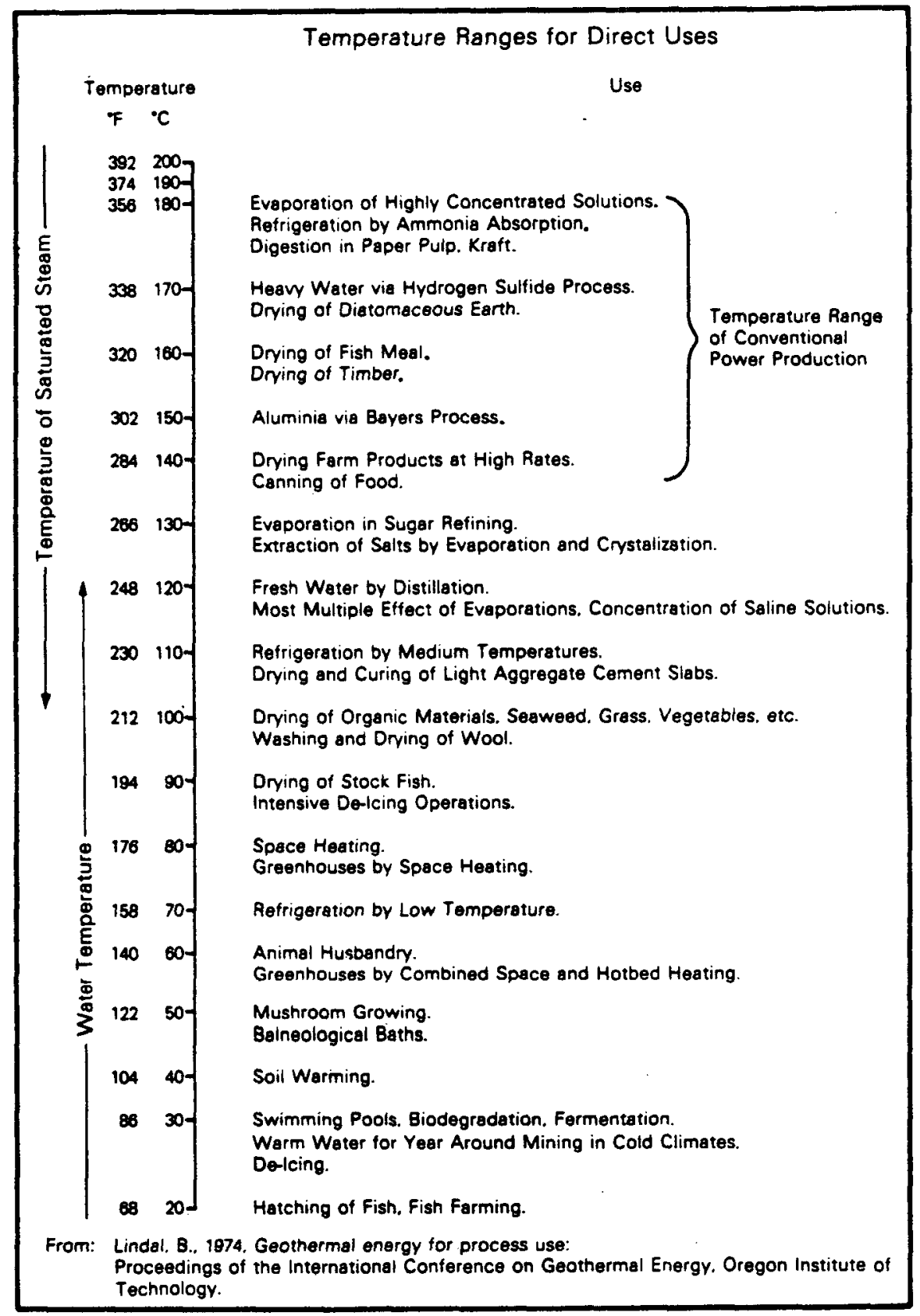

Figure 33. Temperature ranges of some possible geothermal direct uses. 
Sonoma Valley is scant. The only downhole data available appears to be from water well driller's logs. Future geothermal investigations of the Sonoma Valley area would be greatly benefited if detailed downhole geologic data could be obtained. There are an insufficient number of downhole temperature profiles presented in this report to be of much value in predicting geothermal temperatures at depth in the Sonoma Valley. It is recommended that future investigations include the acquisition of more downhole temperature logs. A shallow-hole temperature probe survey laid out in grid format may greatly refine the heat distribution pattern in some of the potential geothermal resource zones described above.

The understanding of a geothermal resource improves with the acquisition of more and better defined data. Therefore, it is expected that some material and some conclusions concerning the low-temperature resources of the Sonoma Valley area presented in this report will be modified in the future. Certainly, subsurface data derived from the geothermal exploration well (drilling began in July, 1982) on the Sonoma State Hospital grounds and from a proposed $244 \mathrm{~m}$ (800-foot) deep geothermal production well to be drilled in January, 1983 at the old Boyes Hot Springs grounds will add greatly to the understanding of the character and nature of the geothermal resources in the Sonoma Valley area. 


\section{REFERENCES CITED}

Anonymous, 1897, Illustrated Atlas of Sonoma County, California: Reynolds and Proctor, Santa Rosa, 64 p.

Axelrod, D.I., 1950, A Sonoma florule from Napa, California: Carnegie Inst. Washington Pub. 590, p. 23-71.

Barnes, I., 1970, Metamorphic waters from the Pacific Tectonic belt of the West Coast of the United States: Science, v. 168, no. 3934, p. 973-975.

Beard, Y.S., 1979, The Wappo - A report: Makli Museum Press, Banning, California, $88 \mathrm{p}$.

Berkstresser, C.F.. Jr., 1968, Data for springs in the northern Coast Ranges and Klamath Mountains of California: U.S. Geological Survey, Open-File Report, 49 p.

Blaydes, P.E., 1981, Direct use geothermal resources map series, maps no. XXI, no. XXII, and no. XXIIl: G.R.I.P.S. Commission, Santa Rosa, California, Scale 1:62,500.

Bowen, R., 1979, Geothermal Resources: Halsted Press Division, John Wiley and Sons, New York, 243 p.

Bradley, W.W., 1915, Sonoma County - mineral water: California State Mining Bureau, Report XIV of the State Mineralogist, p. 334-341.

California Division of Oil and Gas, 1981, Historical records help to assess geothermal resources: Geothermal Hot Line, v. 11, no. 1, p. 4-5.

Chapman, R.H., 1966. The California Division of Mines and Geology gravity base station network: California Division of Mines and Geology Special Report 90, 49 p.

Chapman, R.H., and Bishop, C.C., 1974, Bouguer gravity map of California, Santa Rosa sheet: California Division of Mines and Geology, scale 1:250,000, 7 p. text.

Chapman, R.H., and Chase, G.W., 1982, Geophysical study of the Sonoma State Hospital area geothermal prospect, Sonoma County, California: California Division of Mines and Geology, report for the California Energy Commission, Interagency Agreement No. 500-80-102, 36 p.

Clark, W.O., 1919, Ground water in Green Valley, Napa Valley, and Sonoma Valley: U.S. Geological Survey, Open-File Report.

Cook, F.S., 197? Historic legends of Sonoma County: California Traveler, Inc., Volcano, CaITifornia, 48 p.

Crawford, J.J., 1894, Mineral springs - Sonoma County: California State Mining Bureau, Report XII of the State Mineralogist, p. 347.

Crawford, J.J., 1896, Mineral springs - Sonoma County: California State Mining Bureau, Report XIII of the State Mineralogist, p. 521-522.

Culver, G., 1982, Personal communication: Oregon Institute of Technology, Klamath Falls, Oregon. 
Dickerson, R.E., 1922, Tertiary and Quarternary history of the Petaluma, Point Reyes and Santa Rosa Quadrangles: Proceedings of the California Academy of Sciences, Fourth Series, v. XI, no. 19, p. 527-601.

Evernden, J.F., and James, G.T., 1964, Potassium-argon dates and the Tertiary floras of North America: Am. Jour. Sci., v. 262, p. 945-974.

Finley, E.L., 1937, History of Sonoma County, California: The Press Democrat Publishing Company, Santa Rosa, California, 453 p.

Ford, R.S., 1975, Evaluation of ground water resources, Sonoma County geologic and hydrologic data: California Department of Water Resources, Bulletin $118-4$, v. 1, 177 p. .

Fournier, R.O., 1977, Chemical geothermometers and mixing models for geothermal systems: Geothermics, v. 5, p. 41-50.

Fournier, R.O., and Potter II, R.W., 1978, A magnesium correction for the Na-K-Ca geothermometers: Geochimica et Cosmochimica Acta, v. 43, p. 1543-1550.

Fox, K.F., Jr., Sims, J.D., Bartow, J.A., and Helley, E.J., 1973, Preliminary geologic map of eastern Sonoma County and western Napa County. California: U.S. Geological Survey Miscellaneous Field Studies Map MF-483, scale 1:62,500.

Gregory, T., 1911, History of Sonoma County, California: Historic Record Cumpany, Los Angeles, California, p. 148 and 298.

Haines, D.N., and Campbell, D.L., 1979, Texas Instruments model 59 hand-calculator program to calculate gravity anomaly over 2-D prisms of as many as 18 vertices: U.S. Geological Survey Open File-Report 79-1620, 12 p.

Haines, D.N., and Campbell, D.L., 1980, Texas Instruments model 59 hand-calculator program to calculate theoretical Wenner and Schlumberger vertical electric soundings over a structure of up to 10 horizontal layers: U.S. Geological Survey Open-File Report 80-190, 15 p.

Herbst, C.M., 1982, Evaluation of ground water resources, Sonoma County: Department of Water Resources, Bulletin 118-4, v. 4, 78 p.

Kunkel, F., and Upson, J.E., 1960, Geology and ground water in Napa and Sonoma Valleys, Napa and Sonoma Counties, California: U.S. Geological Survey Water Supply Paper 1495, 252 p.

Laizure, C.M., 1926, Sonoma County - Mineral water: California State Mining Bureau, Report XXII of the State Mineralogist, p. 339-343.

Leivas, E. Martin, R.C., Higgins, C.T., and Bezore, S.P., 1981, Reconnaissance geothermal resource assessment of 40 sites in California - Part of the third year report. 1980-81, of the U.S. Department of Energy - California State-Coupled Program for reservoir assessment and confirmation: California Division of Mines and Geology, Report for U.S. Department of Energy, Contract No. DE-FG3-90SF10855, 243 p.

Lynch, J.F., date unknown, Captain Boyes memorable discovery - a flowing well of hot water at 70 feet: Unpublished manuscript, 3 p. 
Mankinen, E.A., 1972, Paleomagnetism and potassium-argon ages of the Sonoma Volcanics, California: Geol. Soc. of America Bull., v. 83, p. 2063-2072.

Nettleton, L.L., 1976, Gravity and magnetics in oil prospecting: McGraw Hill Book Company, New York, 464 p.

Orellana, E., and Mooney, H.M., 1966, Master tables and curves for vertical electrical soundings over layered structures: Interciencia, Madrid, 34 p.

Osmont, V.C., 1904, A geological section of the Coast Ranges north of the Bay of San Francisco: University of California Publications, Bulletin of the Department of Geology, v. 4, no. 3, p. 39-87.

Plouff, Donald, 1977, Preliminary documentation for FORTRAN program to compute gravity terrain corrections based on topography digitized on a geographic grid: U.S. Geological Survey Open-File Report 77-535, 45 p.

Rapport, A., 1982, FORTRAN program to compute chemical geothermometers for geothermal fluids: U.S. Geological Survey, Open-File Report 82-308, 25 p.

Real, C.R., Toppozada, T.R., and Parke, D.L., 1978, Earthquake catalog of California, January 1,1900 - December 31, 1974: California Division of Mines and Geology, Special Publication 52, 15 p.

Rijkswaterstaat, 1969, Standard graphs for resistivity prospecting: European Association of Exploration Geophysicists, 4 p. and unnumbered tables.

Sickles, J.M., 1973, Geology and geologic hazards of the Kenwood-Glen Ellen area, eastern Sonoma County, California: Unpublished Masters thesis, University of California, Davis, California.

Sylvester Associates, 1982, Personal communication: Santa Rosa, California.

Toppozada, T.R., Real, C.R., Bezore, S.P., and Parke, D.L., 1980, Preparation of isoseismal maps and summaries of reported effects for pre-1900 California earthquakes: California Division of Mines and Geology. Open-File Report 80-15SAC, Annual Technical Report to the U.S. Geological Survey, Grant No. 14-08-001-18243, 78 p.

U.S. Geological Survey, 1974a, Aeromagnetic map of parts of the San Jose, Santa Rosa, and Sacramento $1^{\circ} \times 2^{\circ}$ quadrangles, California: U.S. Geological Survey Open-File Report 74-80, scale 1:125,000.

U.S. Geological Survey, 1974b, Aeromagnetic map of parts of the Santa Rosa and San Francisco $1^{\circ} \times 2^{\circ}$ quadrangles, California: U.S. Geological Survey Open-File Report 74-81, scale 1:125,000.

Warning, G.A., 1915, Springs of California: U.S. Geological Survey, Water Supply Paper 338,410 p.

Watts, W.L., 1892, Sonoma County - Springs and wells yielding inflammable gas: California State Mining Bureau, Report XI of the State Mineralogist, p. 458-459.

Weaver, C.E., 1949, Geology of the Coast Ranges immediately north of the San Francisco Bay Region, California: G.S.A. Mem. 35, 242 p. 


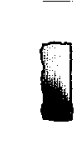

8

.

.

D

.

$\triangle$

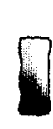

.

I

8

$B$

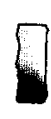

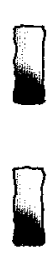

$\Delta$

. 


\section{SELECTED REFERENCES FOR THE SONOMA VALLEY \\ LOW-TEMPERATURE GEOTHERMAL RESOURCE AREA, CALIFORNIA}

By

Stephen P. Bezore

1982

Armstrong, C.F., 1974, Unpublished active fault mapping in parts of the Glenn Ellen, Petaluma River, and Sears Point 7 1/2-minute quadranges, California: California Division of Mines and Geology.

Axelrod, D.I., 1944, The Sonoma Flora in Chaney, R.W., Ed., Pliocene floras of California and Oregon: Carnegie Inst. Washington Pub. 553, p. 167-206.

Barnes, I., Irwin, W.P., and Gibson, H.A., 1975, Geologic map showing springs $r$ ich in carbon dioxide or chloride in California, U.S. Geologic Survey, Water Resources, Open File Map.

Barnes, I., and O'Neil, J.R., 1971, Calcium-magnesium carbonate solid solutions from Holocene conglomerate cements and travertines in the Coastal Range of California: Geochimica et Cosmochimica Acta, v. 35, no. 7, p. 699-718.

Barnes, I., and O'Neil, J.R., 1969. The relationship between fluids in some fresh alpine-type ultramafics and possible modern serpentinzation, western United States: Geological Society of America Bulletin, v. 80, no. 10, p. 1947-1960.

Bedrossian, T.L., 1971, Fossils of the 'Merced' Formation, Sebastopol Region: California Geology, California Division of Mines and Geology: v. 27, no. 8, p. 175-182.

1969, Paleoecological evaluation of the 'Merced' Formation, Sonoma County, California: University of California, unpublished.

Berkstresser, C.F., Jr., 1968, Data for springs in the northern Coast Ranges and Klamath Mountains of California: U.S. Geological Survey, Water Resources Division, Open File Report, 49 pages.

Blake, M.C., Jr., Bartow, J.A., Frizzell, V.A., Jr., Schlocker, J., Sorg, D., Wentworth, C.M., and Wright, R.H., 1974, Preliminary geologic map of Marin and San Francisco Counties and parts of Alameda, Contra Costa, and Sonoma Counties, California: U.S. Geological Survey and U.S. Department of Housing and Urban Development, Basic Data Contribution 64, San Francisco Bay Region Environment and Resources Planning Study.

Blake, M.C., Jr., Smith, J.T., Wentworth, C.M., and Wright, R.H., 1971, Preliminary geologic map of western Sonoma County and northernmost Marin County, California: U.S. Geological Survey and U.S. Department of Housing and Urban Development, Basic Data Contribution 12, San Francisco Bay Region Environment and Resources Planning Study.

Blake, M.C., Jr., Zietz, I., and Daniels, D.L., 1978, Aeromagnetic and generalized geologic map of parts of central California: U.S. Geological Survey, Geophysical Investigations, Map GP-918.

Bradley, W.W., 1915, Sonoma County - mineral water: California State Mining Bureau, Report XIV of the State Mineralogist, p. 334.-341. 
Burke, D.B., et al., (In Press), Geologic map of the Flatland Deposits of the northwestern part of the San Francisco Bay Region: U.S. Geological Survey, Professional Paper 943.

Cady, J., 1975. Magnetic and gravity anomalies in the Great Valley and western Sierra Nevada metamorphic belt, California: Geological Society of America, Special Paper 168, 56 p.

California Division of Oil and Gas, 1975, Descriptions of northern California low-temperature Geothermal Resource Areas: California Division of Oil and Gas. Report Number TR 13.

Cardwell, G.T., 1958, Geology and ground water in the Santa Rosa and Petalum Valley areas, Sonoma County, California: U.S. Geological Survey, Water Supply Paper 1427,273 p.

Chapman, R.H., and Bishop, C.C., 1975, Bouguer gravity map of California, Santa Rosa Sheet: California Division of Mines and Geology.

Chapman, R.H., and Bishop, C.C., 1974, Gravity map of California, Santa Rosa Sheet: California Division of Mines and Geology.

Christensen, M.N., 1966, Quaternary of the California Coast Ranges in Geology of northern California: Chapter VI, San Francisco, California, p. 305-313.

Crawford, J.J., 1896, Mineral springs - Sonoma County: California State Mining Bureau, Report XIII of the State Mineralogist, p. 521-522.

Crawford, J.J., 1894, Mineral springs - Sonoma County: California State Mining Bureau, Report XII of the State Mineralogist, p. 347.

Dickerson, R.E., 1922, Tertiary and Quarternary history of the Petaluma, Point Reyes and Santa Rosa Quadrangles: Proceedings of the California Academy of Sciences, Fourth Series, v. XI, no. 19, p. 527-601.

Ford, R.S., 1975, Evaluation of ground water resources; Sonoma County: California Department of Water Resources, Bulletin 118-4, v. 1, 177 p.

Fox, K.F., Jr., Sims, J.D., Bartow, J.A., and Helley, E.J., 1973, Preliminary geologic map of eastern Sonoma County and western Napa County, California: U.S. Geological Survey and U.S. Department of Housing and Urban Development, Basic Data Contribution 56, San Francisco Bay Region Environment and Resources Planning Study.

G.R.I.P.S. Commission, 1981, Direct use geothermal Resources Map Series, Map No's XX and XXI.

Hauge, C., Kramer, C., Berkland, J., and Matthews, R., 1972, Field trip log: in Moores, Eldridge, J., and Matthews, R.A., eds., Geologic guide to the nor thern Coast Ranges--Lake Mendocino, and Sonoma Counties, California, Annual Field Trip Guide Book: Geological Society of Sacramento, p. 111-132.

Herbst, C.M., 1982, Evaluation of ground water resources - Sonoma County: Department of Water Resources, Bulletin 118-4, v. 4, 78 p. 
Herd, D.G., and Halley, E.J., 1976, Faults wtih Quaternary displacement northwestern San Francisco Bay Region, California: U.S. Geological Survey. Miscellaneous Field Studies Map MF-818.

Honke, M.T., Jr., and Ver Planck, W.E., Jr., 1950, Mines and mineral resources of Sonoma County, California: California Division of Mines and Geology, Journal of Mines and Geology, v. 46, no. 1.

Huffman, M.E., Armstrong, C.F., 1980, Geology for planning in Sonoma County: California Division of Mines and Geology Special Report 120, 31 p.

Jennings, C.W., and Hart, E.W., 1956, Exploratory wells drilled outside of oil and gas fields in California to December 31, 1953: California Division of Mines and Geology Special Report 45, 104 p.

Koenig, J.B., 1963, Santa Rosa Sheet: California Division of Mines and Geology, Geologic Map of California.

Kunkel, F., and Upson, J.E., 1960, Geology and ground water in Napa and Sonoma Valleys, Napa and Sonoma Counties, California: U.S. Geological Survey Water Supply Paper 1495, 252 p.

Laizure, C.M., 1926, Sonoma County - Mineral water: California State Mining Bureau, Report XXII of the State Mineralogist, p. 339-343.

Leivas, E., Martin, R.C., Higgins, C.T., and Bezore, S.P., 1981, Reconnaissance geothermal resource assessment of 40 sites in California - Part of the third year report, 1980-81, of the U.S. Department of Energy - California State-Coupled Program for reservoir assessment and confirmation: California Division of Mines and Geology, Report for U.S. Department of Energy, Contract No. DE-FG3-90SF 10855, 243 p.

Lynch, J.F., date unknown, Captain Boyes memorable discovery - a flowing well of hot water at 70 feet: Unpublished manuscript, 3 p.

Mankinen, E.A., 1972, Paleomagnetism and potassium-argon ages of the Sonoma Volcanics, California: G.S.A. Bulletin, v. 83, p. 2063-2072.

Miller, V.C. 1972, Soil Survey of Sonoma County: U.S. Department of Agriculture, Soil Conservation Service.

Morse, R.R., and Bailey, T.L., 1935, Geological observations in the Petaluma District, California: G.S.A. Bulletin, v. 46, p. 1437-1456.

Reed, J.J., 1975, Exploration and development of geothermal resources in Lake, Mendocino, and Sonoma Counties, California: California Division of Oil and Gas.

Sickles, J.M., 1973. Geology and geologic hazards of the Kenwood-Glen Ellen area, eastern Sonoma County. California: Unpublished Masters thesis, University of California, Davis, California.

U.S. Geological Survey, 1974, Aeromagnetic map of parts of the San Jose, Santa Rosa and Sacramento $1^{\circ} \times 2^{\circ}$ quadrangles, California: U.S. Geological Survey Open File Report 74-80. 
U.S. Geological Survey, 1974, Aeromagnetic map of parts of the Santa Rosa and San Francisco $1^{\circ} \times 2^{\circ}$ quadrangles, California: U.S. Geological Survey Open File Report 74-81.

U.S. Geological Survey, 1974, Aeromagnetic map of the northwest portion of the San Francisco Bay Region, California: U.S. Geological Survey Open File Report 76-618.

Waring, G.A., 1915, Springs of California: U.S. Geological Survey, Water Supply Paper 338,410 p.

Watts, W.L., 1892, Sonoma County - Springs and wells yielding inflammable gas: California State Mining Bureau, Report XI of the State Mineralogist, p. 458-459.

Weaver, C.E., 1949, Geology of the Coast Ranges immediately north of the San Francisco Bay Region, California: G.S.A. Mem. 35, 242 p.

Weaver, C.E., 1949, Geology and mineral deposits of an area north of San Francisco Bay: California Division of Mines and Geology, Bulletin 149.

Zietz, I., Bateman, P.C., Case, J.E., Crittenden, M.D., Jr., Griscom, A., King, E.R., Roberts, R.J., and Lorentzen, G.R., 1969, Aeromagnetic investigations of crustal structure for a strip across the western United States: Geological Society of America, Bulletin, v. 80, no. 9, p. 1703-1714. 


\title{
CALIFORNIA DIVISION OF MINES AND GEOLOGY GEOTHERMAL PUBLICATIONS
}

\author{
Generated in response to the U.S. Department of Energy \\ California State-Coupled Program for Reservoir \\ Assessment and Confirmation
}

$$
1978-1982
$$

Campion, L.F., Chapman, R.H., and Chase, G.W., Publication in 1982, Resource
investigation of low- and moderate-temperature geothermal areas in Paso Robles,
California - Part of the fourth year report, 1981-1982, of the U.S. Department of
Energy - California State-Coupled Program for reversoir assessment and confirmation:
California Division of Mines and Geology, Open-File Report Report for U.S.
Department of Energy, Contract No. DE-FG03-81SF10855, P. Repar.

"The report presents the data and results of a detailed scientific geothermal resource investigation of the Paso Robles area, California. Geothermal historical development, geology, geochemistry, hydrology, geophysical surveys, temperature measurements, and geothermal reservoir characteristics are addressed in the report."

Chapman, R.H., Chase, G.W., and Youngs, L.G., 1980, Geophysical survey, Paso Robles Geothermal Area, California - Part of the resource assessment of low- and moderate-temperature geothermal resource areas in California - Part of the second year report, 1979-80 of the U.S. Department of Energy - California State-Coupled Program for reservoir assessment and confirmation: California Division of Mines and Geology, 43 p.

"The report details an aeromagnetic, ground magnetic, and gravity survey conducted at the Paso Robles geothermal area. Interpretations of data are presented. A general overview of the Paso Robles geothermal area, including geology, history, hydrology. geochemistry, and geothermal activity, is included in the report."

Higgins, C.T., Chapman, R.H., and Chase, G.W., Publication in 1982, Geothermal resources of the Bridgeport-Bodie Hills regions, California - Part of the fourth year, 1981-82, of the U.S. Department of Energy - California State-Coupled Program for reservoir assessment and confirmation: California Division of Mines and Geology. Open-File Report_Report for U.S. Department of Energy, Contract No. DE-FG03-81SF10855. P.

"The report summarizes detailed geological, geochemical, and geophysical investigations of the area immediately southeast of Bridgeport as well as a regional evaluation of the Bodie Hills. The results of the investigations are used to speculate on the source of the thermal water and the nature of the area's source of heat."

Higgins, C.T., 1980, Geothermal resources of California: California Division of Mines and Geology, Geologic Data Map Series, Map no. 4, scale 1:750,000. 
"A $41 / 2$ by 5 foot, 5-color map of California with more than 600 geothermal wells and springs located. In addition to high-temperature geothermal resources that can be used to generate electricity, the map shows geothermal resources from which energy in the form of low- and moderate-temperature $\left(70^{\circ}-150^{\circ} \mathrm{F}\right)$ groundwater may be tapped for direct heat applications."

Leivas, E., and Bacon, C.F., Publication in 1982, Reconnaissance geothermal resource assessment of another 40 sites in California - Part of the fourth year, 1981-82, of the U.S. Department of Energy - California State-Coupled Program for reservoir assessment and confirmation: California Division of Mines and Geology, Open-File Report Report for U.S. Department of Energy, Contract No. De-FG03-8ISF10855. p.

"The report presents geological, geochemical, and historical data for another 40 low-temperature geothermal sites located throughout California."

Leivas, E., Martin, R.C., Higgins, C.T., and Bezore, S.P., 1981, Reconnaissance geothermal resource assessment of 40 sites in California - Part of the third year report, 1980-81, of the U.S. Department of Energy - California State-Coupled Program for reservoir assessment and confirmation: California Division of Mines and Geology. Open-File Report 82-4SAC, Report for U.S. Department of Energy, Contract No. DE-FG03-80SF 10855, 237 p.

"The report presents geological, geochemical, and historical data for low- and moderate-temperature geothermal sites located throughout California."

Majmundar, H.H., Publication in 1982. Technical Map of the Geothermal Resources of California: California Division of Mines and Geology, Geologic Data Map Series, Map no. 5, scale 1:750,000.

"A 4 1/2 by 5 foot, 7-color map of California with more than 600 geothermal wells and springs annotated. In addition to temperature data, the map pesents information on water chemistry including some mineral concentrations and water chemical type. An accompanying explanatory text contains many tables and maps."

Martin, R.C., Higgins, C.T., and Olmstead, D., 1980, Resource assessment of low- and moderate-temperature geothermal waters in California - Report of the first year, 1978-79. of the U.S. Department of Energy - California State-Coupled Program for reservoir assessment and confirmation: California Division of Mines and Geology, Report for U.S. Department of Energy Contract No. EW-78-S-07-1739, 188 p.

"The report is a compilation of California State wide low- and moderate-temperature geothermal resource data. The geothermal resources of Mono Basin, the South Bay Area of San Diego County. Paso Robles and the Southern Coast Ranges, and Bridgeport-Western Bodie Hill Region are presented in detail." 
Taylor, G.C., Bacon, C.F., Chapman, R.H., Chase, G.W., and Majmundar, H.H., 1981. Drilling Addendum to resource assessment of low- and moderate-temperature geothermal waters in Calistoga, Napa County, California - Report of the second year, 1979-80, of the U.S. Department of Energy - California State-Coupled Program for reservoir assessment and confirmation: California Division of Mines and Geology, Addendum to Open-File Report 81-13SAC, Report for U.S. Department of Energy, Contract No. DE-FG03-79ET27035, 73 p.

"The addendum presents the results and conclusions of the CDMG exploratory drilling program at Calistoga, California. The report includes geologic drill logs, geochemistry data, cross-sections, correlations of various investigative techniques, and geologic and hydrologic interpretations."

Youngs, L.G., Bacon, C.F., Chapman, R.H., Chase, G.W., Higgins, C.T., Majmundar, H.H., and Taylor, G.C., 1980, Resource assessment of low- and moderate-temperature geothermal waters in Calistoga, Napa County, California Report of the second year, 1979-80, of the U.S. Department of Energy - California State-Coupled Program for reservoir assessment and confirmation: California Division of Mines and Geology, Open-File Report 81-13SAC, Report for U.S. Department of Energy, Contract No. DE-FG03-79ET27035, 168 p.

"The report presents the data and results of a detailed scientific geothermal reservoir investigation of the Calistoga, California area. Methodology, history, geology, geophysical investigations, shallow and moderately deep hole temperature surveys, hydrology. geochemistry, seismicity, exploratory drilling, and reservoir evaluation are addressed in the report."

Youngs, L.G., Bezore, S.P., Chapman, R.H., and Chase, G.W., 1981, Resource investigation of low- and moderate-temperature geothermal areas in San Bernardino, California - Part of the third year report, 1980-81, of the U.S. Department of Energy California State-Coupled Program for reservoir assessment and confirmation: California Division of Mines and Geology, Open-File Report 82-11SAC, Report for U.S. Department of Energy, Contract No. DE-FG03-80SF 10855, 242 p.

\begin{abstract}
"The report presents the data and results of a detailed scientific geothermal reservoir investigation of the San Bernardino, California area. Geothermal historical development, geology, geochemistry, geophysical investigations, temperature surveys, hydrology. seismicity, and geothermal reservoir evaluations are addressed in the report."
\end{abstract}

Youngs, L.G., Chapman, R.H., Chase, G.W., Bezore, S.P., and Majmundar, H.H., publication in 1982. Investigation of low-temperature geothermal resources in the Sonoma Valley area, California - Part of the fourth year report, 1981-82, of the U.S. Department of Energy - California State-Coupled Program for reservoir assessment and confirmation: California Division of Mines and Geology, Open-File Report Report for U.S. Department of Energy, Contract No. DE-FGO3-81SF 10855 . p.

"The report presents the data and results of a detailed scientific geothermal reservoir investigation of the Sonoma Valley area, California. Historical geothermal development, geology. geochemistry, geophysical surveys, temperature surveys, hydrology, and geothermal reservoir characteristics are discussed in the report." 


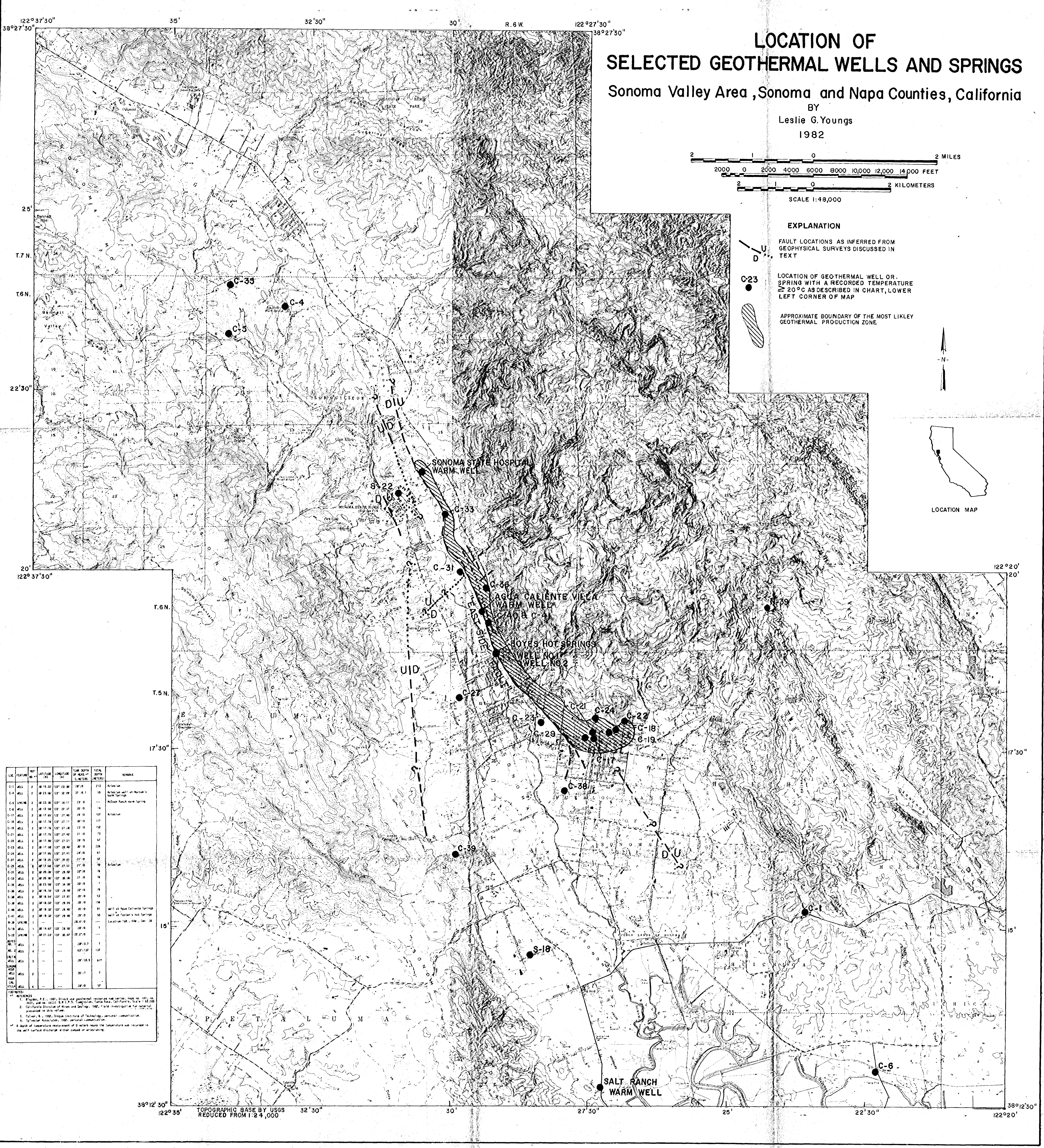





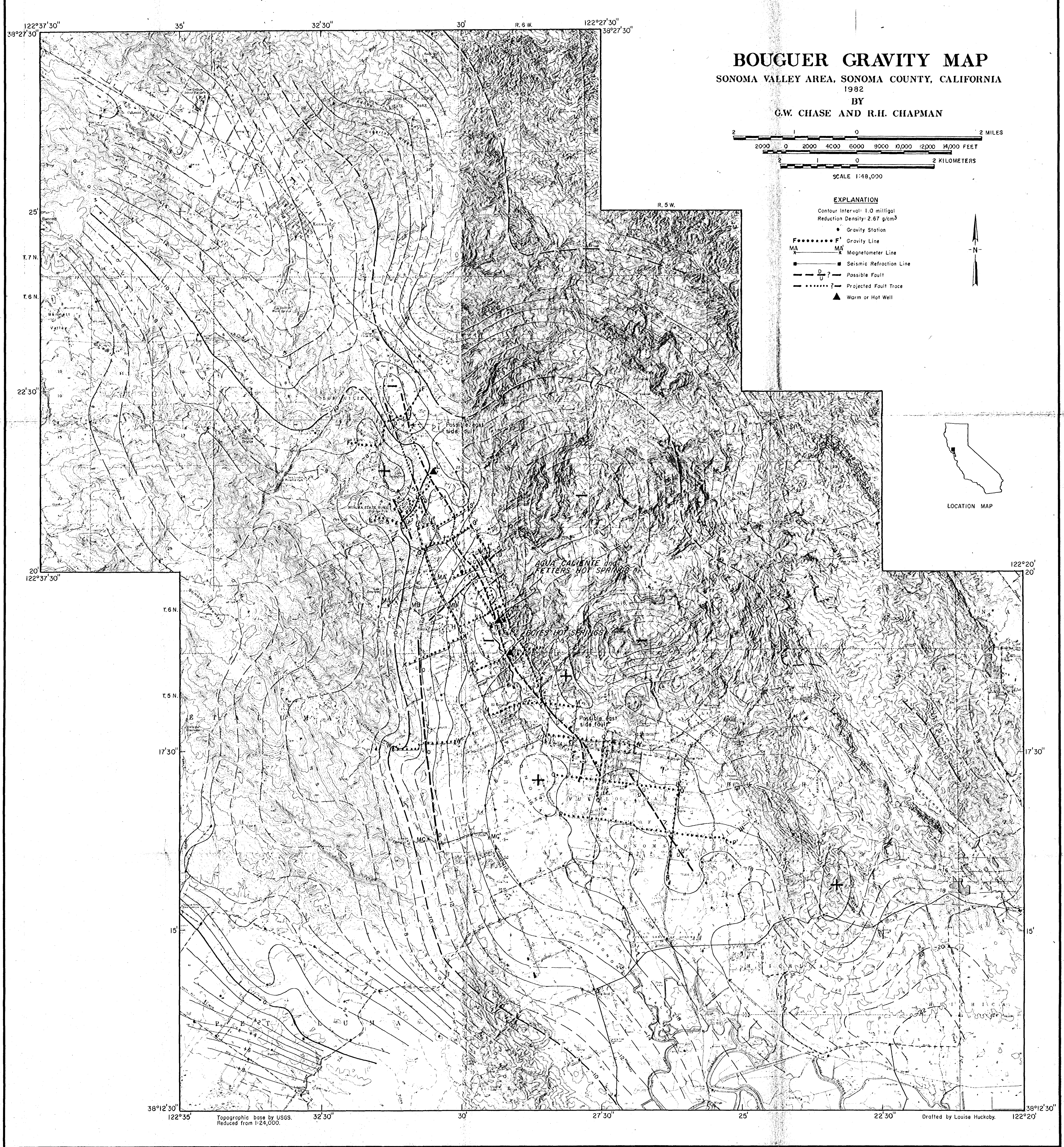




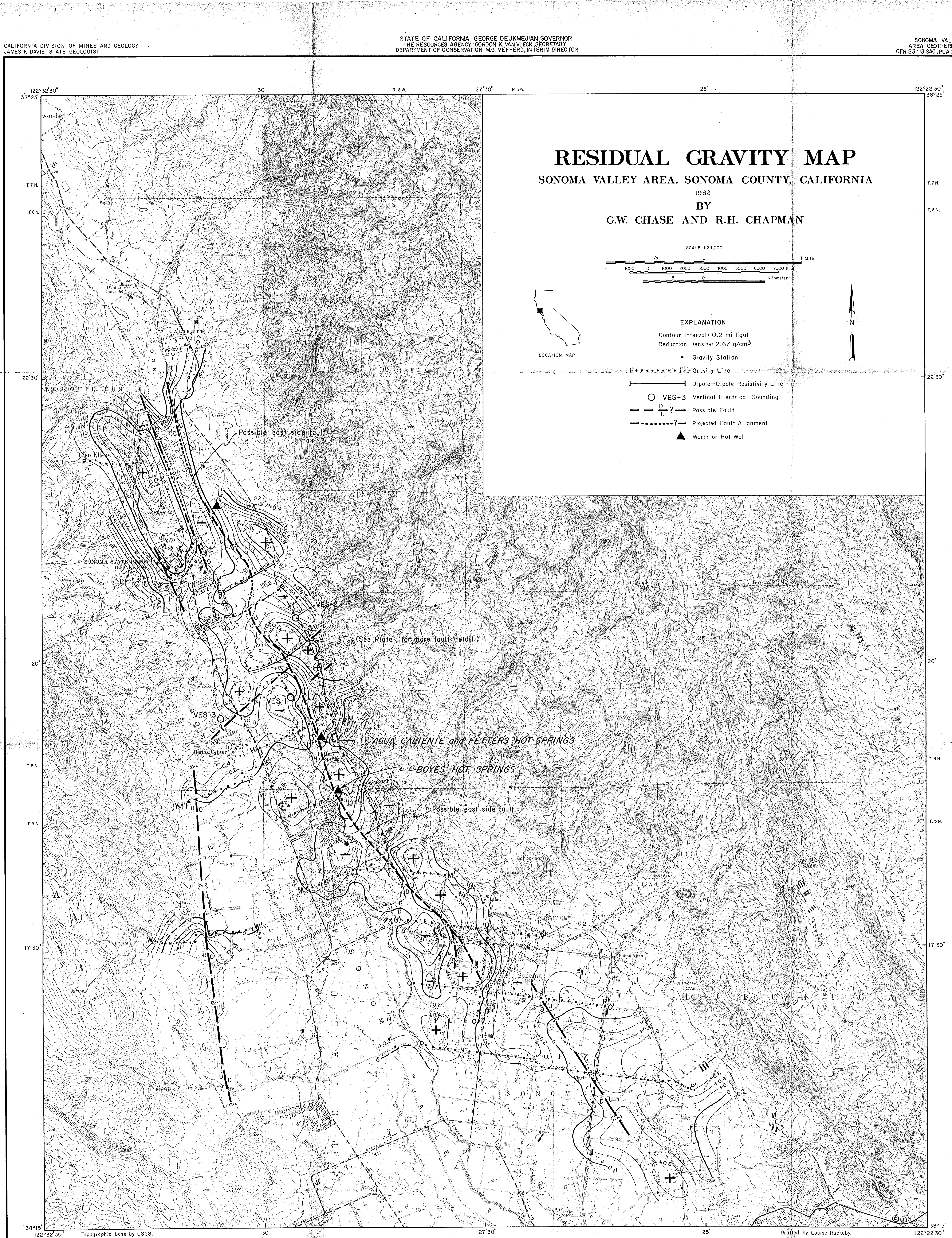




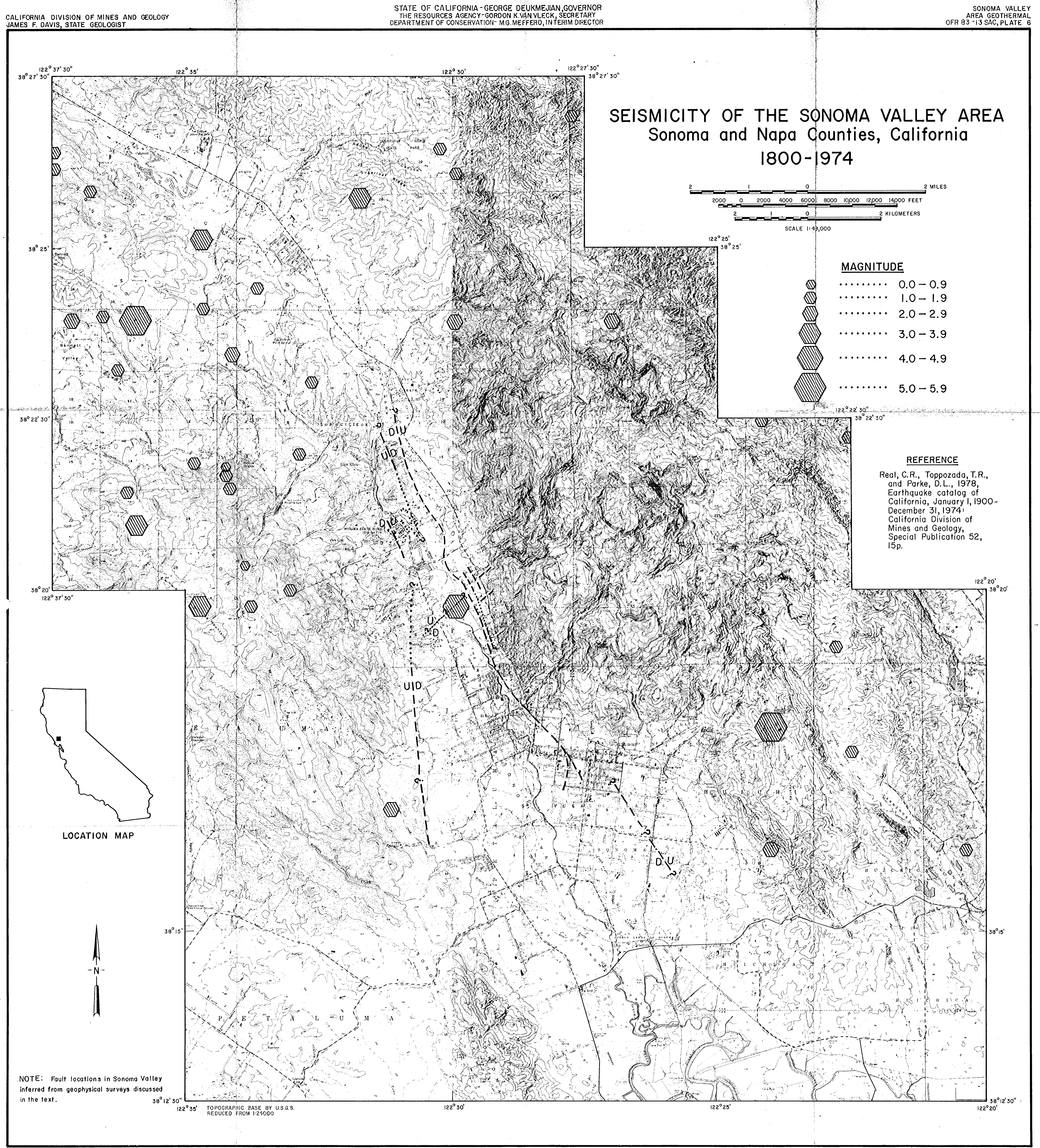




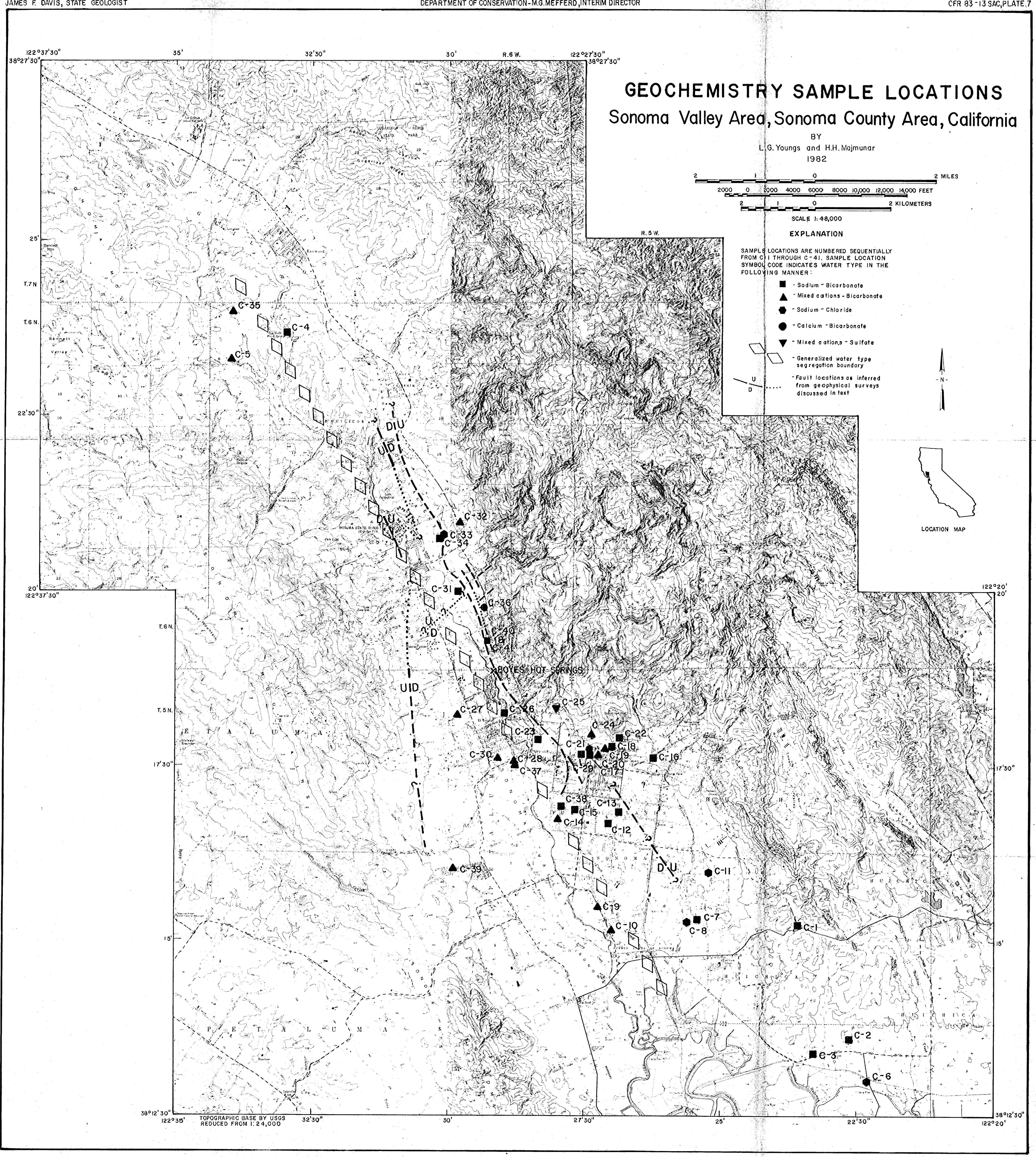




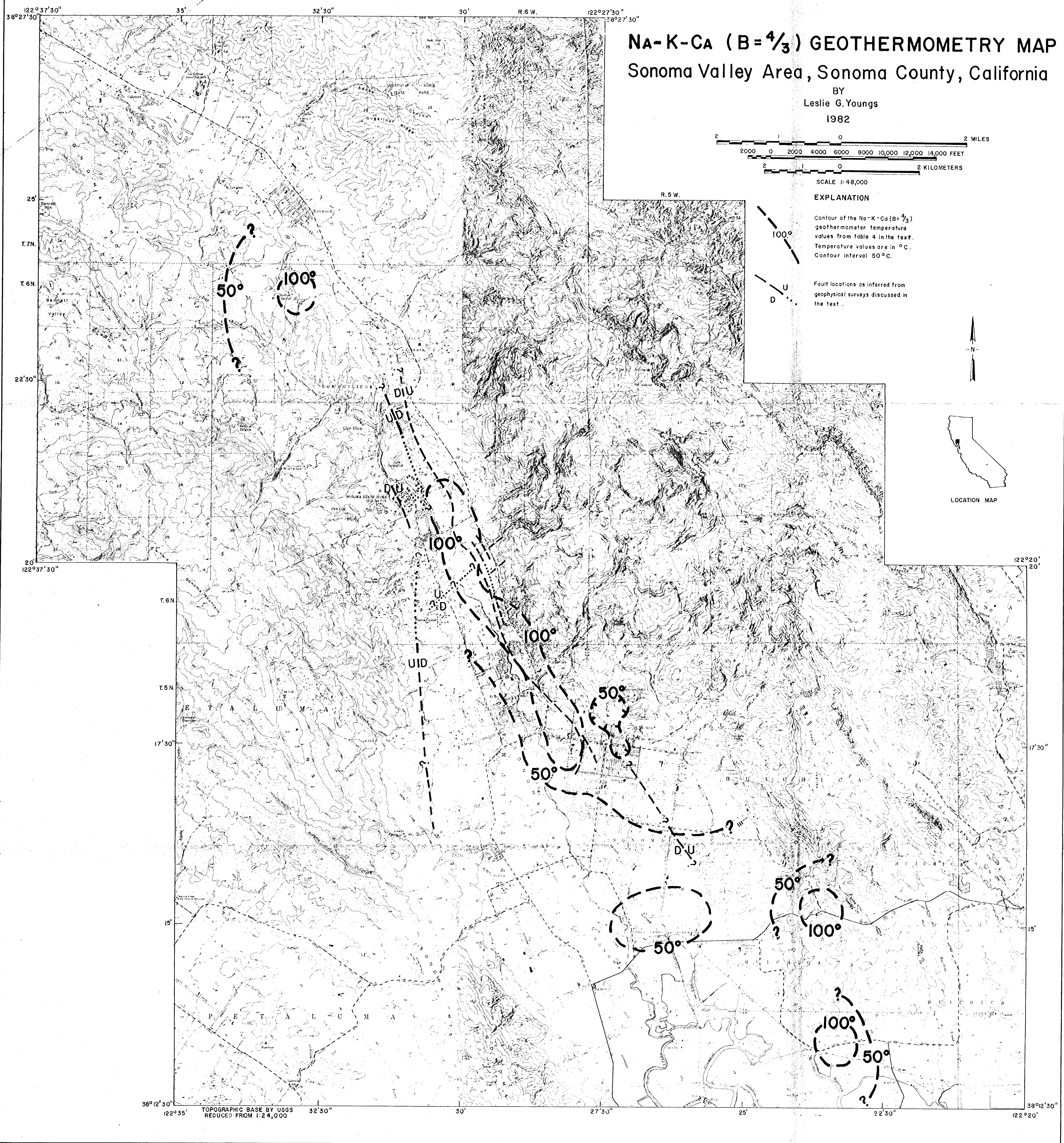




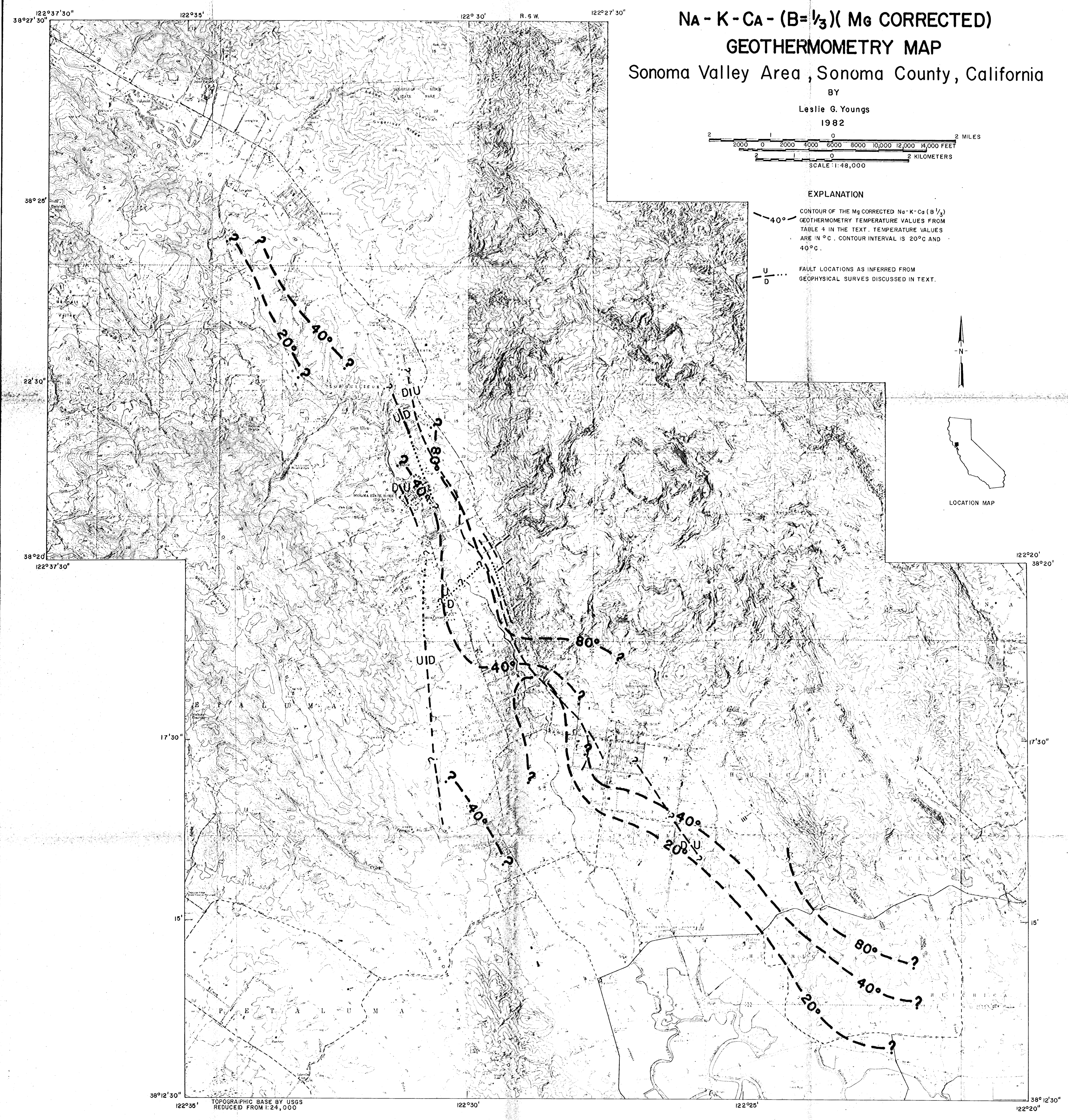

